VIGILÂNCIA SANITÁRIA DA FLUORETAÇÃO DAS ÁGUAS

DE ABASTECIMENTO PÚBLICO NO

MUNICÍPIO DE SÃO PAULO, BRASIL, NO PERÍODO 1990-1999

PAULO CAPEL NARVAI

São Paulo

2001 


\section{VIGILÂNCIA SANITÁRIA DA FLUORETAÇÃO DAS ÁGUAS \\ DE ABASTECIMENTO PÚBLICO NO \\ MUNICÍPIO DE SÃO PAULO, BRASIL, NO PERÍODO 1990-1999}

Tese apresentada à Faculdade de Saúde Pública da Universidade de São Paulo para concorrer ao título de Livre Docente.

Autor: PAULO CAPEL NARVAI

São Paulo

2001 
Para Raquel e Julia. 
Para David Capistrano da Costa Filho (in memoriam) que, por ter sabido doar o melhor de suas qualidades à luta pela conquista da saúde e cidadania para todos os brasileiros foi, e segue sendo, fonte de estímulo, motivação, aprendizado e compromisso com os proletários e despossuídos. 
AGRADECIMENTO

A todos os profissionais de saúde que participaram da organização e manutenção do pioneiro sistema municipal de vigilância sanitária da fluoretação das águas em São Paulo. 


\section{RESUMO}

Narvai PC. Vigilância sanitária da fluoretação das águas de abastecimento público no município de São Paulo, Brasil, no período 1990-1999. São Paulo, 2001 [Tese de Livre Docência - Faculdade de Saúde Pública da Universidade de São Paulo].

A eficácia preventiva da fluoretação das águas de abastecimento público depende da continuidade da aplicação desta medida e da manutenção de níveis adequados de flúor. As empresas de saneamento fazem controle operacional quando adicionam flúor às águas. Entretanto, faz-se necessário que além desse controle sejam montados sistemas de vigilância baseados no princípio do heterocontrole. No município de São Paulo, SP, Brasil, um sistema com essa característica foi inaugurado em 1990. A presente investigação descreve este sistema e apresenta resultados para o período 1990-1999. Material e Método. O estudo baseou-se em dados dos relatórios anuais publicados pela Secretaria Municipal de Saúde de São Paulo. Foram analisados dados relativos ao período 1990-1999, classificando-se as amostras, segundo o teor de flúor, em aceitáveis (teor de $F$ entre 0,6 e 0,8 ppm) ou inaceitáveis (teores abaixo de 0,6 ppm $\mathrm{F}$ ou acima de 0,8 ppm F). Os pontos de coleta de amostras foram classificados em adequados e inadequados. Resultados. Observou-se que a porcentagem de amostras aceitáveis foi sempre igual ou superior a $80 \%$. A porcentagem de locais adequados, contudo, variou de 56\% a 96\%. Entretanto, no período entre 1993 e 1996 a porcentagem de locais para os quais não se obteve informação aumentou de $11 \%$ para $43 \%$. Conclusão. A população teria estado exposta a níveis adequados de flúor nas águas de abastecimento público no período 1990-1999. Mas a elevada porcentagem de locais sem informação entre 1993 e 1996 e a ausência de informações sobre alterações relevantes no desempenho do sistema de vigilância, tanto para pior quanto para melhor, ameaçam-Ihe a credibilidade.

\section{PALAVRAS-CHAVE}

Flúor; Fluoretação da água; Vigilância sanitária; Heterocontrole; Vigilância da fluoretação. 


\begin{abstract}
Narvai PC. Health surveillance of drinking water fluoridation in the City of São Paulo, Brazil, in the period 1990-1999. São Paulo, 2001 [Thesis School of Public Health of University of São Paulo].
\end{abstract}

Effectiveness of water fluoridation depends on continuous and adequate levels of fluoride. Water suppliers companies have permanent control of the operational process. However, this is not enough to assure standard procedures and health authorities should establish a surveillance system based on the heterocontrol concept. A heterocontrol-based water fluoridation system was launched in the city of São Paulo, Brazil, in 1990. This thesis describes the system and shows the main results for the period 1990-1999. Materials and Method. Data from annual reports published by the local health authority in São Paulo were analysed. Water samples were classified as acceptable (from 0.6 to $0.8 \mathrm{ppm} F$ ) or unacceptable (less than 0.6 or above $0.8 \mathrm{ppm} \mathrm{F}$ ). Sites where samples were collected were classified as adequate or inadequate. Results. The percentage of acceptable samples was always $80 \%$ or above. However, percentage of adequate sites varied from $56 \%$ to $96 \%$. Sites with no information increased from $11 \%$ to $43 \%$ between 1993 and 1996. Conclusion. Adequate levels of added fluoride in the water supply were reported in São Paulo between 1990 and 1999. On the other hand, the high percentage of sites with no available data between 1993 and 1996 and the lack of information on relevant changes in the fluoride surveillance system may affect the system reliability.

\title{
KEYWORDS
}

Fluoride; Water fluoridation; Health surveillance; Heterocontrol; Fluoride surveillance. 


\section{ÍNDICE}

Página

1. INTRODUÇÃO

2. BASES TEÓRICAS 4

2.1. Flúor 4

2.2. Água Fluoretada 6

2.3. Fluoretação da Água 8

2.4. Vigilância Sanitária 14

2.5. Controle da Fluoretação 25

2.5.1. Controle Operacional 26

2.5.2. Heterocontrole 29

3. O CONTEXTO DA INTERVENÇÃO 31

3.1. Município de São Paulo 31

3.2. Breve Histórico da Fluoretação da Água em São Paulo 36

3.3. Política de Saúde no Município no Período 1990-1999 42

4. OBjetivos 49

5. Material e MÉtodo 50

5.1. O Sistema Municipal de Vigilância da Fluoretação 50

5.2. Classificação das Amostras e dos Locais 54

5.3. Dados

6. Resultados 56

6.1. Teor de Flúor na Amostra 56

6.2. Condição do Local 81

6.3. Valores Aberrantes 123

$\begin{array}{ll}\text { 7. DISCUSSÃO } & 124\end{array}$

8. CONSIDERAÇÕES FINAIS 133

9. REFERÊNCIAS BIBLIOGRÁFICAS 135

$\begin{array}{ll}\text { ANEXOS } & 150\end{array}$ 


\section{ÍNDICE DE TABELAS, QUADROS E FIGURAS}

\section{NúMERO E TÍTULO DA TABELA}

PÁGINA

1. Evolução da fluoretação das águas de abastecimento público no Brasil, no período 1953-1996

2. Capitais estaduais brasileiras que não fluoretam as águas de abastecimento público, população e cobertura do serviço de água, em 1996

3. Classificação das amostras de águas de abastecimento público segundo o teor de flúor. São Paulo, SP, Brasil, 1990

4. Classificação das amostras de águas de abastecimento público segundo o teor de flúor. São Paulo, SP, Brasil, 1991

5. Classificação das amostras de águas de abastecimento público segundo o teor de flúor. São Paulo, SP, Brasil, 1992

6. Classificação das amostras de águas de abastecimento público segundo o teor de flúor. São Paulo, SP, Brasil, 1993

7. Classificação das amostras de águas de abastecimento público segundo o teor de flúor. São Paulo, SP, Brasil, 1994

8. Classificação das amostras de águas de abastecimento público segundo o teor de flúor. São Paulo, SP, Brasil, 1995

9. Classificação das amostras de águas de abastecimento público segundo o teor de flúor. São Paulo, SP, Brasil, 1996

10. Classificação das amostras de águas de abastecimento público segundo o teor de flúor. São Paulo, SP, Brasil, 1997

11. Classificação das amostras de águas de abastecimento público segundo o teor de flúor. São Paulo, SP, Brasil, 1998

12. Classificação das amostras de águas de abastecimento público segundo o teor de flúor. São Paulo, SP, Brasil, 1999

13. Teores de flúor (em ppm) identificados em amostras de água de abastecimento público. São Paulo, SP, Brasil, 1990-1999

14. Teores de flúor (em ppm) identificados em amostras de água de abastecimento público. São Paulo, SP, Brasil, 1990

15. Teores de flúor (em ppm) identificados em amostras de água de abastecimento público. São Paulo, SP, Brasil, 1991

16. Teores de flúor (em ppm) identificados em amostras de água de abastecimento público. São Paulo, SP, Brasil, 1992 
17. Teores de flúor (em ppm) identificados em amostras de água de abastecimento público. São Paulo, SP, Brasil, 1993

18. Teores de flúor (em ppm) identificados em amostras de água de abastecimento público. São Paulo, SP, Brasil, 1994

19. Teores de flúor (em ppm) identificados em amostras de água de abastecimento público. São Paulo, SP, Brasil, 1995

20. Teores de flúor (em ppm) identificados em amostras de água de abastecimento público. São Paulo, SP, Brasil, 1996

21. Teores de flúor (em ppm) identificados em amostras de água de abastecimento público. São Paulo, SP, Brasil, 1997

22. Teores de flúor (em ppm) identificados em amostras de água de abastecimento público. São Paulo, SP, Brasil, 1998

23. Teores de flúor (em ppm) identificados em amostras de água de abastecimento público. São Paulo, SP, Brasil, 1999

24. Teores de flúor (em ppm) identificados em amostras de água de abastecimento público nos meses de janeiro. São Paulo, SP, Brasil, 1990-1999

25. Teores de flúor (em ppm) identificados em amostras de água de abastecimento público nos meses de fevereiro. São Paulo, SP, Brasil, 1990-1999

26. Teores de flúor (em ppm) identificados em amostras de água de abastecimento público nos meses de março. São Paulo, SP, Brasil, 1990-1999

27. Teores de flúor (em ppm) identificados em amostras de água de abastecimento público nos meses de abril. São Paulo, SP, Brasil, 1990-1999

28. Teores de flúor (em ppm) identificados em amostras de água de abastecimento público nos meses de maio. São Paulo, SP, Brasil, 1990-1999

29. Teores de flúor (em ppm) identificados em amostras de água de abastecimento público nos meses de junho. São Paulo, SP, Brasil, 1990-1999

30. Teores de flúor (em ppm) identificados em amostras de água de abastecimento público nos meses de julho. São Paulo, SP, Brasil, 1990-1999

31. Teores de flúor (em ppm) identificados em amostras de água de abastecimento público nos meses de agosto. São Paulo, SP, Brasil, 1990-1999 
32. Teores de flúor (em ppm) identificados em amostras de água de abastecimento público nos meses de setembro. São Paulo, SP, Brasil, 1990-1999

33. Teores de flúor (em ppm) identificados em amostras de água de abastecimento público nos meses de outubro. São Paulo, SP, Brasil, 1990-1999

34. Teores de flúor (em ppm) identificados em amostras de água de abastecimento público nos meses de novembro. São Paulo, SP, Brasil, 1990-1999

35. Teores de flúor (em ppm) identificados em amostras de água de abastecimento público nos meses de dezembro. São Paulo, SP, Brasil, 1990-1999

36. Classificação dos locais segundo o teor de flúor nas águas de abastecimento público. São Paulo, SP, Brasil, 1990

37. Classificação dos locais segundo o teor de flúor nas águas de abastecimento público. São Paulo, SP, Brasil, 1991

38. Classificação dos locais segundo o teor de flúor nas águas de abastecimento público. São Paulo, SP, Brasil, 1992

39. Classificação dos locais segundo o teor de flúor nas águas de abastecimento público. São Paulo, SP, Brasil, 1993

40. Classificação dos locais segundo o teor de flúor nas águas de abastecimento público. São Paulo, SP, Brasil, 1994

41. Classificação dos locais segundo o teor de flúor nas águas de abastecimento público. São Paulo, SP, Brasil, 1995

42. Classificação dos locais segundo o teor de flúor nas águas de abastecimento público. São Paulo, SP, Brasil, 1996

43. Classificação dos locais segundo o teor de flúor nas águas de abastecimento público. São Paulo, SP, Brasil, 1997

44. Classificação dos locais segundo o teor de flúor nas águas de abastecimento público. São Paulo, SP, Brasil, 1998

45. Classificação dos locais segundo o teor de flúor nas águas de abastecimento público. São Paulo, SP, Brasil, 1999

46. Valores aberrantes de flúor detectados em amostras de água de abastecimento público no município de São Paulo, no período 1990-1999 
1. Locais de coleta de água do sistema municipal de vigilância sanitária da fluoretação das águas, segundo o número do ponto

e a Administração Regional de Saúde. São Paulo, SP, 1990-1999

2. Classificação das amostras de água Segundo o teor de flúor. Município de São Paulo, SP, 1990-1999

\section{NÚMERO E TítULO dA FIGURA}

PÁGINA

1. Condições das amostras quanto à fluoretação. São Paulo, 1990-1999

2. Condições dos locais quanto à fluoretação. São Paulo, 1990-1999

3. Teores de flúor (em ppm) em águas coletadas no PAM J.B. Magaldi. São Paulo, SP, 1990-1999

4. Teores de flúor (em ppm) em águas coletadas no PAM Cambuci. São Paulo, SP, 1990-1999

5. Teores de flúor (em ppm) em águas coletadas no Hospital Menino Jesus. São Paulo, SP, 1990-1999

6. Teores de flúor (em ppm) em águas coletadas na Clínica Humaitá. São Paulo, SP, 1990-1999

7. Teores de flúor (em ppm) em águas coletadas na EMPG Infante D. Henrique. São Paulo, SP, 1990-1999

8. Teores de flúor (em ppm) em águas coletadas no PS Barra Funda. São Paulo, SP, 1990-1999

9. Teores de flúor (em ppm) em águas coletadas no PAM Vila Romana. São Paulo, SP, 1990-1999

10. Teores de flúor (em ppm) em águas coletadas na EMPG Dilermando D. Santos. São Paulo, SP, 1990-1999

11. Teores de flúor (em ppm) em águas coletadas no PAM Vila Nova Jaguaré. São Paulo, SP, 1990-1999

12. Teores de flúor (em ppm) em águas coletadas na UBS Jardim d'Abril. São Paulo, SP, 1990-1999

13. Teores de flúor (em ppm) em águas coletadas na UBS São Jorge. São Paulo, SP, 1990-1999

14. Teores de flúor (em ppm) em águas coletadas na UBS Jardim Jaqueline. São Paulo, SP, 1990-1999

15. Teores de flúor (em ppm) em águas coletadas no PAM Joaquim 
Rossini. São Paulo, SP, 1990-1999

16. Teores de flúor (em ppm) em águas coletadas no PAM Dr. Luiz E. Mazzoni. São Paulo, SP, 1990-1999

17. Teores de flúor (em ppm) em águas coletadas no PAM Dr. Geraldo S. Ferreira. São Paulo, SP, 1990-1999

18. Teores de flúor (em ppm) em águas coletadas no PAM Teotônio Vilela. São Paulo, SP, 1990-1999

19. Teores de flúor (em ppm) em águas coletadas na UBS Jardim Elba. São Paulo, SP, 1990-1999

20. Teores de flúor (em ppm) em águas coletadas na UBS H. Morbin Jr. São Paulo, SP, 1990-1999

21. Teores de flúor (em ppm) em águas coletadas na UBS Vila Guarani. São Paulo, SP, 1990-1999

22. Teores de flúor (em ppm) em águas coletadas no PAM Jardim São Francisco. São Paulo, SP, 1990-1999

23. Teores de flúor (em ppm) em águas coletadas na UBS Santa Terezinha. São Paulo, SP, 1990-1999

24. Teores de flúor (em ppm) em águas coletadas no PAM Jardim Itapema. São Paulo, SP, 1990-1999

25. Teores de flúor (em ppm) em águas coletadas no PAM Pe. José de Anchieta. São Paulo, SP, 1990-1999

26. Teores de flúor (em ppm) em águas coletadas no PAM Pe. Manoel da Nóbrega. São Paulo, SP, 1990-1999

27. Teores de flúor (em ppm) em águas coletadas no PAM Castro Alves. São Paulo, SP, 1990-1999

28. Teores de flúor (em ppm) em águas coletadas no PAM N. S. do Carmo. São Paulo, SP, 1990-1999

29. Teores de flúor (em ppm) em águas coletadas no PAM Cidade Líder. São Paulo, SP, 1990-1999

30. Teores de flúor (em ppm) em águas coletadas no PAM José Bonifácio II. São Paulo, SP, 1990-1999

31. Teores de flúor (em ppm) em águas coletadas no PAM Vila Santana. São Paulo, SP, 1990-1999

32. Teores de flúor (em ppm) em águas coletadas no PAM Jardim Tietê. São Paulo, SP, 1990-1999

33. Teores de flúor (em ppm) em águas coletadas no PAM Vila Cisper. São Paulo, SP, 1990-1999

34. Teores de flúor (em ppm) em águas coletadas no PAM Jardim Helena. São Paulo, SP, 1990-1999 
35. Teores de flúor (em ppm) em águas coletadas no PAM Ponte Rasa. São Paulo, SP, 1990-1999

36. Teores de flúor (em ppm) em águas coletadas no PAM Jardim Maia. São Paulo, SP, 1990-1999

37. Teores de flúor (em ppm) em águas coletadas na UBS Vila Ramos. São Paulo, SP, 1990-1999

38. Teores de flúor (em ppm) em águas coletadas na UBS Vila Jacuí. São Paulo, SP, 1990-1999

39. Teores de flúor (em ppm) em águas coletadas no PAM Parque Novo Mundo. São Paulo, SP, 1990-1999

40. Teores de flúor (em ppm) em águas coletadas no PAM Vila Nova Galvão. São Paulo, SP, 1990-1999

41. Teores de flúor (em ppm) em águas coletadas no PAM Joaquim A. Eirado. São Paulo, SP, 1990-1999

42. Teores de flúor (em ppm) em águas coletadas no PAM Carombé. São Paulo, SP, 1990-1999

43. Teores de flúor (em ppm) em águas coletadas no PAM Freguesia do Ó. São Paulo, SP, 1990-1999

44. Teores de flúor (em ppm) em águas coletadas no PAM D.

Mariquinha Sciacia. São Paulo, SP, 1990-1999

45. Teores de flúor (em ppm) em águas coletadas no PS Perus. São Paulo, SP, 1990-1999

46. Teores de flúor (em ppm) em águas coletadas no PAM Elísio Teixeira Leite. São Paulo, SP, 1990-1999

47. Teores de flúor (em ppm) em águas coletadas na UBS Jardim Ipanema. São Paulo, SP, 1990-1999

48. Teores de flúor (em ppm) em águas coletadas no PAM Vila Jaguara. São Paulo, SP, 1990-1999

49. Teores de flúor (em ppm) em águas coletadas no PAM Moinho Velho. São Paulo, SP, 1990-1999

50. Teores de flúor (em ppm) em águas coletadas no PAM Jardim Cidade Pirituba. São Paulo, SP, 1990-1999

51. Teores de flúor (em ppm) em águas coletadas na UBS Parelheiros. São Paulo, SP, 1990-1999

52. Teores de flúor (em ppm) em águas coletadas no PAM Chácara Santo Antonio. São Paulo, SP, 1990-1999

53. Teores de flúor (em ppm) em águas coletadas no PAM Vila Guacuri. São Paulo, SP, 1990-1999

54. Teores de flúor (em ppm) em águas coletadas no PAM Veleiros. São 
Paulo, SP, 1990-1999

55. Teores de flúor (em ppm) em águas coletadas no PAM Jardim Eliana. São Paulo, SP, 1990-1999

56. Teores de flúor (em ppm) em águas coletadas no PAM Jardim Mirna. São Paulo, SP, 1990-1999

57. Teores de flúor (em ppm) em águas coletadas no PAM Jardim São Bento. São Paulo, SP, 1990-1999

58. Teores de flúor (em ppm) em águas coletadas na UBS Jardim Marcelo. São Paulo, SP, 1990-1999

59. Teores de flúor (em ppm) em águas coletadas no PAM Campo Limpo. São Paulo, SP, 1990-1999

60. Teores de flúor (em ppm) em águas coletadas na UBS Jardim Angela. São Paulo, SP, 1990-1999

61. Teores de flúor (em ppm) em águas coletadas no PAM Jardim Tomás. São Paulo, SP, 1990-1999

62. Teores de flúor (em ppm) em águas coletadas no PAM Jardim Herculano. São Paulo, SP, 1990-1999

63. Teores de flúor (em ppm) em águas coletadas na UBS Parque Anhanguera. São Paulo, SP, 1990-1999

64. Teores de flúor (em ppm) em águas coletadas na UBS Dr. Carlos Muniz. São Paulo, SP, 1990-1999

65. Teores de flúor (em ppm) em águas coletadas na UBS Dr. Emílio S. Oliveira. São Paulo, SP, 1990-1999

66. Teores de flúor (em ppm) obtidos mensalmente em águas da região do Jardim d'Abril. São Paulo, SP, 1990-1999

67. Teores de flúor (em ppm) obtidos mensalmente em águas da região da Vila Jacuí. São Paulo, SP, 1990-1999

68. Teores de flúor (em ppm) obtidos mensalmente em águas da região do Jardim Angela. São Paulo, SP, 1990-1999

69. Teores de flúor (em ppm) obtidos mensalmente em águas da região de Perus. São Paulo, SP, 1990-1999

70. Teores de flúor (em ppm) obtidos mensalmente em águas da região da Freguesia do Ó. São Paulo, SP, 1990-1999

71. Teores de flúor (em ppm) obtidos mensalmente em águas da região da Bela Vista. São Paulo, SP, 1990-1999 


\section{LISTA DE SIGLAS, SÍMBOLOS, FÓRMULAS E ABREVIATURAS}

\begin{tabular}{|c|c|}
\hline ADA & - American Dental Association \\
\hline ANVISA & - Agência Nacional de Vigilância Sanitária \\
\hline APCD & - Associação Paulista de Cirurgiões-Dentistas \\
\hline APEDEMA & $\begin{array}{l}\text { - Assembléia Permanente das Entidades de Defesa do Meio } \\
\text { Ambiente de São Paulo }\end{array}$ \\
\hline ARS & - Administração Regional de Saúde \\
\hline art. & - Artigo \\
\hline $\mathrm{CaF}_{2}$ & - Fluoreto de cálcio \\
\hline CDC & - Centro de Controle e Prevenção de Doenças \\
\hline ceo-d & $\begin{array}{l}\text { - Índice de dentes decíduos cariados, com extração indicada e } \\
\text { obturados }\end{array}$ \\
\hline CETESB & - Companhia Estadual de Tecnologia e Saneamento Básico \\
\hline CNS & - Conferência Nacional de Saúde \\
\hline CNSB & - Conferência Nacional de Saúde Bucal \\
\hline $\mathrm{CPO}$ & - Índice de dentes permanentes cariados, perdidos e obturados \\
\hline CPO-D & - Índice de dentes permanentes cariados, perdidos e obturados \\
\hline CROSP & - Conselho Regional de Odontologia de São Paulo \\
\hline DOM & - Diário Oficial do Município de São Paulo \\
\hline DS & - Distrito de Saúde \\
\hline GECOF & - Grupo Estadual de Controle da Fluoretação \\
\hline EMPG & - Escola Municipal de Primeiro Grau \\
\hline ENATESPO & $\begin{array}{l}\text { - Encontro Nacional de Administradores e Técnicos do Serviço } \\
\text { Público Odontológico }\end{array}$ \\
\hline ES & - Estado do Espírito Santo, Brasil \\
\hline et al. & - E colaborador(es) \\
\hline ETA & - Estação de Tratamento de Água \\
\hline EUA & - Estados Unidos da América \\
\hline $\mathrm{F}$ & - Flúor \\
\hline FAPESP & - Fundação de Amparo à Pesquisa do Estado de São Paulo \\
\hline FSP & - Faculdade de Saúde Pública \\
\hline $\mathrm{km}^{2}$ & - Quilômetros quadrados \\
\hline I & - Litro \\
\hline $\mathrm{m}^{3}$ & - Metros cúbicos \\
\hline $\mathrm{mg}$ & - Miligrama \\
\hline
\end{tabular}




\begin{tabular}{|c|c|}
\hline MG & - Estado de Minas Gerais, Brasil \\
\hline $\mathrm{N}$ & - Número \\
\hline $\mathrm{n}^{\circ}$ & - Número \\
\hline$n$ & - Número de elementos amostrais \\
\hline OMS & - Organização Mundial da Saúde \\
\hline OPAS & - Organização Pan-Americana de Saúde \\
\hline PAM & - Posto de Assistência Médica \\
\hline PAS & - Plano de Atendimento à Saúde \\
\hline p.ex. & - Por exemplo \\
\hline ppm & - Partes por milhão \\
\hline PR & - Estado do Paraná, Brasil \\
\hline $\mathrm{R} \$$ & - Real (moeda nacional do Brasil em 2001) \\
\hline Resolução CNS & - Resolução do Conselho Nacional de Saúde \\
\hline Resolução SS & - Resolução do Secretário de Estado da Saúde de São Paulo \\
\hline RS & - Estado do Rio Grande do Sul, Brasil \\
\hline SABESP & - Companhia de Saneamento Básico do Estado de São Paulo \\
\hline SC & - Estado de Santa Catarina, Brasil \\
\hline SESP & - Fundação Serviços de Saúde Pública \\
\hline SES-SP & - Secretaria de Estado da Saúde de São Paulo \\
\hline SHS & - Secretaria de Higiene e Saúde \\
\hline SIMS & - Sistema Integrado Municipal de Saúde \\
\hline SINDSEP & - Sindicato dos Servidores Públicos Municipais de São Paulo \\
\hline SMS-SP & - Secretaria Municipal da Saúde de São Paulo \\
\hline SP & - Estado de São Paulo, Brasil \\
\hline SUS & - Sistema Único de Saúde \\
\hline UBS & - Unidade Básica de Saúde \\
\hline UPAFAI & - União Paulista Antifluoretação Artificial Inadequada \\
\hline US\$ & - Dólar (moeda nacional dos Estados Unidos da América em 2001) \\
\hline USP & - Universidade de São Paulo \\
\hline WHO & - World Health Organization \\
\hline$\%$ & - Porcentagem \\
\hline$\S$ & - Parágrafo \\
\hline $3 \mathrm{Ca}_{3}\left(\mathrm{PO}_{4}\right)_{2} \mathrm{CaF}_{2}$ & - Fluorapatita \\
\hline $3 \mathrm{NaF} \mathrm{Al} \mathrm{F} 3$ & - Fluoreto duplo de alumínio e sódio \\
\hline
\end{tabular}


Do povo oprimido nas filas, nas vilas, favelas

Da força da grana que ergue e destrói coisas belas Da feia fumaça que sobe apagando as estrelas Eu vejo surgir teus poetas, de campos e espaços (...)

Pan-américas de Áfricas utópicas

Mais possível novo Quilombo de Zumbi

Caetano Veloso, em Sampa 


\section{INTRODUÇÃO}

A cárie dentária ainda é, em termos de saúde pública, o principal problema de saúde bucal dos habitantes de São Paulo. O índice CPO, empregado para medir o ataque da doença em dentes permanentes registrou, entre escolares, um importante declínio no período de 1986 a 1996: na idadeíndice de 12 anos seu valor evoluiu de 6,5 em 1886 para 2,1 em 1996 (NARVAl e col. 2000). Tais valores indicam que se em 1986 os escolares dessa idade apresentavam, em média, 6,5 dentes permanentes atacados pela doença, em 1996 apenas 2,1 dentes, em média, tinham sido atingidos. Tratase de uma redução expressiva: 4,4 dentes em média, correspondendo a 67,7\% de redução. Apesar disso, foi constatado em 1996 que 60,2\% dos escolares dessa idade-índice haviam sido atingidos pela cárie em algum momento de suas vidas, afetando pelo menos um dente permanente - em $26,3 \%$ a doença atingia quatro ou mais dentes (NARVAl e col. 2000).

Tais números indicam que, embora com menor magnitude, a cárie dentária ainda é um importante problema de saúde pública no município.

Dentre os fatores possivelmente envolvidos no mencionado declínio tem sido aceito que o principal é a fluoretação das águas de abastecimento público (iniciada em 1985) uma vez que os efeitos preventivos do flúor, sobejamente conhecidos (MURRAY 1992; BASTOS e col. 1993), são maiores quando a água é empregada como veículo, em ações de saúde pública (VIEGAS e col. 1987). 
O Centro de Controle e Prevenção de Doenças (CDC), dos Estados Unidos, admite que o poder preventivo da água fluoretada é de $40 \%$ a $70 \%$ em crianças - reduzindo também a perda de dentes em adultos em porcentagem que varia de $40 \%$ a $60 \%$ (CDC 1999).

Entretanto, desde que teve início a fluoretação das águas no município, autoridades públicas e especialistas de saúde pública e da área odontológica expressaram, em diversas oportunidades, preocupação quanto à continuidade da medida, sobretudo em função de dúvidas quanto à disponibilidade de insumos (ácido fluorsilícico, por exemplo, produto empregado pela SABESP — Companhia de Saneamento Básico do Estado de São Paulo) e à adequação dos procedimentos técnicos de modo a que a água contivesse, permanentemente, $0,7 \mathrm{ppm}$ de flúor - teor considerado adequado para 0 município. Estas preocupações relacionam-se com uma importante característica da fluoretação da água: para produzir os efeitos preventivos é indispensável que os teores adequados sejam mantidos permanentemente. Havendo interrupção, permanente ou temporária, desaparece o benefício. Isto também ocorre se os teores ficarem abaixo do recomendado (LEMKE e col. 1970; JORDAN 1962).

Há, ainda, um outro inconveniente: se os teores estiverem acima do recomendado pode haver malefício, produzindo-se fluorose dentária em crianças cujos dentes estiverem em formação durante o período em que o teor estiver elevado (PINTO 1993).

Por estas razões, tão importante quanto manter ou adicionar flúor às águas de abastecimento público, é controlar todo o processo para que a água 
contenha permanentemente teores adequados do produto. Mas se é indispensável que a empresa produtora da água controle o processo de tratamento e distribuição do produto, assegurando-lhe a qualidade exigida pela legislação, isto não é suficiente. São necessárias, também, ações no âmbito da vigilância sanitária.

Neste estudo, aborda-se o sistema de vigilância sanitária da fluoretação das águas de abastecimento público criado em 1990 no município de São Paulo, SP, Brasil, analisando-se o seu desempenho no período 1990-1999. 


\section{BASES TEÓRICAS}

\subsection{FLÚOR}

O flúor é o $13^{\circ}$ elemento mais abundante na natureza - e, também, o mais eletronegativo dos halogênios, grupo que inclui ainda o cloro, o bromo e o iodo. Com grande capacidade de reagir com outros elementos químicos e formar compostos orgânicos e inorgânicos, o flúor está presente no ar, no solo e nas águas. Sua concentração varia largamente (MURRAY 1986): geralmente é de 0,05 a 1,90 microgramas no ar mas em determinados ambientes de fábricas pode atingir até $1,4 \mathrm{mg} \mathrm{F} / \mathrm{m}^{3}$; no solo encontra-se em geral de 20 a 500 partes por milhão (ppm) mas há registro de até 8.500 ppm; e na água do mar é de cerca de 1,0 ppm, variando entre 0,8 e 1,4 ppm. Em águas, a maior concentração de flúor foi detectada no Lago Nakuru, no Quênia: 2.800 ppm. Concentrações acima de 10 ppm foram registradas em regiões do México e Estados Unidos e em diversos países da África (NIKIFORUK 1985; MURRAY 1986).

O primeiro estudo abrangente feito no Brasil sobre flúor, seu teor na água e em outras fontes e suas implicações para a saúde humana, foi publicado em 1950 por Yaro Ribeiro Gandra, professor do Departamento de Nutrição da então Faculdade de Higiene e Saúde Pública da Universidade de São Paulo (GANDRA 1950). Fazendo considerações sobre a distribuição do flúor na natureza afirmou:

"O flúor acha-se distribuído amplamente na natureza, embora, exceptuadas as jazidas de minerais dêste elemento, geralmente em quantidade diminutas. Não se encontra livre na natureza e está mais 
concentrado em regiões fosfáticas, de alumínio e cinzas vulcânicas onde entra na formação de filões de jazidas minerais das quais as mais conhecidas são as de criolita, que é o fluoreto duplo de alumínio e sódio (3NaF Al $\left.\mathrm{F}_{3}\right)$; fluorita, também chamada espatoflúor e que é o fluoreto de cálcio $\left(\mathrm{CaF}_{2}\right)$; a fluoropatita de fórmula $3 \mathrm{Ca}_{3}\left(\mathrm{PO}_{4}\right)_{2} \mathrm{CaF}_{2}$. O flúor é encontrado nas águas em maior quantidade quando estas, passando através de jazidas minerais dêste elemento, dêle se enriquecem. As águas profundas de poços artesianos são geralmente mais ricas. O flúor é encontrado tanto no reino animal, como no vegetal, embora em pequeníssimas quantidades. Nos animais, existe nos ossos e nos dentes, como já havia sido demonstrado em 1801 por Morichini e mais tarde por Arnold e Breckhus, onde desempenha papel importante, acumulando-se principalmente no esmalte e dentina. McClure estudando a riqueza de flúor nos alimentos encontrou-o em maiores quantidades nos peixes, ovos e também no leite variando muito pouco neste, quando a taxa ingerida pelo animal produtor é aumentada (...) No reino vegetal, predomina geralmente nas gramíneas e McClure achou-o em quantidades maiores no chá, na aveia, pão de centeio, espinafre etc." (GANDRA 1950). Tais considerações foram confirmadas posteriormente pela Organização Mundial da Saúde e outros pesquisadores (OMS 1972; WHO 1984; MURRAY 1992; CURY 1992). 


\section{2. ÁGUA FLUORETADA}

McKay foi o primeiro a relacionar o flúor à cárie dentária ao observar que em Colorado Springs [Estados Unidos da América] a maioria das crianças apresentavam "esmalte manchado" (mottled enamel) e muito baixa prevalência de cárie.

"Dentes manchados" - fluorose dentária, sabe-se hoje — já haviam sido observados e descritos por outros autores, como Morichini em 1805 e Eager em 1901 (OMS, 1972).

McKay percebeu que as crianças de certas áreas não apresentavam dentes manchados mas, nelas, a prevalência de cárie era tão alta quanto em outras regiões dos Estados Unidos. Aventou então a hipótese de que algum elemento químico existente na água seria responsável pela diferença (MCKAY e BLACK 1916; MCKAY 1928). A formulação dessa hipótese fez com que se iniciassem estudos sobre a água em algumas localidades onde a população apresentava "dentes manchados". Sua hipótese seria confirmada por CHURCHILL (1931): foram encontrados altos níveis de flúor (2,0 a 12,0ppm).

A partir desses achados, o rumo das investigações foi o de estabelecer uma concentração tal de flúor nas águas que fosse capaz de produzir o máximo benefício de prevenção de cáries e o mínimo tolerável de fluorose dentária nas populações expostas.

Dean, que propôs a denominação "fluorose dentária" para os "dentes manchados", chegou ao valor de $1 \mathrm{ppm}$, admitindo pequenas variações segundo as características ambientais, sobretudo temperatura, após comparar 
dados secundários sobre prevalência de fluorose dentária e cárie em 26 estados dos EUA (CDC 1999; FORNI 2000).

O próprio Dean realizou também estudos sobre a relação flúor-cáriefluorose em 21 cidades nos estados do Colorado, Illinois, Indiana e Ohio (DEAN 1938 apud VIEGAS 1961).

Firmou-se então, com base em estudos científicos, a tese de que adequada concentração de flúor na água $(0,7$ ppm, p.ex., na maioria do território brasileiro) é capaz de reduzir a prevalência de cárie em aproximadamente $60 \%$. Esse "poder preventivo" do flúor seria confirmado em centenas de estudos realizados em todo o mundo (CHAVES, 1977).

O significado dessa descoberta levou COX (1939) a propor que a American Dental Association - ADA recomendasse oficialmente a fluoretação da água. Isso viria a ocorrer 11 anos depois, em 1950, quando já estavam bem consolidados os resultados das primeiras experiências de fluoretação controlada (ADA, 1951).

A Organização Mundial da Saúde (OMS), a Organização Pan-americana da Saúde (OPAS), o Ministério da Saúde (MS) e todas as entidades nacionais representativas da área odontológica no Brasil recomendam a fluoretação das águas de abastecimento público nos locais onde há indicação técnica para aplicar a medida (VIEGAS 1989; MINISTÉRIO DA SAÚDE 1999). Segundo o Ministério da Saúde brasileiro:

"a medida é recomendada por mais de 150 organizações de ciência e saúde, incluindo a Federação Dentária Internacional, a Associação 
Internacional de Pesquisa Odontológica, a OMS e a OPAS [sendo que] programas de fluoretação da água têm sido implementados em aproximadamente 39 países, atingindo mais de 200 milhões de pessoas. Acrescente-se a isto um adicional estimado de outras 40 milhões que ingerem água naturalmente fluoretada." (MINISTÉRIO DA SAÚDE 1999).

\subsection{FLUORETAÇÃO DA ÁGUA}

A adição de flúor às águas de abastecimento público, como estratégia de saúde pública para prevenir a cárie dentária, teve início com três estudos pilotos em 1945 nos Estados Unidos (Grand Rapids, Michigan; e Newburgh, Estado de New York) e no Canadá (Brantford, Ontario). Para cada uma dessas cidades foram definidas "cidades controles" para avaliação dos resultados, a saber: Muskegon e Kingston (Estados Unidos) e Sarnia (Canadá). Cidades cujas águas eram naturalmente fluoretadas foram também incluídas na pesquisa: Aurora (1,2 ppm) para a dupla Grand Rapids-Muskegon, e Stratford (1,2 ppm) para a dupla Brantford-Sarnia.

Essas experiências pioneiras visavam à comprovação da segurança e praticabilidade do procedimento e à eficácia da fluoretação artificial como método de massa para prevenção de cárie. Tais investigações foram ampla e profundamente monitoradas em seus aspectos médicos e de engenharia tendo ficado exaustivamente demonstrado, já nos anos 50 , a eficácia e segurança sanitária da medida. Os coeficientes de mortalidade por câncer, diabetes, 
doenças cardiovasculares, hepáticas e renais, entre outras, foram avaliados em todas essas cidades (WHO 1984).

Outras características como o baixo custo relativo e a abrangência do método preventivo foram comprovadas e vários programas de fluoretação da água logo tiveram início em várias regiões dos Estados Unidos e do Canadá (CDC 1999; MURRAY 1992).

O flúor tem sido, desde então, objeto de milhares de investigações científicas em todo o mundo. Em pesquisa na base de dados Medline em 15/01/2001, utilizando o unitermo "fluoride" foram identificados 26.248 trabalhos científicos (a lista correspondente equivalia a 1.313 páginas). Com o unitermo "fluorine" foi possível identificar 8.143 trabalhos (408 páginas). Segundo a OMS os conhecimentos disponíveis permitem utilizá-lo com toda segurança em saúde pública (WHO 1984).

Segundo censo realizado pelo CDC, em 1992 nos Estados Unidos, a fluoretação das águas atingia 62\% da população (aproximadamente 144 milhões de pessoas) com acesso à água de abastecimento público — incluindo cerca de 10 milhões de pessoas abastecidas por 3.784 sistemas de abastecimento naturalmente fluoretados, em 1.924 localidades. Considerada a população total do país a porcentagem se reduzia para 56\% (CDC, 1999).

O CDC define fluoretação da água como sendo a adição deliberada do elemento natural flúor na água de beber em conformidade com as recomendações científicas e odontológicas (CDC 1995). 
A primeira menção de que se tem notícia recomendando oficialmente a adição de flúor à água de abastecimento público no Brasil foi feita pelo $\mathrm{X}$ Congresso Brasileiro de Higiene, realizado em Belo Horizonte - MG, em outubro de 1952. Mas ROSSI e OLIVEIRA (1947) assinalaram que:

"em São Paulo já foi verificada a pequena quantidade de flúor nas águas de abastecimento e foi também proposto [grifo do autor] o acréscimo de quantidades que perfaçam a normalidade. Infelizmente, verificamos nenhuma providência das autoridades sobre o assunto e nossas águas continuam apresentando a insignificante proporção de 0,2 a 0,4 ppm de F (...) proporemos a dosagem e controle das quantidades de $F$ não só em S. Paulo, mas em todo o Brasil."

Baixo Guandu, no Espírito Santo, foi a primeira cidade brasileira a ter suas águas de abastecimento público fluoretadas. O processo teve início em 31 de outubro de 1953, sob responsabilidade da Fundação Serviços de Saúde Pública - SESP, exatamente um ano após a recomendação do X Congresso Brasileiro de Higiene. O teor ótimo de flúor na água foi estabelecido em 0,8 ppm - o teor naturalmente existente era 0,15 ppm (CHAVES e col. 1953).

Em 12 de dezembro de 1956, Marília, no Estado de São Paulo, iniciou a fluoretação das suas águas (BUENDIA 1984).

A terceira cidade brasileira a fluoretar suas águas foi Taquara, no Rio Grande do Sul (RS), em outubro de 1957. O RS foi o primeiro Estado brasileiro onde se estabeleceu, mediante lei, em 18 de junho de 1957, a obrigatoriedade da fluoretação das águas de abastecimento público (PIRES FILHO e col. 1989). 
A primeira capital estadual a ter suas águas fluoretadas no Brasil foi Curitiba, PR, em 1958 - e também a quarta cidade brasileira (MUNIZ, 1968 apud AMARANTE e col. 1993).

Nos anos 80 houve uma grande expansão da fluoretação das águas no Brasil, decorrente de decisão governamental federal de apoiar financeiramente iniciativas nessa área (VIANNA e col. 1983). Mas consequência, também - e, talvez, sobretudo - da eleição direta de governadores e o surgimento de novos coordenadores estaduais de saúde bucal, muitos dos quais empenhados em reorientar as políticas públicas nesse setor.

Entre outros, o caso do Estado de São Paulo é indicativo do sentido daquelas mudanças: celebração de dezenas de convênios para municipalização da assistência; estímulo ao trabalho em clínicas modulares, fixas e transportáveis; incorporação de pessoal auxiliar e formação de equipes de saúde bucal; e desenvolvimento de sistemas de prevenção baseados na fluoretação das águas.

Apesar de certa oposição (AMARAL 1985; 1986; NARVAI 1986; CHAIB 1987; LICHTIG 1987), foi feita a fluoretação das águas dos municípios da região metropolitana de São Paulo, incluindo a Capital (CROSP 1985).

Desde 1974, a fluoretação das águas é obrigatória no Brasil, onde exista Estação de Tratamento de Água (ETA). Tal obrigatoriedade foi estabelecida pela Lei Federal 6.050, de 24/5/74 (BRASIL 1974), regulamentada pelo Decreto 76.872, de 22/12/75 (BRASIL 1976). 
O estabelecimento de normas legais sobre fluoretação de águas foi decisivo para esclarecer dúvidas, dar sustentação ao processo de fluoretação em todo o país e facilitar a alocação de recursos a tais empreendimentos. Uma noção da evolução da fluoretação das águas de abastecimento público no Brasil, a partir de 1953, pode ser vista na Tabela 1. Apesar da expansão desta medida, várias capitais estaduais ainda não adicionam flúor à água servida à população (Tabela 2).

Segundo o Ministério da Saúde "aproximadamente 65 milhões de brasileiros estão sendo atualmente beneficiados pela agregação de flúor ao tratamento da água com resultados comprovados de eficiência do método." (MINISTÉRIO DA SAÚDE 1999).

Estima-se que o custo per capita/ano da fluoretação no Brasil seja da ordem de $R \$ 1,00$ ou aproximadamente US $\$ 0,50$. Segundo BURT (1989) o custo médio nos Estados Unidos fica em torno de US\$ 0,51. É a melhor relação custo-benefício, dentre todas as atividades específicas da prática odontológica. Manter um indivíduo beneficiado pela fluoretação da água ao longo de toda a sua vida custa o equivalente a uma única restauração dentária. 
Tabela 1. Evolução da fluoretação das águas de abastecimento público no Brasil, no período 1953-1996.

\begin{tabular}{|c|c|c|c|}
\hline \multirow[t]{2}{*}{ ANO } & \multirow[t]{2}{*}{ POPULAÇÃO } & \multicolumn{2}{|c|}{ POPULAÇÃO COM ÁGUA FLUORETADA } \\
\hline & & $\mathrm{N}$ & $\%$ \\
\hline 1953 & 56.593 .016 & 6.100 & 0,01 \\
\hline 1956 & 61.660 .772 & 56.100 & 0,09 \\
\hline 1958 & 65.288 .953 & 395.553 & 0,61 \\
\hline 1959 & 67.182 .332 & 505.456 & 0,75 \\
\hline 1961 & 72.053 .450 & 785.678 & 1,09 \\
\hline 1963 & 76.189 .381 & 1.369 .338 & 1,80 \\
\hline 1965 & 80.562 .718 & 1.558 .731 & 1,93 \\
\hline 1967 & 85.187 .088 & 1.738 .813 & 2,04 \\
\hline 1969 & 90.076 .902 & 2.500 .000 & 2,78 \\
\hline 1970 & 93.139 .037 & 2.930 .000 & 3,15 \\
\hline 1972 & 98.690 .200 & 3.339 .000 & 3,38 \\
\hline 1977 & 113.208 .500 & 10.772 .000 & 9,52 \\
\hline 1982 & 123.640 .593 & 25.757 .000 & 20,83 \\
\hline 1989 & 141.343 .519 & 60.003 .000 & 42,45 \\
\hline 1995 & 155.196.725 & 65.500 .000 & 42,20 \\
\hline
\end{tabular}

Fontes: GRINPLASTCH (1974), PINTO (1993), MINISTÉRIO DA SAÚDE. Área Técnica de Saúde Bucal (1999). 
Tabela 2. Capitais estaduais brasileiras que não fluoretam as águas de abastecimento público, população e cobertura do serviço de água, em 1996.

\begin{tabular}{ccc}
\hline CAPITAL & POPULAÇÃO & \% COM ÁGUA TRATADA \\
\hline Aracaju & 435.447 & 100,00 \\
Cuiabá & 462.739 & 100,00 \\
João Pessoa & 536.641 & 100,00 \\
Maceió & 688.856 & 88,88 \\
Manaus & 1.128 .175 & 95,07 \\
Natal & 658.298 & 89,43 \\
Porto Velho & 320.148 & 46,67 \\
Recife & 1.341 .910 & 97,53 \\
Salvador & 2.239 .226 & 90,08 \\
São Luiz & 758.982 & 100,00 \\
Teresina & 653.094 & 99,00 \\
\hline TOTAL & 18.447 .032 & - \\
\hline
\end{tabular}

Fonte: MINISTÉRIO DA SAÚDE. Área Técnica de Saúde Bucal (1999).

\subsection{VIGILÂNCIA SANITÁRIA}

A Vigilância Sanitária é um dos pilares da Saúde Pública. NASCIMENTO (1998) considera, entretanto, que no Brasil o sistema de vigilância sanitária vem se caracterizando:

"por uma ação meramente cartorial (centrada fundamentalmente no registro de produtos), que demonstra um poder fiscalizatório frágil, marcado pela incapacidade de coerção do Estado [resultado] de uma 
política implementada de forma consciente e planejada nos últimos anos, caracterizada por sucessivos cortes de investimento na vigilância, na falta de estímulo aos profissionais do setor e no desaparelhamento dos órgãos públicos ."

A Lei Federal 8.080, de 19/09/1990, define Vigilância Sanitária (artigo 6oㅡ, $\left.\mathrm{XI}, 1^{\circ}\right)$ como "um conjunto de ações capaz de eliminar, diminuir ou prevenir riscos à saúde e de intervir nos problemas sanitários decorrentes do meio ambiente, da produção e circulação de bens e da prestação de serviços de interesse da saúde." (BRASIL 1990).

Encontra-se na Constituição da República (parágrafo II do artigo 200) que compete ao Sistema Único de Saúde "executar as ações de vigilância sanitária (...)" (BRASIL 1988). Tal disposição legal atribui ao Estado, portanto, papel central na realização das ações de Vigilância Sanitária.

Além do parágrafo II, em outros parágrafos do mesmo artigo 200 da Constituição aparecem outras competências do SUS relacionadas direta ou indiretamente às ações de vigilância sanitária e ao assunto em tela:

"controlar e fiscalizar procedimentos, produtos e substâncias de interesse para a saúde e participar da produção de medicamentos, equipamentos, imunobiológicos, hemoderivados e outros insumos" (§ I); "participar da formulação da política e da execução das ações de saneamento básico" (§ IV); "fiscalizar e inspecionar alimentos, compreendido o controle de seu teor nutricional, bem como bebidas e águas para consumo humano" (§ VI); "participar do controle e 
fiscalização da produção, transporte, guarda e utilização de substâncias e produtos psicoativos, tóxicos e radioativos" (§ VII). (BRASIL 1988). Em São Paulo, a Constituição do Estado de São Paulo afirma, no artigo 223 que compete ao Sistema Único de Saúde, nos termos da lei:

"a identificação e o controle dos fatores determinantes e condicionantes da saúde individual e coletiva, mediante, especialmente ações referentes à: a) vigilância sanitária (...)”. (SÃO PAULO 1989).

A Lei Complementar no 791/95, de 09/03/1995, estabelece o Código de Saúde no Estado e estabelece (artigo 56) que:

"pela interdependência do seu conteúdo e do desenvolvimento de suas ações, a vigilância sanitária (...) [implica] compromisso solidário do Poder Público, do setor privado e da sociedade em geral na proteção e defesa da qualidade de vida"

E ainda que compete à direção estadual do SUS (artigo 15 e outros):

"colaborar com a União na execução da vigilância sanitária de portos, aeroportos e fronteiras (...); acompanhar, avaliar e divulgar os indicadores de morbidade, mortalidade e condições de risco ou agravo à saúde (...); estabelecer normas para o controle e a avaliação das ações e dos serviços de saúde, incluindo normas técnicas especiais de vigilância sanitária e vigilância epidemiológica $[e]$ coordenar e, em caráter complementar, executar ações e serviços de (...) vigilância sanitária (...) em articulação e integração com outros setores, dentre os quais os de saneamento básico, energia, planejamento urbano, obras públicas, agricultura e meio ambiente (...)”. (SÃO PAULO 1995). 


\subsubsection{VIGILÂNCIA SANITÁRIA E SAÚDE BUCAL}

Antes de abordar, mais especificamente, a atuação da Vigilância Sanitária na área de interesse da odontologia, convém uma menção ao próprio conceito de Vigilância Sanitária. Apresentando uma perspectiva bastante abrangente, COSTA (1999) afirma:

"Não obstante insuficientemente teorizada em termos doutrinários e conceituais, a Vigilância Sanitária (...) abarca e ultrapassa o conceito de poder de polícia ou - pelo desgaste deste termo - o equivalente ao poder atribuído pela sociedade ao Estado para interferir nas liberdades individuais em favor dos interesses públicos (...) Atuando diretamente no conjunto de bens materiais e imateriais, meios de circulação de bens e sobre o indivíduo em situação específica (...) e em aspectos do ambiente, a Vigilância Sanitária ocupa-se de riscos atuais ou potenciais - para preveni-los, diminui-los, eliminá-los ou reduzir efeitos previstos ao mínimo possível; atuando indiretamente, deve desenvolver atividades educativas e de informação à coletividade de pessoas, incluindo os produtores e prestadores de serviços e organizações sociais. A Vigilância também se ocupa da qualidade porque deve estabelecer meios para assegurá-la, deve verificá-la, monitorá-la, e articular-se com o desenvolvimento, em especial o científico e tecnológico, para obter elementos que contribuam na elevação de padrões técnicos, na realização ética e no aumento da qualidade de vida. Tendo por objeto essencial a proteção e defesa da saúde coletiva - para cujo alcance 
seus instrumentos se definem no processo social - a Vigilância Sanitária abarca direitos humanos chamados de primeira, de segunda e de terceira geração; isto é, direitos individuais — liberdade e direito à vida - direitos sociais de fruição individual e alcance coletivo — direito à saúde e à educação —, e direitos de titularidade coletiva — direito ao desenvolvimento, ao ambiente e à propriedade sobre o patrimônio comum da humanidade, abrangendo direitos das futuras gerações." [grifos no original].

A autora diz ainda que:

"A Vigilância Sanitária permaneceu muito tempo no país como um campo à margem da Saúde Pública, esquecido quanto à sua importância para a saúde da população. No contexto nacional de limitado desenvolvimento científico e tecnológico, e de atraso no processo de formação da cidadania, o desconhecimento ou a redução do valor da Vigilância Sanitária tem contribuído para o desinteresse dos meios acadêmicos em tomá-la como objeto de estudo." (COSTA 1999). EDUARDO e MIRANDA (1998) apresentam o seguinte resumo histórico da Vigilância Sanitária no Brasil:

"foram estruturadas, nos séculos XVIII e XIX, para evitar a propagação de doenças nos agrupamentos urbanos que estavam surgindo. A execução desta atividade exclusiva do Estado, por meio da polícia sanitária, tinha como finalidade observar o exercício de certas atividades profissionais, coibir o charlatanismo, fiscalizar embarcações, cemitérios e áreas de comércio de alimentos. No final do século XIX houve uma 
restruturação da vigilância sanitária impulsionada pelas descobertas nos campos da bacteriologia e terapêutico nos períodos que incluem a I e a II Grandes Guerras. Após a II Guerra Mundial, com o crescimento econômico, os movimentos de reorientação administrativa ampliaram as atribuições da vigilância sanitária no mesmo ritmo em que a base produtiva do País foi construída, bem como conferiram destaque ao planejamento centralizado e à participação intensiva da administração pública no esforço desenvolvimentista. A partir da década de oitenta, a crescente participação popular e de entidades representativas de diversos segmentos da sociedade no processo político moldaram a concepção vigente de vigilância sanitária, integrando, conforme preceito constitucional, o complexo de atividades concebidas para que o Estado cumpra o papel de guardião dos direitos do consumidor e provedor das condições de saúde da população."

Em 1999 o governo brasileiro, com a Lei oํ 9.782, de 25/01/1999, reestruturou o Sistema Nacional de Vigilância Sanitária e criou a Agência Nacional de Vigilância Sanitária (ANVISA), uma autarquia sob regime especial vinculada ao Ministério da Saúde e caracterizada como agência reguladora com independência administrativa, estabilidade dos dirigentes durante 0 período de mandato e autonomia financeira, cuja finalidade institucional é "promover a proteção da saúde da população por intermédio do controle sanitário da produção e da comercialização de produtos e serviços submetidos à vigilância sanitária, inclusive dos ambientes, dos processos, dos insumos e das tecnologias a eles relacionados. Além disso, a Agência exerce o controle 
de portos, aeroportos e fronteiras e a interlocução junto ao Ministério das Relações Exteriores e instituições estrangeiras para tratar de assuntos internacionais na área de vigilância sanitária." (ANVISA 2001).

Na área de saúde bucal, segundo NARVAI (1996b), "predominava no Brasil, até recentemente, um enfoque bastante limitado para as ações de vigilância sanitária. As atividades nessa área estiveram restritas, basicamente, à tradicional 'fiscalização do exercício profissional' com a ênfase colocada nos estabelecimentos de prestação de serviços odontológicos e, mais especificamente, nos aspectos relacionados à utilização de radiações ionizantes. A partir do início dos anos 80, coincidindo com a ampliação dos espaços democráticos no país e com a realização de eventos técnico-científicos reunindo profissionais da área com atuação nos serviços públicos, observa-se a inclusão de novos temas nas pautas de debates. A própria consolidação da estratégia de fluoretação das águas de abastecimento público para prevenção da cárie dentária passou a estimular discussões acerca dos aspectos de vigilância sanitária requeridos por essa medida. Por outro lado, aspectos relacionados à qualidade de produtos, tanto os de uso profissional quanto os de uso doméstico, começaram a ser objeto de maior preocupação por parte dos profissionais de saúde pública. As ações de vigilância sanitária em saúde bucal começavam a ter seu foco de atenção deslocado do consultório odontológico para o ambiente, considerado em sentido amplo. Ainda que a atuação continuasse 
restrita, pelo menos o debate teórico se abria às novas questões e as discussões passaram a contemplar também aspectos relativos ao ambiente (água), produtos de uso profissional (mercúrio e outros) e produtos de uso doméstico (pastas de dentes e escovas dentárias, por exemplo). Mas a prática da vigilância sanitária continuava centrada no consultório odontológico. Essa situação seria alterada no final dos anos 80 com a organização do sistema de vigilância sanitária da fluoretação das águas de abastecimento público no Município de São Paulo (início formal de operações a partir de janeiro de 1990) e com o aparecimento, em nível federal, de normas relativas à produção e comercialização de dentifrícios e colutórios (1989)."

NARVAI (1998) propõe que, no âmbito da saúde bucal coletiva e da área de atuação odontológica, as ações de Vigilância Sanitária abrangem três dimensões: "os estabelecimentos de prestação de serviços odontológicos, os produtos para higiene bucal, e os alimentos e bebidas".

O flúor é um elemento químico que, por estar presente em diversos produtos, como águas de abastecimento público, águas minerais, bebidas como chá preto e refrigerantes, em alimentos, e em alguns medicamentos e suplementos nutricionais, é de grande interesse para a Vigilância Sanitária (OMS 1972; MURRAY 1992; BASTOS e col. 1993; PINTO 1993; SANTORO 1997).

Em águas, o teor adequado de flúor (concentração ótima) varia principalmente em conformidade com a média das temperaturas máximas anuais em cada local (GALLAGAN e VERMILLION 1957). De modo geral, 
dentro de certos limites, quanto maior essa média, menor a quantidade de flúor; quanto menor a média, maior a quantidade do íon. Na maior parte do território do Estado de São Paulo o teor adequado é $0,7 \mathrm{mg}$ de flúor por litro d'água (ou 0,7 ppm) (SÃO PAULO 1995).

Mas flúor em excesso (acima de 0,8 ppm no Estado de São Paulo) pode - se o excesso perdurar por vários dias, semanas ou meses - produzir alterações na mineralização do esmalte dentário, levando a um quadro clínico conhecido como fluorose dentária. Ainda que numa importante revisão de pesquisas sobre eficácia e segurança da fluoretação o respeitado National Health and Medical Research Council, da Austrália, tenha concluído (AUSTRÁLIA 1991) que o flúor proveniente de dentifrícios corresponde a mais de $53 \%$ do total de flúor ingerido por crianças de até 2 anos, parte importante da quantidade total de flúor é ingerida através da água.

Com efeito, analisando as fontes e fatores que podem contribuir para uma exposição sistêmica a flúor, LIMA (2000) considerou que o limite de exposição que tem sido aceito, em termos de risco para fluorose dentária, oscila entre 0,05 e $0,07 \mathrm{mg} \mathrm{F} / \mathrm{kg} / \mathrm{dia}$. A pesquisadora observou que, nas condições em que sua pesquisa foi desenvolvida, "as crianças foram submetidas a uma dose total de flúor pela dieta+dentifrício superior ao limite." Entre as opções de: a) utilizar por escovação uma quantidade máxima de 0,3 g de dentifrício, mantendo a concentração convencional de 1.100 ppm F; b) reduzir a concentração do dentifrício para 600 ppm de flúor solúvel; e, c) reduzir a concentração de flúor da água para 0,3 ppm F, a autora concluiu "ser mais apropriada (...) a utilização de quantidades reduzidas de dentifrício." 
Para CHEDID (1999) "pequena quantidade de dentifrício utilizada na escova apresentaria o mesmo efeito anticariogênico em esmalte de dente decíduo que a quantidade convencional."

Assim, para que se possa utilizar com segurança produtos fluorados, é imprescindível o desenvolvimento de ações de vigilância sanitária sobre a quantidade de flúor existente nas águas para consumo humano, mantendo-a dentro dos limites estabelecidos.

Conforme mencionado anteriormente, a Lei Federal no 6.050 tornou obrigatória a fluoretação das águas de abastecimento público em todo o território brasileiro "onde houver estação de tratamento de água". O Decreto Federal 76.872 regulamentou a lei e a Portaria 635, de 26/12/1975, estabeleceu os padrões para operacionalização da medida (BRASIL 1976).

No Estado de São Paulo, a Resolução SS-250/95, de 15/08/95 estabelece que para os municípios do Estado de São Paulo as águas devem conter $0,7 \mathrm{mg}$ de flúor por litro (0,7 ppm). Segundo este documento, é aceitável variação no teor de flúor desde que oscile entre 0,6 a 0,8 mg/l (onde a média das temperaturas máximas diárias do ar, observadas durante um período mínimo de 1 ano, encontrar-se abaixo de 14,7 graus Celsius, o limite superior da variação é $1,0 \mathrm{mg} / \mathrm{l})$. Teor de flúor abaixo ou acima desse intervalo caracteriza a água como "fora do Padrão de Potabilidade" (SÃO PAULO 1995), portanto, inaceitável para consumo humano do ponto de vista da prevenção da cárie e da fluorose dentária.

A existência de dispositivos legais relacionados à fluoretação da água e ao seu controle contribuem para o uso adequado desse recurso preventivo. 
Quando instrumentos legais não existem a tendência é que a fluoretação não seja realizada. Comparando a situação entre os estados norte-americanos do Texas (sem legislação específica; $n=58$ cidades) e Dakota do Sul (com legislação específica, desde 1969; $n=75$ cidades), SHANNON (1980) observou que o teor médio de flúor nas águas foi de 0,56 ppm F (desvio padrão $=0,29)$ no Texas - onde o teor ótimo varia de 0,70 a 1,20 ppm F - e de 1,16 ppm $\mathrm{F}$ (desvio padrão $=0,36$ ) em Dakota do Sul - onde o teor ótimo varia de 0,90 a 1,70 ppm F. O teor de flúor na água foi medido, diariamente, durante 30 dias. Em Dakota do Sul apenas 10,7\% dos locais situaram-se abaixo de 0,70 ppm F; nenhum acima de 1,94 ppm F. No Texas, entretanto, dois terços dos locais situaram-se abaixo do limite inferior $(0,70 \mathrm{ppm} F)$ do teor ótimo para a região, evidenciando as dificuldades decorrentes da inexistência de instrumentos legais para controlar a fluoretação.

SHANNON (1980) relatou também que em outro estado norteamericano, o Tennessee, onde não havia norma legal relativa à fluoretação das águas, a Agência de Proteção Ambiental dos Estados Unidos analisou o teor de flúor nas águas de 119 sistemas de abastecimento registrados como fluoretados, a partir de amostra representativa $(n=24)$. Em apenas $12(50 \%)$ desses 24 sistemas o teor de flúor situava-se dentro dos limites definidos para o Estado (0,80 a 1,20 ppm F). 


\subsection{CONTROLE DA FLUORETAÇÃO}

A eficácia preventiva da fluoretação das águas de abastecimento público, em relação à cárie dentária, depende da continuidade da medida ao longo do tempo e da manutenção de teores adequados de flúor (MAIER 1971; OMS 1972; CDC 1999).

A interrupção permanente faz cessar os benefícios. A adição de quantidades insuficientes do produto torna a medida inócua; a adição de quantidades excessivas pode causar fluorose dentária (CHAVES e col. 1953). Ambas são conseqüências indesejáveis. Por essa razão precisam ser evitadas. Para isto é imprescindível que haja permanente controle da fluoretação.

Tal controle pode ser feito em pelo menos dois níveis:

a) o controle operacional, realizado pela empresa produtora da água, integrado ao conjunto de procedimentos de controle da operação, nas estações de tratamento de água (ETA) e/ou antes da distribuição para a rede no caso de água originada em poços, com o objetivo de garantir a qualidade do produto vendido à população; e,

b) heterocontrole, realizado pelo órgão de vigilância sanitária do poder executivo, com o objetivo de assegurar que o produto oferecido ao consumo da população atenda aos dispositivos legais e não apresente riscos à saúde humana. 


\subsubsection{CONTROLE OPERACIONAL}

A melhor maneira de evitar teores inadequados de flúor na água quando esta provém de uma estação de tratamento de água é o monitoramento periódico desse teor na própria ETA. Há sistemas, como os operados pela SABESP, em que esse controle é realizado diariamente a cada hora, durante as 24 horas.

Tal controle operacional, é pré-requisito à implementação segura da fluoretação e condição sine qua non para a eficácia da medida (CURY 1992).

KÜNZEL (1980) relatou aumento nos valores dos índices CPO-D e ceod, em localidade alemã, após interrupção da fluoretação das águas, destacando:

"a necessidade crucial de atribuir a mais alta prioridade aos aspectos tecnológicos da fluoretação da água. É essencial fazer o monitoramento freqüente e manter níveis ótimos de flúor. Em situações nas quais se constatar alterações desse nível ótimo, em decorrência de procedimentos inadequados, imprevistos ou avarias, medidas corretivas devem ser tomadas imediatamente, garantindo-se a manutenção do desempenho operacional."

Entretanto, pode ocorrer de o controle operacional ser falho.

SCHNEIDER FILHO e col. (1992) mencionam localidades "oficialmente fluoretadas", querendo com a expressão referir-se a cidades onde este procedimento não é de fato realizado mas o foi em algum momento no passado - e a informação de que há fluoretação permanece como algo oficial. 
Neste caso, as conseqüências têm importante impacto sobre a saúde da população.

No Brasil, VASCONCELLOS (1982) relatou um episódio de inocuidade da fluoretação em Araraquara, SP. A fluoretação teve início em 1963 e, através de uma pesquisa epidemiológica realizada em 1979, não foi possível confirmar a hipótese de que escolares nascidos e sempre residentes na cidade (expostos à água fluoretada) apresentariam valores menores para o índice CPO-D quando comparados com escolares não nascidos e/ou nem sempre residentes em Araraquara. Após analisar os dados do sistema de registro da companhia de abastecimento a autora concluiu que "os resultados obtidos (...) confirmam a descontinuidade na manutenção da concentração de flúor na água".

UCHÔA e SALIBA (1970) relataram presença de fluorose dentária em escolares de Pereira Barreto, SP, que estiveram expostos à água de abastecimento público com teores de flúor variando de 1,5 a 17,5 ppm F. Observaram que a água com elevado teor de flúor era proveniente de três poços profundos. Percebendo a importância de dar um sentido positivo ao teor inadequado de flúor nessas águas, Uchôa e Saliba recomendaram a construção de uma ETA na qual seria possível "proceder uma mistura da água proveniente dos poços com excesso de fluoretos [com] a água do rio Tietê (...) de maneira que a água a ser fornecida à população viesse a apresentar uma taxa de fluoretos de acordo com as recomendações técnicas, o que seria realmente bastante fácil, não haveria maiores despesas e o benefício da prevenção da cárie dental, incalculável." 
CAPELLA e col. (1989) descreveram episódio de fluorose dentária endêmica que acometeu a população de Cocal do Sul, SC, após ingestão, entre 1985 e 1988, de água oriunda de poço profundo contendo de 1,2 até 5,6 ppm de flúor. Os autores mencionaram também a omissão das autoridades da área de saneamento e a reação de lideranças comunitárias, "especialmente por mães professoras inconformadas com o problema que atingia seus filhos."

Há ainda, situações em que não se sabe o que, efetivamente, ocorre com a fluoretação uma vez que a única informação disponível é a fornecida pela empresa responsável pelo abastecimento de água. Esta é, aliás, a situação mais freqüente. Apenas para exemplificar tais situações, FERREIRA e col. (1999) mencionam que em Vitória, ES, "a concentração de flúor na água (...) nunca foi avaliada por um outro órgão que não fosse a instituição responsável pela fluoretação (...)".

Em 1987, a Secretaria de Estado da Saúde de São Paulo (SES-SP), reconhecendo a importância de o controle da fluoretação não ficar restrito ao controle da operação feito na ETA criou, através da Resolução SS-329, de 13/11/1987, um grupo interinstitucional encarregado de avaliar, entre outros aspectos da fluoretação, "o teor de fluoreto nas águas de abastecimento, medido em diferentes pontos da rede." (SÃO PAULO 1987). Também o Conselho Nacional de Saúde, através da Resolução CNS-142, de 17/11/1994, determinou que o órgão federal de vigilância sanitária "normatizará em 90 dias (...) os teores de flúor em ETAs e pontos da rede." (BRASIL 1994). Isto não ocorreu. 


\subsubsection{HETEROCONTROLE}

Entretanto, a questão do controle dos controladores, isto é, o controle das empresas encarregadas da fluoretação feito por outros interessados e, sobretudo, por parte das instituições responsáveis pela saúde pública, tem se revelado de difícil aceitação e implantação. BARROS e col. (1990) também destacaram que:

"em diferentes ocasiões (congressos, encontros, cursos, seminários etc.), profissionais têm relatado vivências, contatos pessoais, visitas a estações de tratamento de águas ou medições isoladas, verificando que a concentração de flúor não estaria sendo a adequada e/ou que a adição do sal estaria se processando sem a necessária continuidade”.

Analisando registros de controle operacional da fluoretação em Porto Alegre, RS, no período de setembro de 1975 a maio de 1988, os autores constataram que "as descontinuidades ocorreram de forma elevada" e que "os organismos envolvidos com a fluoretação em Porto Alegre não cumpriram a contento seus papéis de executar e controlar o processo." (BARROS e col. 1990).

NARVAI (1991) mencionou que "não deve haver descontinuidade da medida [e que] há, portanto, necessidade de permanente controle sobre os teores de flúor existentes nas águas, em diferentes pontos do sistema de distribuição." Isso decorre do fato de que "no Brasil não se controla a quantidade de flúor das nossas águas." (NARVAI 1980). 
A necessidade de desenvolver mecanismos de controle da fluoretação distintos do controle operacional fez surgir o conceito de heterocontrole (NARVAI 1980; 1993; 1996b). Para este autor:

"heterocontrole é o princípio segundo o qual se um bem ou serviço qualquer implica risco ou representa fator de proteção para a saúde pública então além do controle do produtor sobre o processo de produção, distribuição e consumo deve haver controle por parte das instituições do Estado." (NARVAI 2000). 


\section{O CONTEXTO DA INTERVENÇÃO}

A presente investigação trata de um processo de intervenção em Saúde Pública, no âmbito da Vigilância Sanitária, desenvolvido no município de São Paulo, Brasil, no período de 1990 a 1999. Desta forma, considera-se indispensável apresentar, ainda que em linhas gerais, algumas características do referido município de interesse para a compreensão do objeto, contextualizando-o. Aborda-se também, ainda que em linhas gerais, a política de saúde implementada no município no período 1990-1999, bem como faz-se um breve histórico do processo de fluoretação das águas de abastecimento público.

\subsection{MUNICÍPIO DE SÃO PAULO}

Com cerca de 10 milhões de habitantes, em 1999, São Paulo é a maior cidade da América do Sul e o principal polo econômico do Brasil. O município situa-se no Planalto de Piratininga, região leste do Estado de São Paulo, sudeste do país. Seus habitantes, que ocupam uma área territorial de 1.509 $\mathrm{km}^{2}$, apresentam características gerais de morbidade e mortalidade que configuram o que se vem denominando "transição epidemiológica", uma vez que padrões epidemiológicos típicos das regiões menos desenvolvidas do país coexistem com perfis de morbi-mortalidade que se assemelham aos de países desenvolvidos. O coeficiente de mortalidade infantil registrou, em 1999, 16,3 óbitos por mil nascidos vivos; mas varia desde cerca de 6 por mil, nos bairros mais ricos, até próximo de 25 por mil nas vilas mais pobres de bairros da periferia urbana. Por outro lado, o coeficiente de mortalidade decorrente de 
complicações no aparelho cardiovascular não difere significativamente do observado nas grandes metrópoles dos países desenvolvidos.

O teor de flúor que ocorre naturalmente nas águas do município foi registrado pela primeira vez por ARAUJO, em 1942 (GANDRA 1950). Utilizando o método de Sanchis - "com modificação do autor", segundo Gandra - Araujo "dosou o flúor em águas de quatro proveniências diversas, entre as que suprem a cidade de São Paulo e encontrou resultados que variaram de 0,2 a 0,4 ppm de flúor."

Em 1947, ROSSI e OLIVEIRA constataram a existência de valores oscilando entre 0,2 a 0,4 ppm $F$ - medidos com os recursos de sua época. Segundo Gandra, Campos (1948/1949), "usando o método de Willard e Winter com algumas modificações, analisou o teor de flúor de águas provenientes de 5 adutoras das que abastecem a cidade de São Paulo e obteve resultados bem mais baixos que Araujo, isto é, variando de 0,04 a 0,08 ppm." (GANDRA 1950).

O próprio Gandra incluiu, numa ampla pesquisa sobre teor de flúor em 1950 nas águas de 335 municípios do Estado de São Paulo, informações sobre as seguintes regiões da capital paulista (entre parênteses os respectivos valores encontrados em ppm F): Água Branca $(0,10)$, Araçá $(0,10)$, Avenida [sic] $(0,05)$, Chácara Flora $(0,10)$, Consolação $(0,10)$, Freguesia do Ó $(0,10)$, Moóca $(0,10)$, Penha $(0,15)$, Vila América $(0,10)$, Vila Deodoro $(0,10)$, Vila Mariana $(0,10)$ e Santana $(0,05)$.

Ao constatar a "pequena quantidade de flúor nas águas de abastecimento" de São Paulo, ROSSI e OLIVEIRA (1947) assinalaram que é 
"extremamente variável" o teor de flúor de acordo com as regiões brasileiras. Mas mencionaram acreditar que "no Brasil as quantidades de flúor nas águas são deficientes [e que nosso problema] talvez se restrinja à deficiência de flúor, mesmo porque não temos notícia de fluorose dentária entre nós." (ROSSI e OLIVEIRA 1947). Tais argumentos vinham acompanhados de informações sobre o teor de flúor nas águas de Santos (0,2 ppm F), Sorocaba $(0,1$ ppm F), São Roque (0,1 ppm F), Cotia (0,2 ppm F) e Pouso Alegre (menos de 0,1 ppm F).

Quanto à fluorose dentária, já em 1950 Gandra argumentava que, apesar de até então nenhum caso tivesse sido relatado,

"dada a vastidão do território nacional e a variada composição de seu solo, achamos improvável a ausência de casos de fluorose, correndo esta ausência por conta, ao nosso ver, de uma insuficiente difusão dos conhecimentos sôbre o problema, assim como do diminuto número de pesquisas feitas neste sentido." (GANDRA 1950).

Com efeito, apenas em 1970 seria publicado, por Uchôa e Saliba, o primeiro relato sistematizado sobre ocorrência de fluorose dentária endêmica em populações brasileiras, em Pereira Barreto, Estado de São Paulo (UCHÔA e SALIBA 1970).

A cidade de São Paulo conta com uma razoável rede de serviços odontológicos públicos e privados. A proporção dentistas por habitantes está em torno de 10 para 10 mil, excelente se considera-se a meta estabelecida em 1972 pelos ministros de saúde das Américas (2 para 10 mil), a qual deveria ser atingida até 1980 (OPS 1973). Nos serviços públicos, há cirurgiões-dentistas 
desenvolvendo atividades assistenciais em unidades escolares, unidades básicas de saúde, hospitais e prontos-socorros, vinculados a diferentes instituições abrangendo os níveis de governo federal, estadual e municipal (SES-SP 1999).

Pode-se dizer que há na cidade um sistema de prevenção em saúde bucal, com participação tanto de instituições públicas quanto de empresas privadas, cujo eixo central é constituído pela fluoretação das águas de abastecimento público, iniciada oficialmente em 31 de outubro de 1985 (NARVAI e col. 2000).

Em 1991, cerca de $97 \%$ da população residente na cidade tinham acesso à água tratada, clorada e fluoretada (MINISTÉRIO DA SAÚDE 2000).

Segundo NARVAI e col. (2000) o primeiro estudo científico sobre a situação da cárie dentária em escolares da cidade de São Paulo, utilizando o índice CPO-D, foi publicado em 1970, por Souza, que "encontrou o valor de 6,91 para o índice CPO na idade-índice de 12 anos (...) Em 1983 o valor do CPO aos 12 anos de idade foi 7,53 [indicando] para o Município de São Paulo uma prevalência de cárie considerada 'muito alta', segundo a classificação proposta pela OMS." Os autores assinalam que "desde então, verifica-se tendência de declínio na prevalência da cárie entre os escolares, com o CPO atingindo o valor de 2,06 aos 12 anos de idade em 1996" e que no período 1986-1996 houve um "declínio expressivo: 68,2\% aos 12 anos de idade".

NARVAI e col. (2000) assinalam entretanto que, "embora o município apresente um baixo índice CPO-D, a participação do componente dentes cariados, na composição do valor total, reflete 
dificuldade dos serviços assistenciais em assegurar o completo atendimento às necessidades das crianças de 5 a 12 anos de idade. Tais características epidemiológicas traduzem as dificuldades encontradas pelo sistema de saúde para tornar realidade os princípios constitucionais da universalização e eqüidade das ações e serviços de saúde, também na área odontológica."

Ainda segundo estes autores:

"apesar de não haver diferenças estatisticamente significantes [entre escolas públicas e privadas], diferenças relativas aparecem quando se analisa a composição dos valores dos índices: os dentes cariados apresentam percentagens maiores nas escolas públicas comparativamente às escolas privadas. A situação se inverte quando se considera o componente dentes restaurados ("O"). Ambas as populações merecem ter como registro a participação modesta do componente dentes perdidos, evidenciando uma preocupação em não extrair dentes. Essa característica deve ser ressaltada, pois aponta para uma importante mudança de orientação da prática odontológica de sistemática mutilação da população, predominante até os anos 70 , para um enfoque de preservação de órgãos e de estruturas, que começou a se impor a partir dos anos 80 e cujos efeitos já podem ser detectados." (NARVAl e col. 2000).

\subsection{BREVE HISTÓRICO DA FLUORETAÇÃO DA ÁGUA EM SÃO PAULO}


Embora a fluoretação das águas em São Paulo tenha sido autorizada por lei desde 1958 (SÃO PAULO 1958), a medida não foi posta em prática nos anos 60 e 70. Para NARVAI (1980) "o povo costuma dizer que existem leis que pegam e leis que não pegam. Esta, de interesse da maioria da população, não pegou (...) Precisamos todos fazer esta lei pegar."

A redemocratização do Brasil foi decisiva para a fluoretação das águas de abastecimento público no município de São Paulo. Apesar de prometida anteriormente, somente após a realização de eleições diretas para governadores, em 1982, foi possível a tomada de decisão favorável à implantação da medida na região metropolitana de São Paulo, incluindo a capital. Com a eleição de André Franco Montoro criaram-se as condições favoráveis ao cumprimento da lei e à efetivação da medida. Montoro foi eleito com um programa de governo do qual constava expressamente:

"Na saúde oral será dada prioridade à odontologia preventiva, ao invés da curativa, enfatizando-se a: (a) fluoretação das águas de consumo público; (b) aplicação direta de flúor nas regiões onde tal fluoretação inexiste; (c) incentivo ao diagnóstico e tratamento odontológico precoce; (d) atendimento prioritário às crianças, adolescentes e mulheres grávidas; (e) educação sanitária nas escolas (...)”. (MONTORO 1982) [grifos do autor].

Falando em 21/01/1984 na abertura do XI Congresso Paulista de Odontologia, João Yunes, então Secretário de Estado da Saúde, reafirmou o compromisso e anunciou: 
"Este ano, cerca de 45 milhões de cruzeiros serão aplicados no Projeto de Fluoretação da Águas de Abastecimento Público, no interior, enquanto a Sabesp já iniciou a implantação do Projeto de Fluoretação da Água da Grande São Paulo, dando cumprimento à legislação existente desde 1958 e jamais respeitada pelos governos que se sucederam após 64. A conclusão da fluoretação na Grande São Paulo está prevista para os primeiros meses de $86 . "$

Com efeito, segundo Dotta (1985), um dos programas relacionados à qualidade da água desenvolvidos pela Secretaria de Obras e do Meio Ambiente tratava da fluoretação pois "a meta do governo do Estado é ter água fluoretada em todos os municípios paulistas (...) De março/85 a dezembro/85, implantar a fluoretação em 165 municípios com serviços autônomos, e em 134 municípios operados pela Sabesp."

Mas, conforme NARVAI (1996a),

"apesar de consolidada no plano teórico, recomendada pela OMS e por entidades odontológicas nacionais e internacionais, e praticada em vários países e, inclusive, em vários municípios brasileiros, a fluoretação teve ferrenhos opositores. Alguns silenciosos, outros estridentes. Cauteloso quanto aos desdobramentos que a medida poderia ter junto aos cirurgiões-dentistas de São Paulo, o então governador Franco Montoro, acompanhado de autoridades estaduais, inclusive o Secretário de Saúde Dr. João Yunes, esteve na sede da Associação Paulista de Cirurgiões-Dentistas (APCD) para anunciar o início da fluoretação [ver Anexo 1] e, claro, sentir as reações. Felizmente, foi encorajado e 
estimulado a ir em frente, ignorando os opositores. Ficou evidente que eram vozes isoladas, equivocadas ou movidas por interesses menores." Antecipando o cronograma, já no final de outubro de 1985 iniciava-se (Anexo 2) a fluoretação na capital paulista (DAE 1985; CROSP 1985). A medida foi amplamente comunicada à população através dos jornais (Anexos 3 e 4), emissoras de rádio e televisão e incluiu uma carta do engenheiro João Oswaldo Leiva, na ocasião Secretário de Obras e Meio Ambiente, a todos os cirurgiões-dentistas e médicos pediatras em atividade no Estado de São Paulo, inscritos respectivamente no Conselho Regional de Odontologia e Conselho Regional de Medicina (Anexo 5).

Ressalta a importância da decisão tomada em São Paulo o fato de os participantes da I Conferência Nacional de Saúde Bucal (Brasília, 10-12 out. 1986) terem aprovado, no Relatório Final do evento, uma tese denunciando a "não utilização de métodos preventivos de caráter coletivo, de forma sistematizada" e outra mencionando expressamente o "descumprimento da legislação vigente no que se refere à fluoretação das águas." (I CNSB 1986).

Também na II CNSB (Brasília, 25-27 set. 1993) o cumprimento da Lei 6.050/74 foi reivindicado pelos delegados, afirmando-se ser "inadmissível o comportamento adotado pelo poder público quanto à fluoretação das águas de abastecimento público, condenando $70 \%$ da população brasileira a sobreviverem sem esse benefício." (II CNSB 1993).

Mas, segundo NARVAI (1997),

"não foi simples nem fácil tomar a decisão de fluoretar as águas na cidade de São Paulo. A medida encontrou opositores [cujos métodos] 
foram da tentativa de argumentar contra a eficácia e segurança da fluoretação, até estúpidas agressões pessoais e manipulação de notícias (...) Além das manifestações individuais contrárias à fluoretação das águas, pelo menos uma entidade e um movimento tiveram destacada atuação: a UPAFAI - União Paulista Antifluoretação Artificial Inadequada e o Movimento Arte e Pensamento Ecológico. Também a APEDEMA - Assembléia Permanente das Entidades de Defesa do Meio Ambiente de São Paulo, manifestou-se contrária ao início da fluoretação."

A despeito, entretanto, de certa oposição - a qual, em nenhum momento, apresentou qualquer argumento científico consistente contrário à medida -, a fluoretação foi implementada. Em conseqüência, uma década depois, as crianças paulistanas apresentavam, na idade-índice de 12 anos, uma diminuição da ordem de $68 \%$ no valor do índice CPO-D - o qual variou de 6,5 em 1986 para 2,1 em 1996. Aos 12 anos de idade, 39,8\% das crianças estavam livres de cárie (CPO-D=0) (NARVAl e col. 2000).

Ainda que se admita que outros fatores, como a adição de flúor aos dentifrícios e as ações educativas relacionadas à escovação dentária e ao uso de produtos açucarados, tenham tido participação nessa queda, é amplamente reconhecido que, nas condições sócio-econômicas prevalecentes em São Paulo, o principal agente teria sido o flúor presente nas águas.

Para assegurar que a fluoretação das águas fosse realizada em conformidade com as recomendações técnico-científicas, a Secretaria de Estado da Saúde, "considerando que a eficácia preventiva dessa medida 
preventiva da cárie dental está condicionada à continuidade dos programas e ao controle da execução [e que] o acompanhamento e a avaliação dos programas de fluoretação das águas do Estado devem ser objeto de atuação interinstitucional" criou, mediante a Resolução SS-329, de 13/11/1987, um grupo técnico ("Grupo Estadual de Controle da Fluoretação - GECOF”) encarregado de:

"assessoramento da implantação, acompanhamento e avaliação do Programa Estadual de Controle da Fluoretação, com o objetivo de: I assessorar o Secretário e órgãos oficiais em assuntos relativos à fluoretação das águas de abastecimento público; II - acompanhar a implantação e a execução dos programas municipais de fluoretação no Estado de São Paulo; III - avaliar os resultados, a serem apresentados pelos órgãos competentes, produzidos pelas atividades dos programas municipais, acompanhando especialmente: a) o comportamento dos índices ceo-d e CPO-D, utilizados para medir prevalência de cárie dental; e, b) o teor de fluoreto nas águas de abastecimento, medido em diferentes pontos da rede." [grifos do autor] (SÃO PAULO 1987).

Mas, infelizmente, o GECOF não logrou "acompanhar especialmente (...) o teor de fluoreto nas águas de abastecimento, medido em diferentes pontos da rede."

A vigilância sanitária da fluoretação no município de São Paulo, com a medida do teor de fluoreto nas águas de abastecimento, em diferentes pontos da rede, só viria a ser efetivamente desenvolvida a partir de 1990, com a 
criação, pela Secretaria Municipal da Saúde (SMS-SP), do seu sistema de vigilância.

A importância de a população da cidade contar com flúor na água de abastecimento e de esta medida ser controlada pelos órgãos de saúde foi destacada por NARVAI e col. (2000) que assinalaram:

"num contexto sócio-econômico e sanitário bastante adverso, foi possível, num período de cerca de três décadas, conter o avanço da cárie dentária na população escolar de uma metrópole do porte de São Paulo e produzir um expressivo declínio em sua prevalência e severidade. Isso vem sendo possível em razão das ações desenvolvidas por órgãos públicos (fluoretação de águas e programas preventivos, p.ex.) e por empresas privadas (adicionando flúor aos dentifrícios, p.ex.)."

Estes autores destacaram o papel desempenhado pela fluoretação das águas de abastecimento público, "sobretudo porque sua implantação, em 1985, resultou na superação de muitas dificuldades técnico-sanitárias e políticas, tendo sido de extrema complexidade o processo de tomada de decisão em favor dessa medida" e mencionam que, apesar de consolidada no plano teórico, recomendada pela OMS e por entidades odontológicas nacionais e internacionais, e praticada em vários países — inclusive em vários municípios brasileiros -, "a fluoretação teve e continua tendo opositores."

Cabe reiterar, por oportuno, que a OMS, com base nos conhecimentos disponíveis resultantes de centenas de milhares de pesquisas em todo o mundo, tem mantido a recomendação de uso do flúor em saúde pública por 
considerá-lo eficaz na prevenção da cárie dentária e seguro para a saúde humana (WHO 1984, 1994).

\subsection{POLÍTICA DE SAÚDE NO MUNICÍPIO NO PERÍODO 1990-1999}

A Administração Municipal no período 1989-1992, tendo à frente Luiza Erundina de Sousa, implementou uma política de saúde consoante as diretrizes constitucionais (art. 196) que reconheciam a saúde como "direito de todos e dever do Estado, garantido mediante políticas sociais e econômicas que visem à redução do risco de doença e de outros agravos e ao acesso universal e igualitário às ações e serviços para sua promoção, proteção e recuperação" e determinavam (art. 198) que "as ações e serviços públicos de saúde integram uma rede regionalizada e hierarquizada e constituem um sistema único, organizado de acordo com as seguintes diretrizes: I. descentralização, com direção única em cada esfera de governo; II. atendimento integral, com prioridade às atividades preventivas, sem prejuízo dos serviços assistenciais; III. participação da comunidade." (BRASIL 1988).

Para isso, em abril de 1989 a até então denominada Secretaria de Higiene e Saúde (SHS) passou a denominar-se Secretaria Municipal da Saúde (SMS), ao mesmo tempo em que se iniciava uma profunda reestruturação na Pasta com a criação, entre outros órgãos, de 10 (dez) Administrações Regionais de Saúde (ARS). Cada ARS ficou incumbida da gestão dos equipamentos municipais de saúde no território que the correspondia e, gradativamente, o processo de descentralização foi sendo intensificado com a 
criação de unidades administrativas de menor abrangência denominadas Distritos de Saúde (DS) (TELESI JUNIOR 1998).

Segundo COHN e col. (1993) este processo foi conseqüência das propostas de governo "centradas na participação popular, na descentralização, e na democratização dos serviços de saúde, tendo por objetivo a implementação do Sistema Único de Saúde na cidade de São Paulo."

Para NEDER (1998):

"A gestão democrática e popular (...) ampliou significativamente a oferta de serviços na cidade. Foram construídos seis novos hospitais e reformadas ou ampliadas 175 unidades de saúde. A SMS implantou diversos programas inovadores - saúde mental, bucal, DST-AIDS, trabalhador, mulher, criança, deficientes - que revolucionaram as práticas de saúde na cidade. As ações eram integrais, isto é, associavam ações preventivas e de promoção de saúde às atividades de cura e reabilitação. Foram criados mais de 30 mil cargos para os trabalhadores da saúde, o que fez com que a Secretaria realizasse mais de 100 concursos públicos. Essa ação viabilizou uma sensível mudança no quadro de recursos humanos. Em 1989, eram 24 mil servidores, sendo que apenas 30\% eram efetivos. Em 1992, eram 42 mil, dos quais $85 \%$ nomeados por concurso público. O controle público foi exercido através do Conselho Municipal de Saúde. Criado em 1989, respeitava a participação dos usuários e dos movimentos populares de saúde. Foram realizadas três conferências e um encontro municipal de saúde. As ações prioritárias eram definidas nesses fóruns. A 
representação também ocorria nas instâncias locais e regionais, sendo que foram implantados 164 Conselhos Gestores."

Mas a partir de 1995, na gestão de Paulo Salim Maluf (1993-1996), a Prefeitura de São Paulo mudou radicalmente a orientação da política de saúde. O SUS passou a ser visto como inadequado e, rompendo com as determinações legais da Constituição da República (BRASIL 1988) e da Lei Federal 8.080 (BRASIL 1990a), a Prefeitura impôs o Plano de Atendimento à Saúde (PAS) como política pública nesta área (SÁ e col. 1997).

Embora o PAS não tenha sido cogitado durante a campanha eleitoral, não constando portanto do plano de governo apresentado aos eleitores pelo então candidato, nem tenha sido sequer encaminhado à apreciação do Conselho Municipal de Saúde - órgão deliberativo (Lei Federal 8.142, de 28/12/1990) sobre a "formulação de estratégias e no controle da execução da política de saúde" (BRASIL 1990b) —, foi imposto pela Administração Municipal que não hesitou em remover dos quadros da SMS-SP milhares de servidores, transferindo-os para outros órgãos, como a Guarda Civil Metropolitana e secretarias como Obras, Verde e Meio Ambiente, Esportes, e Bem-Estar Social (SÁ e col. 1997), e travar prolongada batalha judicial. Segundo estes autores houve um "êxodo forçado" que:

"resultou em mudanças na estrutura do quadro de pessoal da Secretaria Municipal da Saúde [com] 35.035 remoções/transferências para todos os destinos. (...) As funções típicas de saúde totalizaram 24.505, representando, no geral, $69,94 \%$ daquele total (...)"

Para SÁ e col. (1997): 
"o êxodo significou um retardo na organização política do setor saúde no Município de São Paulo, mantendo por ainda mais tempo, a desarticulação entre os governos municipal e estadual, com anulação do conceito sistêmico inerente à saúde no seu aspecto amplo."

Há depoimentos dramáticos de servidores públicos municipais sobre "a chegada" do PAS a certas unidades de saúde da SMS-SP. Muitos mencionam o período de "sofrimentos", "perseguições" e "humilhações" a que foram submetidos: "fui proibido de voltar ao hospital para pegar meus pertences. Fomos enxotados (...)" (FSP 2000b).

A estratégia adotada pelo Poder Público Municipal com o PAS foi transferir a gestão da saúde no município para a iniciativa privada representada por "cooperativas" de funcionários licenciados da Administração Direta para integrá-las mas, efetivamente, controladas política, financeira e administrativamente por grupos econômicos que não apareciam oficialmente como controladores dessas organizações. As "cooperativas" eram remuneradas por usuários em potencial (número calculado com base na população de uma determinada região a ser atendida), independentemente, portanto, de lhes prestarem ou não serviços de saúde. O princípio constitucional (art. 198) da "participação da comunidade" (BRASIL 1988) exercendo o controle público das ações e serviços de saúde foi, simplesmente, ignorado.

As eleições municipais de 1996 representaram uma transição administrativa marcada essencialmente pela continuidade, no poder municipal, da coligação partidária vitoriosa em 1992. Paulo Salim Maluf foi substituído à 
frente do executivo paulistano por Celso Roberto Pitta do Nascimento, o qual, durante a campanha eleitoral, destacou os aspectos que considerava "qualidades do PAS".

Na gestão Celso Pitta o PAS, conforme defendido durante toda a campanha eleitoral, teve continuidade como expressão da política pública municipal de saúde - embora sofrendo crescente oposição à medida que se acumulavam registros de falhas no atendimento à população e aumentavam as denúncias de casos de corrupção envolvendo dirigentes e funcionários das "cooperativas", da SMS e de empresas fornecedoras da Prefeitura.

Em 2000, após a completa derrocada do PAS enquanto política pública de saúde, mercê de denúncias de desvios de verbas e corrupção em todos os níveis, a Prefeitura criou o SIMS - Sistema Integrado Municipal de Saúde, numa tentativa de se desvencilhar da marca "PAS", a qual se transformara em símbolo de incompetência, descrédito e corrupção. O SIMS não logrou êxito, caracterizando-se por ser, fundamentalmente, a continuidade do PAS com outro nome.

Em abril de 2000, frente às notícias de desaparecimento de aparelhos e equipamentos, Claudete Alves, presidente do Sindicato dos Servidores Públicos Municipais de São Paulo (SINDSEP), propôs a "instalação de uma Comissão Parlamentar de Inquérito para apurar as irregularidades" e reconheceu que, para a implantação do SUS seria "necessário efetuar uma operação de guerra, usando armas democráticas [e] montar vigília nas unidades do PAS para não correr o risco de nada mais encontrar nelas a partir de $1^{\circ}$ de janeiro de 2001." (SINDSEP 2001). 
Em editorial intitulado "Rumo ao Caos", dia 6/12/2000, no crepúsculo da Administração do prefeito Celso Roberto Pitta do Nascimento, o jornal Folha de S.Paulo (FSP 2000) assinalou que:

"mesmo que não houvesse a menor suspeita sobre a lisura das cooperativas, elas no mínimo teriam todo interesse em furtar-se aos atendimentos mais complexos, remetendo o paciente a hospitais da administração direta, notadamente do Estado. E não se pode afirmar que o comportamento das associações que controlam os módulos do PAS seja exemplar. As denúncias de superfaturamento são uma constante. Apesar de trabalhar com verbas da prefeitura, as cooperativas não estão sujeitas a licitações ou outras formas públicas de controle de gastos."

O título do mencionado editorial não baseou-se em possível denúncia de algum político de oposição. O texto esclarecia que o próprio secretário municipal da saúde, Carlos Alberto Velucci, havia definido, no dia anterior (5/12/2000), a situação do sistema de saúde do município como "caminhando para o caos" (FSP 2000b). A propósito da ameaça de paralisação dos serviços de saúde por parte das "cooperativas", sob alegação de falta de pagamentos pela prefeitura, o anestesista João Eduardo Charles - um dos servidores públicos municipais de saúde conhecidos como 'exilados do $P A S$ — teria dito, em entrevista à Folha de S.Paulo, em 10/12/2000, que "não devemos esquecer que na frente das cooperativas existem bandidos e que eles estão raspando $o$ tacho." (FSP 2000a). 
Neste contexto, abrangendo três administrações municipais com políticas de saúde diametralmente opostas, foram desenvolvidas as ações de criação, instalação e desenvolvimento de operações do pioneiro sistema municipal de vigilância sanitária da fluoretação das águas em São Paulo. 


\section{OBJETIVOS}

Constituem objetivos desta pesquisa:

a) descrever o sistema de vigilância sanitária da fluoretação das águas de abastecimento público em operação no município de São Paulo, Brasil, sob responsabilidade da Secretaria Municipal da Saúde; e,

b) analisar os resultados obtidos pelo sistema mencionado no item "a", no período de 1990 a 1999. 


\section{MATERIAL E MÉTODO}

\subsection{O Sistema Municipal de Vigilância da Fluoretação em São Paulo}

Em 31 de outubro de 1985 foi iniciada oficialmente a fluoretação das águas de abastecimento público no município de São Paulo (SÃO PAULO 1985). O teor ótimo de flúor na água é $0,7 \mathrm{mg}$ por litro.

Dados oficiais indicam que, em 1991, 97\% da população tinham acesso à água tratada (MINISTÉRIO DA SAÚDE 2000).

Em 1989 a Secretaria Municipal de Saúde de São Paulo (SMS-SP) resolveu montar um sistema próprio de controle da fluoretação com base no heterocontrole (SÃO PAULO 1989). Assessoria técnica para montagem e desenvolvimento do sistema foi obtida, nos 3 primeiros anos, junto à Faculdade de Saúde Pública (FSP) da Universidade de São Paulo (USP) (Anexo 6). Após a realização de uma pesquisa operacional para verificar a estabilidade do flúor em amostras de água colhidas em diferentes pontos da cidade (PRADO e col. 1992), o sistema foi inaugurado em janeiro de 1990 (SÃO PAULO 1990; SCHNEIDER FILHO e col. 1992).

Foram definidos e fixados 60 (sessenta) pontos de coleta de água, distribuídos por todo o território do município (Anexo 7). A partir de 1993 mais 2 (dois) pontos foram incluídos no sistema - UBS Liberdade (ponto 61) e UBS Parque Anhanguera (ponto 62). Um outro ponto foi incluído em 1997 — PAS Dr. Emilio S. Oliveira (ponto 63). Em 1999 o sistema contava, portanto, com 63 (sessenta e três) pontos de coleta. As razões para essas inclusões não foram informadas nos relatórios. 
São os seguintes os pontos de coleta e respectivas Administrações Regionais de Saúde:

Quadro 1. Locais de coleta de água do sistema municipal de vigilância sanitária da fluoretação das águas, segundo o número do ponto e a Administração Regional de Saúde. São Paulo, SP, 1990-1999.

\begin{tabular}{|c|l|c|}
\hline PONTO & LOCAL DE COLETA & ARS \\
\hline 01 & PAM DR. JOSÉ DE BARROS MAGALDI & 1 \\
\hline 02 & PAM CAMBUCI & 1 \\
\hline 03 & HOSPITAL MUNICIPAL MENINO JESUS & 1 \\
\hline 04 & CLINIICA HUMAITA & 1 \\
\hline 05 & EMPG INFANTE DOM HENRIQUE & 1 \\
\hline 06 & PS BARRA FUNDA & 1 \\
\hline 07 & PAM VILA ROMANA & 2 \\
\hline 08 & EMPG DILERMANDO D. SANTOS & 2 \\
\hline 09 & PAM VILA NOVA JAGUARE & 2 \\
\hline 10 & UBS JARDIM D'ABRIL & 2 \\
\hline 11 & PAM SÃO JORGE & 2 \\
\hline 12 & UBS JARDIM JAQUELINE & 2 \\
\hline 13 & PAM JOAQUIM ROSSINI & 3 \\
\hline 14 & PAM DR. LUIZ ERNESTO MAZZONI & 3 \\
\hline 15 & PAM DR. GERALDO DA SILVA FERREIRA & 3 \\
\hline 16 & PAM TEOTÔNIO VILELA & 3 \\
\hline 17 & UBS JARDIM ELBA & 3 \\
\hline 18 & UBS HERMENEGILDO MORBIN JR. & 3 \\
\hline 19 & UBS VILA GUARANI & 4 \\
\hline 20 & PAM JARDIM SÃO FRANCISCO & 4 \\
\hline 21 & UBS SANTA TEREZINHA & 5 \\
\hline 22 & PAM JARDIM ITAPEMA & 5 \\
\hline 23 & PAM PADRE JOSÉ DE ANCHIETA & 4 \\
\hline 24 & PAM PADRE MANOEL DA NOBREGA & 4 \\
\hline 25 & PAM CASTRO ALVES & 5 \\
\hline 26 & PAM NOSSA SENHORA DO CARMO & 5 \\
\hline 27 & PAM CIDADE LIDER & 5 \\
\hline
\end{tabular}

continua Quadro 1. Locais de coleta de água do sistema municipal de vigilância sanitária da fluoretação das águas, segundo o número do ponto e a Administração Regional de Saúde. São Paulo, 2000. 
continuação

\begin{tabular}{|c|c|c|}
\hline 28 & PAM JOSÉ BONIFÁCIO II & 5 \\
\hline 29 & PAM VILA SANTANA & 5 \\
\hline 30 & PAM JARDIM TIETÉ & 5 \\
\hline 31 & PAM VILA CISPER & 6 \\
\hline 32 & PAM JARDIM HELENA & 6 \\
\hline 33 & PAM PONTE RASA & 4 \\
\hline 34 & PAM JARDIM MAIA & 6 \\
\hline 35 & UBS VILA RAMOS & 5 \\
\hline 36 & UBS VILA JACUI & 6 \\
\hline 37 & PAM PARQUE NOVO MUNDO & 7 \\
\hline 38 & PAM VILA NOVA GALVÃO & 7 \\
\hline 39 & PAM JOAQUIM ANTONIO EIRADO & 7 \\
\hline 40 & PAM JARDIM CAROMBÉ & 7 \\
\hline 41 & PAM FREGUESIA DO Ó & 7 \\
\hline 42 & PAM DONA MARIQUINHA SCIACIA & 7 \\
\hline 43 & PS PERUS & 8 \\
\hline 44 & PAM ELISIO TEIXEIRA LEITE & 8 \\
\hline 45 & UBS JARDIM IPANEMA & 8 \\
\hline 46 & PAM VILA JAGUARA & 2 \\
\hline 47 & PAM MOINHO VELHO & 8 \\
\hline 48 & PAM JARDIM CIDADE PIRITUBA & 8 \\
\hline 49 & UBS PARELHEIROS & 9 \\
\hline 50 & PAM CHÁCARA SANTO ANTONIO & 9 \\
\hline 51 & PAM VILA GUACURI & 9 \\
\hline 52 & PAM VELEIROS & 9 \\
\hline 53 & PAM JARDIM ELIANA & 9 \\
\hline 54 & PAM JARDIM MIRNA & 9 \\
\hline 55 & UBS JARDIM SÃO BENTO & 10 \\
\hline 56 & UBS JARDIM MARCELO & 10 \\
\hline 57 & PAM CAMPO LIMPO & 10 \\
\hline 58 & UBS JARDIM ANGELA & 10 \\
\hline 59 & PAM JARDIM TOMÁS & 10 \\
\hline 60 & PAM JARDIM HERCULANO & 10 \\
\hline 61 & UBS PARQUE ANHANGUERA & 8 \\
\hline 62 & UBS DR. CARLOS MUNIZ & 4 \\
\hline 63 & UBS DR. EMILIO S. OLIVEIRA & 4 \\
\hline
\end{tabular}

Nesses pontos as amostras são colhidas diretamente de torneiras, nas condições em que a água é consumida. Tais pontos de coleta abrangem toda a rede municipal de abastecimento, cuja água provém, segundo a SABESP, de 7 (sete) sistemas de abastecimento: Alto Cotia, Alto Tietê, Baixo Cotia, 
Cantareira, Guarapiranga, Rio Claro e Rio Grande (as capacidades de produção de cada um desses sistemas, medidas em litros d'água por segundo são, respectivamente: 1.300; 10.000; 900; 33.000; 13.000; 3.800; 4.200). (Anexo 8).

As amostras de água são colhidas uma vez por mês, em dia definido ao acaso, adotando-se o critério de fixação de locais, de modo a obter-se, sistematicamente, informações relativas ao mesmo local construindo-se séries históricas que permitam análises temporais.

Armazenada em frasco plástico, cada amostra é devidamente identificada (local, dia, coletor) (Anexo 9) e segue um determinado fluxo até ser analisada no Laboratório de Controle de Alimentos da Secretaria Municipal de Abastecimento. Após as análises químicas os resultados são enviados ao nível central da SMS-SP onde os dados são analisados e é elaborado o relatório. O nível central da SMS divulga o relatório e adota as providências cabíveis (Anexo 10).

A conferência dos resultados obtidos pelo sistema ("checagem”) foi feita, nos 3 primeiros anos, através de reexame de parte das amostras (10\%) pelo próprio examinador (erro intra-examinador) e pelo Laboratório de Bioquímica da Faculdade de Odontologia de Piracicaba, da Universidade Estadual de Campinas (erro interexaminadores).

\subsection{Classificação das Amostras e dos Locais}

As amostras de água foram classificadas segundo o teor de flúor observado em cada mês. A análise da condição de cada local, no período de 
um ano, foi feita com base nos teores de flúor desse conjunto de amostras mensais.

O teor de flúor na amostra é utilizado para classificá-las como "aceitáveis" ou "inaceitáveis", conforme a quantidade de flúor encontrada. Quando essa quantidade situa-se na faixa de 0,6 a $0,8 \mathrm{mgF} / \mathrm{l}$ (ou ppm) a amostra é considerada "aceitável". É "inaceitável" quando o teor está fora dessa faixa, conforme o Quadro 2.

QuADRo 2. Classificação das amostras de água segundo o teor de flúor.

Município de São Paulo, SP, 1990-1999.

\begin{tabular}{|lr|}
\hline TEOR DE FLÚOR & CONCENTRAÇÃO \\
\hline Até $0,59 \mathrm{ppm}$ & inaceitável \\
\hline $0,60 \mathrm{ppm}$ & mínima aceitável \\
\hline $0,61 \mathrm{a} 0,69 \mathrm{ppm}$ & sub-ótima \\
\hline $0,70 \mathrm{ppm}$ & ótima \\
\hline $0,71 \mathrm{a} 0,79 \mathrm{ppm}$ & supra-ótima \\
\hline $0,80 \mathrm{ppm}$ & máxima aceitável \\
\hline $0,81 \mathrm{a} 1,19 \mathrm{ppm}$ & inadequada \\
\hline $1,20 \mathrm{ppm}$ & limite \\
\hline $1,21 \mathrm{ppm}$ ou mais & inaceitável \\
\hline
\end{tabular}

Fonte: SÃO PAULO (Município), 1990.

A condição do local em termos da disponibilidade de flúor na água é avaliada segundo a quantidade de amostras "aceitáveis" durante o ano. A condição do local é "adequada" quando pelo menos 10 das 12 amostras anuais são "aceitáveis". Para essa análise de adequação é imprescindível que se disponha de pelo menos 9 das 12 amostras possíveis. Assim, admite-se a 
possibilidade de até 90 dias sem informação por ano para a caracterização de um determinado local quanto à sua adequação.

\subsection{Dados}

Os dados são os registros mensais do teor de flúor na água nos 63 pontos de coleta. Os valores das amostras são reunidos em relatório publicado pela SMS-SP no Diário Oficial do Município de São Paulo (DOM). Esses relatórios anuais, referentes ao período 1990-1999, constituíram a base de dados consultada para empreender a análise apresentada neste estudo. 


\section{RESULTADOS}

\subsection{Teor de Flúor na Amostra}

Os teores de flúor encontrados nas amostras, considerando o município como um todo, estão apresentados nas tabelas de número 3 a 12, para cada ano do período 1990-1999.

Tabela 3. Classificação das amostras de águas de abastecimento público segundo o teor de flúor. São Paulo, SP, Brasil, 1990.

\begin{tabular}{ccc}
\hline TEOR DE FLÚOR & $\mathrm{N}$ & $\%$ \\
\hline Aceitável & 578 & 83,3 \\
Inaceitável & 116 & 16,7 \\
\hline TOTAL & 694 & 100,0 \\
\hline
\end{tabular}

Fonte: SÃO PAULO (Município). Secretaria Municipal da Saúde (1991).

Tabela 4. Classificação das amostras de águas de abastecimento público segundo o teor de flúor. São Paulo, SP, Brasil, 1991.

\begin{tabular}{ccc}
\hline TEOR DE FLÚOR & $\mathrm{N}$ & $\%$ \\
\hline Aceitável & 488 & 80,0 \\
Inaceitável & 122 & 20,0 \\
\hline TOTAL & 610 & 100,0 \\
\hline
\end{tabular}

Fonte: SÃO PAULO (Município). Secretaria Municipal da Saúde (1992). 
Tabela 5. Classificação das amostras de águas de abastecimento público segundo o teor de flúor. São Paulo, SP, Brasil, 1992.

\begin{tabular}{ccc}
\hline TEOR DE FLÚOR & $\mathrm{N}$ & $\%$ \\
\hline Aceitável & 512 & 79,8 \\
Inaceitável & 130 & 20,2 \\
\hline TOTAL & 642 & 100,0 \\
\hline
\end{tabular}

Fonte: SÃO PAULO (Município). Secretaria Municipal da Saúde (1993).

Tabela 6. Classificação das amostras de águas de abastecimento público segundo o teor de flúor. São Paulo, SP, Brasil, 1993.

\begin{tabular}{ccc}
\hline TEOR DE FLÚOR $\left(^{*}\right)$ & $\mathrm{N}$ & $\%$ \\
\hline Aceitável & 532 & 97,8 \\
Inaceitável & 12 & 2,2 \\
\hline TOTAL & 544 & 100,0 \\
\hline
\end{tabular}

(*) A SMS não informou os dados relativos a novembro e dezembro.

Fonte: SÃO PAULO (Município). Secretaria Municipal da Saúde (1994). 
Tabela 7. Classificação das amostras de águas de abastecimento público segundo o teor de flúor. São Paulo, SP, Brasil, 1994.

\begin{tabular}{ccc}
\hline TEOR DE FLÚOR & $\mathrm{N}$ & $\%$ \\
\hline Aceitável & 607 & 97,1 \\
Inaceitável & 18 & 2,9 \\
\hline TOTAL & 625 & 100,0 \\
\hline
\end{tabular}

Fonte: SÃO PAULO (Município). Secretaria Municipal da Saúde (1995).

Tabela 8. Classificação das amostras de águas de abastecimento público segundo o teor de flúor. São Paulo, SP, Brasil, 1995.

\begin{tabular}{ccc}
\hline TEOR DE FLÚOR & $\mathrm{N}$ & $\%$ \\
\hline Aceitável & 575 & 98,6 \\
Inaceitável & 8 & 1,4 \\
\hline TOTAL & 583 & 100,0 \\
\hline
\end{tabular}

Fonte: SÃO PAULO (Município). Secretaria Municipal da Saúde (1996). 
Tabela 9. Classificação das amostras de águas de abastecimento público segundo o teor de flúor. São Paulo, SP, Brasil, 1996.

\begin{tabular}{ccc}
\hline TEOR DE FLÚOR & $\mathrm{N}$ & $\%$ \\
\hline Aceitável & 566 & 98,3 \\
Inaceitável & 10 & 1,7 \\
\hline TOTAL & 576 & 100,0 \\
\hline
\end{tabular}

Fonte: SÃO PAULO (Município). Secretaria Municipal da Saúde (1997).

Tabela 10. Classificação das amostras de águas de abastecimento público segundo o teor de flúor. São Paulo, SP, Brasil, 1997.

\begin{tabular}{ccc}
\hline TEOR DE FLÚOR & $\mathrm{N}$ & $\%$ \\
\hline Aceitável & 717 & 99,8 \\
Inaceitável & 1 & 0,2 \\
\hline TOTAL & 718 & 100,0 \\
\hline
\end{tabular}

Fonte: SÃO PAULO (Município). Secretaria Municipal da Saúde (1998). 
Tabela 11. Classificação das amostras de águas de abastecimento público segundo o teor de flúor. São Paulo, SP, Brasil, 1998.

\begin{tabular}{ccc}
\hline TEOR DE FLÚOR & N & $\%$ \\
\hline Aceitável & 727 & 100,0 \\
Inaceitável & - & - \\
Sem Informação & - & - \\
\hline TOTAL & 727 & 100,0 \\
\hline
\end{tabular}

Fonte: SÃO PAULO (Município). Secretaria Municipal da Saúde (1999).

Tabela 12. Classificação das amostras de águas de abastecimento público segundo o teor de flúor. São Paulo, SP, Brasil, 1999.

\begin{tabular}{ccc}
\hline TEOR DE FLÚOR & $\mathrm{N}$ & $\%$ \\
\hline Aceitável & 728 & 100,0 \\
Inaceitável & - & - \\
\hline TOTAL & 728 & 100,0 \\
\hline
\end{tabular}

Fonte: SÃO PAULO (Município). Secretaria Municipal da Saúde (2000). 
No primeiro ano de funcionamento do sistema (1990) foram obtidas 694 das 720 amostras possíveis (Tabela 3). Dessas 578 (83,3\%) foram consideradas aceitáveis e 116 (16,7\%) inaceitáveis.

Figura 1

CONDIÇÕES DAS AMOSTRAS QUANTO À FLUORETAÇÃO. SÃO PAULO, 1990-1999.

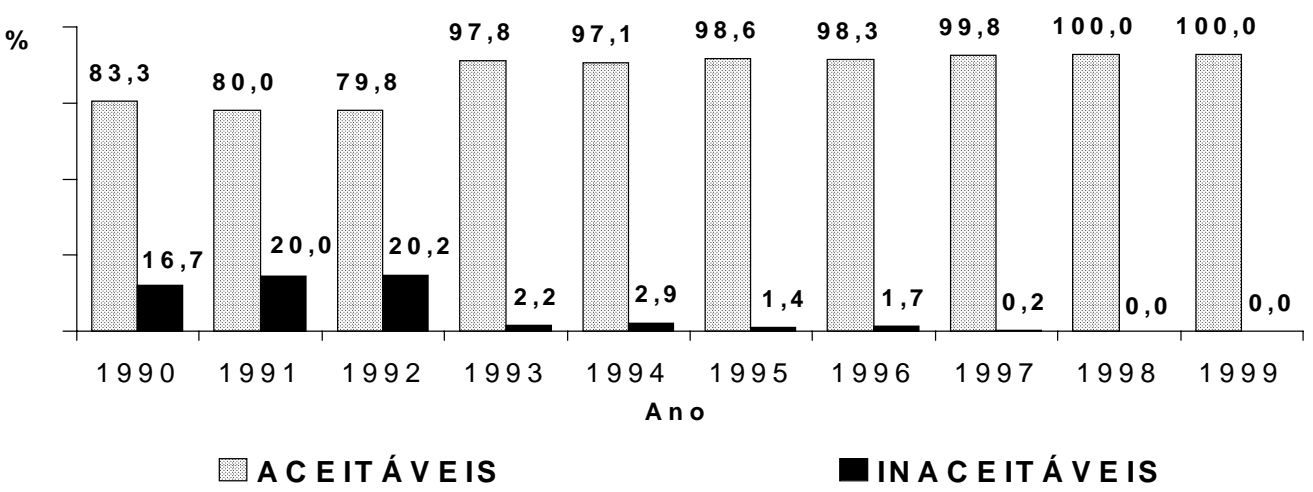

No segundo ano (1991), constatou-se que apenas $488(80,0 \%)$ das amostras foram aceitáveis (Tabela 4).

Tal porcentagem praticamente manteve-se no terceiro ano (1992), com $79,8 \%$ das amostras aceitáveis (Tabela 5).

A SMS não informou os dados relativos aos meses de novembro e dezembro de 1993 no relatório referente ao segundo semestre daquele ano, publicado no Diário Oficial do Município em 8/01/1994. Não foi possível identificar alguma publicação posterior, relativa a estes dois meses. Assim, considerou-se neste estudo que tais informações não foram obtidas ou 
perderam-se ou, ainda, não puderam ser localizadas (solicitação de dados feita à SMS ficou sem resposta até o final de dezembro de 2000 , quando a pesquisa foi encerrada).

A partir de 1994 a situação melhorou gradativamente, atingindo um patamar superior a $96 \%$ nos anos seguintes, até atingir $100 \%$ de amostras aceitáveis em 1998 e 1999.

A Figura 1 mostra a série histórica correspondente ao período 19901999.

Considerando o período 1990-1999 e também o número de pontos (inclusive os 2 pontos incluídos a partir de 1993 e o ponto incluído a partir de 1997) teria sido possível coletar 7.404 amostras de água. Na Tabela 13 apresenta-se a distribuição da freqüência com que ocorreram diferentes teores de flúor nessas amostras, inclusive os teores considerados aberrantes. Constata-se que em 6.013 amostras os teores de flúor variaram entre 0,6 e 0,8 ppm. Isto corresponde a $81,21 \%$ das amostras possíveis e a $93,38 \%$ das amostras efetivamente colhidas. 
Tabela 13. Teores de flúor (em ppm) identificados em amostras de água de abastecimento público. São Paulo, SP, Brasil, 1990-1999.

\begin{tabular}{|c|c|c|}
\hline TEOR DE FLÚOR (ppm) & $\mathrm{N}$ & $\%$ \\
\hline 0,1 & 89 & 1,20 \\
\hline 0,2 & 50 & 0,67 \\
\hline 0,3 & 25 & 0,34 \\
\hline 0,4 & 49 & 0,66 \\
\hline 0,5 & 190 & 2,57 \\
\hline 0,6 & 2.109 & 28,48 \\
\hline 0,7 & 3.705 & 50,04 \\
\hline 0,8 & 199 & 2,69 \\
\hline 0,9 & 3 & 0,04 \\
\hline 1,0 & 3 & 0,04 \\
\hline 1,1 & 2 & 0,03 \\
\hline 1,2 & 1 & 0,01 \\
\hline 1,3 & 1 & 0,01 \\
\hline 1,7 & 1 & 0,01 \\
\hline 1,8 & 1 & 0,01 \\
\hline 1,9 & 1 & 0,01 \\
\hline 2,4 & 1 & 0,01 \\
\hline 2,5 & 1 & 0,01 \\
\hline 2,6 & 1 & 0,01 \\
\hline 3,0 & 2 & 0,03 \\
\hline 3,5 & 1 & 0,01 \\
\hline 4,1 & 1 & 0,01 \\
\hline 7,5 & 1 & 0,01 \\
\hline 13,0 & 1 & 0,01 \\
\hline 15,0 & 1 & 0,01 \\
\hline Sem Informação & 965 & 13,03 \\
\hline TOTAL & 7.404 & 100,00 \\
\hline
\end{tabular}

Fonte: SÃO PAULO (Município). Relatórios técnicos da Secretaria da Saúde. 
Os teores de flúor encontrados nas amostras, segundo o ano, no período 1990-1999, considerando o município como um todo, estão apresentados nas tabelas de número 14 a 23.

Tabela 14. Teores de flúor (em ppm) identificados em amostras de água de abastecimento público. São Paulo, SP, Brasil, 1990.

\begin{tabular}{ccc}
\hline TEOR DE FLÚOR $(\mathrm{ppm})$ & $\mathrm{N}$ & $\%$ \\
\hline 0,1 & 19 & 2,64 \\
0,2 & 14 & 1,94 \\
0,3 & 3 & 0,42 \\
0,4 & 7 & 0,97 \\
0,5 & 73 & 10,14 \\
0,6 & 484 & 67,22 \\
0,7 & 89 & 12,36 \\
0,8 & 3 & 0,42 \\
0,9 & 1 & 0,14 \\
1,0 & 1 & 0,14 \\
Sem Informação & 26 & 3,61 \\
\hline TOTAL & 720 & 100,00 \\
\hline
\end{tabular}

Fonte: SÃO PAULO (1991). 
Tabela 15. Teores de flúor (em ppm) identificados em amostras de água de abastecimento público. São Paulo, SP, Brasil, 1991.

\begin{tabular}{ccc}
\hline TEOR DE FLÚOR $(\mathrm{ppm})$ & $\mathrm{N}$ & $\%$ \\
\hline 0,1 & 28 & 3,89 \\
0,2 & 7 & 0,97 \\
0,3 & 6 & 0,83 \\
0,4 & 16 & 2,22 \\
0,5 & 62 & 8,61 \\
0,6 & 225 & 31,25 \\
0,7 & 190 & 26,39 \\
0,8 & 73 & 10,14 \\
0,9 & 2 & 0,28 \\
Sem Informação & 111 & 15,42 \\
\hline TOTAL & 720 & 100,00 \\
\hline
\end{tabular}

Fonte: SÃO PAULO (1992). 
Tabela 16. Teores de flúor (em ppm) identificados em amostras de água de abastecimento público. São Paulo, SP, Brasil, 1992.

\begin{tabular}{ccc}
\hline TEOR DE FLÚOR $(\mathrm{ppm})$ & $\mathrm{N}$ & $\%$ \\
\hline 0,1 & 42 & 5,83 \\
0,2 & 20 & 2,78 \\
0,3 & 12 & 1,67 \\
0,4 & 20 & 2,78 \\
0,5 & 35 & 4,86 \\
0,6 & 151 & 20,97 \\
0,7 & 330 & 45,83 \\
0,8 & 31 & 4,30 \\
1,1 & 1 & 0,14 \\
1,9 & 1 & 0,14 \\
Sem Informação & 77 & 10,70 \\
\hline TOTAL & 720 & 100,00 \\
\hline
\end{tabular}

Fonte: SÃO PAULO (1993). 
Tabela 17. Teores de flúor (em ppm) identificados em amostras de água de abastecimento público. São Paulo, SP, Brasil, 1993.

\begin{tabular}{ccc}
\hline TEOR DE FLÚOR $(\mathrm{ppm})$ & $\mathrm{N}$ & $\%$ \\
\hline 0,2 & 9 & 1,21 \\
0,3 & 1 & 0,13 \\
0,5 & 1 & 0,13 \\
0,6 & 184 & 24,73 \\
0,7 & 339 & 45,57 \\
0,8 & 7 & 0,94 \\
1,3 & 1 & 0,13 \\
Sem Informação & 202 & 27,16 \\
\hline TOTAL & 744 & 100,00 \\
\hline
\end{tabular}

Fonte: SÃO PAULO (1994).

Tabela 18. Teores de flúor (em ppm) identificados em amostras de água de abastecimento público. São Paulo, SP, Brasil, 1994.

\begin{tabular}{ccc}
\hline TEOR DE FLÚOR $(\mathrm{ppm})$ & $\mathrm{N}$ & $\%$ \\
\hline 0,3 & 3 & 0,40 \\
0,4 & 4 & 0,54 \\
0,5 & 16 & 2,15 \\
0,6 & 298 & 40,05 \\
0,7 & 295 & 39,65 \\
0,8 & 8 & 1,08 \\
0,9 & 1 & 0,13 \\
Sem Informação & 119 & 16,00 \\
\hline TOTAL & 744 & 100,00 \\
\hline
\end{tabular}

Fonte: SÃO PAULO (1995). 
Tabela 19. Teores de flúor (em ppm) identificados em amostras de água de abastecimento público. São Paulo, SP, Brasil, 1995.

\begin{tabular}{ccc}
\hline TEOR DE FLÚOR $(\mathrm{ppm})$ & $\mathrm{N}$ & $\%$ \\
\hline 0,4 & 2 & 0,27 \\
0,5 & 2 & 0,27 \\
0,6 & 127 & 17,08 \\
0,7 & 405 & 54,44 \\
0,8 & 42 & 5,65 \\
2,5 & 1 & 0,13 \\
3,0 & 1 & 0,13 \\
3,5 & 1 & 0,13 \\
7,5 & 1 & 0,13 \\
Sem Informação & 162 & 21,77 \\
\hline TOTAL & 744 & 100,00 \\
\hline
\end{tabular}

Fonte: SÃO PAULO (1996). 
Tabela 20. Teores de flúor (em ppm) identificados em amostras de água de abastecimento público. São Paulo, SP, Brasil, 1996.

\begin{tabular}{ccc}
\hline TEOR DE FLÚOR $(\mathrm{ppm})$ & $\mathrm{N}$ & $\%$ \\
\hline 0,5 & 1 & 0,13 \\
0,6 & 97 & 13,05 \\
0,7 & 433 & 58,21 \\
0,8 & 30 & 4,03 \\
1,0 & 2 & 0,27 \\
1,1 & 1 & 0,13 \\
1,2 & 1 & 0,13 \\
1,8 & 1 & 0,13 \\
2,6 & 1 & 0,13 \\
3,0 & 1 & 0,13 \\
4,1 & 1 & 0,13 \\
13,0 & 1 & 0,13 \\
Sem Informação & 174 & 23,40 \\
\hline TOTAL & 744 & 100,00 \\
\hline
\end{tabular}

Fonte: SÃO PAULO (1997). 
Tabela 21. Teores de flúor (em ppm) identificados em amostras de água de abastecimento público. São Paulo, SP, Brasil, 1997.

\begin{tabular}{ccc}
\hline TEOR DE FLÚOR $(\mathrm{ppm})$ & $\mathrm{N}$ & $\%$ \\
\hline 0,6 & 193 & 25,53 \\
0,7 & 522 & 69,05 \\
0,8 & 2 & 0,26 \\
2,4 & 1 & 0,13 \\
Sem Informação & 38 & 5,03 \\
\hline TOTAL & 756 & 100,00 \\
\hline
\end{tabular}

Fonte: SÃO PAULO (1998).

Tabela 22. Teores de flúor (em ppm) identificados em amostras de água de abastecimento público. São Paulo, SP, Brasil, 1998.

\begin{tabular}{ccc}
\hline TEOR DE FLÚOR $(\mathrm{ppm})$ & $\mathrm{N}$ & $\%$ \\
\hline 0,6 & 105 & 13,89 \\
0,7 & 621 & 82,14 \\
0,8 & 1 & 0,13 \\
Sem Informação & 29 & 3,84 \\
\hline TOTAL & 756 & 100,00 \\
\hline
\end{tabular}

Fonte: SÃO PAULO (1999). 
Tabela 23. Teores de flúor (em ppm) identificados em amostras de água de abastecimento público. São Paulo, SP, Brasil, 1999.

\begin{tabular}{ccc}
\hline TEOR DE FLÚOR $(\mathrm{ppm})$ & $\mathrm{N}$ & $\%$ \\
\hline 0,6 & 251 & 33,20 \\
0,7 & 475 & 62,84 \\
0,8 & 2 & 0,26 \\
Sem Informação & 28 & 3,70 \\
\hline TOTAL & 756 & 100,00 \\
\hline
\end{tabular}

Fonte: SÃO PAULO (2000).

Os teores de flúor encontrados nas amostras, segundo o mês, no período 1990-1999, considerando o município como um todo, estão apresentados nas tabelas de número 24 a 35. 
Tabela 24. Teores de flúor (em ppm) identificados em amostras de água de abastecimento público nos meses de janeiro. São Paulo, SP, Brasil, 19901999.

\begin{tabular}{ccc}
\hline TEOR DE FLÚOR $(\mathrm{ppm})$ & $\mathrm{N}$ & $\%$ \\
\hline 0,2 & 1 & 0,16 \\
0,3 & 1 & 0,16 \\
0,4 & 2 & 0,32 \\
0,5 & 24 & 3,89 \\
0,6 & 162 & 26,27 \\
0,7 & 352 & 57,06 \\
0,8 & 11 & 1,78 \\
0,9 & 1 & 0,16 \\
1,1 & 1 & 0,16 \\
2,6 & 1 & 0,16 \\
4,1 & 1 & 0,16 \\
Sem Informação & 60 & 9,72 \\
\hline TOTAL & 617 & 100,00 \\
\hline
\end{tabular}

Fonte: SÃO PAULO (Município). Relatórios técnicos da Secretaria da Saúde. 
Tabela 25. Teores de flúor (em ppm) identificados em amostras de água de abastecimento público nos meses de fevereiro. São Paulo, SP, Brasil, 19901999.

\begin{tabular}{ccc}
\hline TEOR DE FLÚOR $(\mathrm{ppm})$ & $\mathrm{N}$ & $\%$ \\
\hline 0,2 & 1 & 0,16 \\
0,3 & 1 & 0,16 \\
0,4 & 1 & 0,16 \\
0,5 & 22 & 3,57 \\
0,6 & 197 & 31,93 \\
0,7 & 315 & 51,06 \\
0,8 & 18 & 2,92 \\
1,8 & 1 & 0,16 \\
1,9 & 1 & 0,16 \\
3,0 & 1 & 0,16 \\
Sem Informação & 59 & 9,56 \\
\hline TOTAL & 617 & 100,00 \\
\hline
\end{tabular}

Fonte: SÃO PAULO (Município). Relatórios técnicos da Secretaria da Saúde. 
Tabela 26. Teores de flúor (em ppm) identificados em amostras de água de abastecimento público nos meses de março. São Paulo, SP, Brasil, 1990-1999.

\begin{tabular}{ccc}
\hline TEOR DE FLÚOR $(\mathrm{ppm})$ & $\mathrm{N}$ & $\%$ \\
\hline 0,1 & 13 & 2,11 \\
0,2 & 15 & 2,43 \\
0,3 & 14 & 2,27 \\
0,4 & 22 & 3,57 \\
0,5 & 29 & 4,70 \\
0,6 & 156 & 25,29 \\
0,7 & 295 & 47,81 \\
0,8 & 15 & 2,43 \\
1,0 & 1 & 0,16 \\
1,1 & 1 & 0,16 \\
1,7 & 1 & 0,16 \\
1,3 & 1 & 0,01 \\
1,7 & 1 & 0,01 \\
Sem Informação & 55 & 8,91 \\
\hline TOTAL & 617 & 100,00 \\
\hline
\end{tabular}

Fonte: SÃO PAULO (Município). Relatórios técnicos da Secretaria da Saúde. 
Tabela 27. Teores de flúor (em ppm) identificados em amostras de água de abastecimento público nos meses de abril. São Paulo, SP, Brasil, 1990-1999.

\begin{tabular}{ccc}
\hline TEOR DE FLÚOR $(\mathrm{ppm})$ & $\mathrm{N}$ & $\%$ \\
\hline 0,1 & 38 & 6,16 \\
0,2 & 12 & 1,94 \\
0,3 & 3 & 0,49 \\
0,4 & 4 & 0,65 \\
0,5 & 11 & 1,78 \\
0,6 & 166 & 26,90 \\
0,7 & 311 & 50,41 \\
0,8 & 4 & 0,65 \\
13,0 & 1 & 0,16 \\
Sem Informação & 67 & 10,86 \\
\hline TOTAL & 617 & 100,00 \\
\hline
\end{tabular}

Fonte: SÃO PAULO (Município). Relatórios técnicos da Secretaria da Saúde.

Tabela 28. Teores de flúor (em ppm) identificados em amostras de água de abastecimento público nos meses de maio. São Paulo, SP, Brasil, 1990-1999.

\begin{tabular}{ccc}
\hline TEOR DE FLÚOR $(\mathrm{ppm})$ & $\mathrm{N}$ & $\%$ \\
\hline 0,1 & 24 & 3,89 \\
0,2 & 15 & 2,43 \\
0,3 & 3 & 0,49 \\
0,4 & 7 & 1,13 \\
0,5 & 6 & 0,97 \\
0,6 & 128 & 20,75 \\
0,7 & 284 & 46,03 \\
0,8 & 11 & 1,78 \\
Sem Informação & 139 & 22,53 \\
\hline TOTAL & 617 & 100,00 \\
\hline
\end{tabular}

Fonte: SÃO PAULO (Município). Relatórios técnicos da Secretaria da Saúde. 
Tabela 29. Teores de flúor (em ppm) identificados em amostras de água de abastecimento público nos meses de junho. São Paulo, SP, Brasil, 1990-1999.

\begin{tabular}{ccc}
\hline TEOR DE FLÚOR $(\mathrm{ppm})$ & $\mathrm{N}$ & $\%$ \\
\hline 0,1 & 4 & 0,65 \\
0,2 & 2 & 0,32 \\
0,3 & 1 & 0,16 \\
0,4 & 4 & 0,65 \\
0,5 & 22 & 3,57 \\
0,6 & 206 & 33,39 \\
0,7 & 274 & 44,40 \\
0,8 & 18 & 2,92 \\
3,5 & 1 & 0,16 \\
Sem Informação & 85 & 13,78 \\
\hline TOTAL & 617 & 100,00 \\
\hline
\end{tabular}

Fonte: SÃO PAULO (Município). Relatórios técnicos da Secretaria da Saúde. 
Tabela 30. Teores de flúor (em ppm) identificados em amostras de água de abastecimento público nos meses de julho. São Paulo, SP, Brasil, 1990-1999.

\begin{tabular}{ccc}
\hline TEOR DE FLÚOR $(\mathrm{ppm})$ & $\mathrm{N}$ & $\%$ \\
\hline 0,1 & 4 & 0,65 \\
0,2 & 1 & 0,16 \\
0,3 & 1 & 0,16 \\
0,4 & 4 & 0,65 \\
0,5 & 35 & 5,67 \\
0,6 & 221 & 35,82 \\
0,7 & 272 & 44,08 \\
0,8 & 16 & 2,60 \\
1,0 & 1 & 0,16 \\
Sem Informação & 62 & 10,05 \\
\hline TOTAL & 617 & 100,00 \\
\hline
\end{tabular}

Fonte: SÃO PAULO (Município). Relatórios técnicos da Secretaria da Saúde. 
Tabela 31. Teores de flúor (em ppm) identificados em amostras de água de abastecimento público nos meses de agosto. São Paulo, SP, Brasil, 19901999.

\begin{tabular}{ccc}
\hline TEOR DE FLÚOR $(\mathrm{ppm})$ & $\mathrm{N}$ & $\%$ \\
\hline 0,1 & 6 & 0,98 \\
0,2 & 1 & 0,16 \\
0,3 & 1 & 0,16 \\
0,4 & 2 & 0,32 \\
0,5 & 7 & 1,13 \\
0,6 & 179 & 29,01 \\
0,7 & 291 & 47,16 \\
0,8 & 37 & 6,00 \\
0,9 & 1 & 0,16 \\
2,4 & 1 & 0,16 \\
Sem Informação & 91 & 14,76 \\
\hline TOTAL & 617 & 100,00 \\
\hline
\end{tabular}

Fonte: SÃO PAULO (Município). Relatórios técnicos da Secretaria da Saúde. 
Tabela 32. Teores de flúor (em ppm) identificados em amostras de água de abastecimento público nos meses de setembro. São Paulo, SP, Brasil, 19901999.

\begin{tabular}{ccc}
\hline TEOR DE FLÚOR $(\mathrm{ppm})$ & $\mathrm{N}$ & $\%$ \\
\hline 0,2 & 1 & 0,16 \\
0,4 & 1 & 0,16 \\
0,5 & 5 & 0,81 \\
0,6 & 176 & 28,53 \\
0,7 & 371 & 60,13 \\
0,8 & 10 & 1,62 \\
Sem Informação & 53 & 8,59 \\
\hline TOTAL & 617 & 100,00 \\
\hline
\end{tabular}

Fonte: SÃO PAULO (Município). Relatórios técnicos da Secretaria da Saúde.

Tabela 33. Teores de flúor (em ppm) identificados em amostras de água de abastecimento público nos meses de outubro. São Paulo, SP, Brasil, 19901999.

\begin{tabular}{ccc}
\hline TEOR DE FLÚOR $(\mathrm{ppm})$ & $\mathrm{N}$ & $\%$ \\
\hline 0,2 & 1 & 0,16 \\
0,5 & 3 & 0,49 \\
0,6 & 203 & 32,90 \\
0,7 & 333 & 53,97 \\
0,8 & 16 & 2,60 \\
1,2 & 1 & 0,16 \\
1,3 & 1 & 0,16 \\
3,0 & 1 & 0,16 \\
15,0 & 1 & 0,16 \\
Sem Informação & 57 & 9,24 \\
\hline TOTAL & 617 & 100,00 \\
\hline
\end{tabular}

Fonte: SÃO PAULO (Município). Relatórios técnicos da Secretaria da Saúde. 
Tabela 34. Teores de flúor (em ppm) identificados em amostras de água de abastecimento público nos meses de novembro. São Paulo, SP, Brasil, 19901999.

\begin{tabular}{ccc}
\hline TEOR DE FLÚOR $(\mathrm{ppm})$ & $\mathrm{N}$ & $\%$ \\
\hline 0,5 & 21 & 3,40 \\
0,6 & 148 & 23,99 \\
0,7 & 296 & 47,98 \\
0,8 & 34 & 5,51 \\
0,9 & 1 & 0,16 \\
Sem Informação & 117 & 18,96 \\
\hline TOTAL & 617 & 100,00 \\
\hline
\end{tabular}

Fonte: SÃO PAULO (Município). Relatórios técnicos da Secretaria da Saúde.

Tabela 35. Teores de flúor (em ppm) identificados em amostras de água de abastecimento público nos meses de dezembro. São Paulo, SP, Brasil, 19901999.

\begin{tabular}{ccc}
\hline TEOR DE FLÚOR $(\mathrm{ppm})$ & $\mathrm{N}$ & $\%$ \\
\hline 0,4 & 2 & 0,32 \\
0,5 & 5 & 0,81 \\
0,6 & 173 & 28,04 \\
0,7 & 305 & 49,43 \\
0,8 & 9 & 1,47 \\
1,0 & 1 & 0,16 \\
2,5 & 1 & 0,16 \\
7,5 & 1 & 0,16 \\
Sem Informação & 120 & 19,45 \\
\hline TOTAL & 617 & 100,00 \\
\hline
\end{tabular}

Fonte: SÃO PAULO (Município). Relatórios técnicos da Secretaria da Saúde. 


\subsection{Condição do Local}

As porcentagens de amostras inaceitáveis nos primeiros anos de operação do sistema tiveram pronunciada influência sobre a adequação (ou inadequação) dos locais.

Nas tabelas de número 36 a 45 apresentam-se, para cada ano no período 1990-1999, as quantidades de locais com teores de flúor adequado e inadequado.

Tabela 36. Classificação dos locais segundo o teor de flúor nas águas de abastecimento público. São Paulo, SP, Brasil, 1990.

\begin{tabular}{ccc}
\hline CONDIÇÃO DO LOCAL & $\mathrm{N}$ & $\%$ \\
\hline Adequada & 44 & 73,3 \\
Inadequada & 16 & 26,7 \\
Sem Informação & - & - \\
\hline TOTAL & 60 & 100,0 \\
\hline
\end{tabular}

Fonte: SÃO PAULO (Município). Secretaria Municipal da Saúde (1991). 
Tabela 37. Classificação dos locais segundo o teor de flúor nas águas de abastecimento público. São Paulo, SP, Brasil, 1991.

\begin{tabular}{ccc}
\hline CONDIÇÃO DO LOCAL & $\mathrm{N}$ & $\%$ \\
\hline Adequada & 39 & 65,0 \\
Inadequada & 17 & 28,3 \\
Sem Informação & 4 & 6,7 \\
\hline TOTAL & 60 & 100,0
\end{tabular}

Fonte: SÃO PAULO (Município). Secretaria Municipal da Saúde (1992).

Tabela 38. Classificação dos locais segundo o teor de flúor nas águas de abastecimento público. São Paulo, SP, Brasil, 1992.

\begin{tabular}{ccc}
\hline CONDIÇÃO DO LOCAL & $\mathrm{N}$ & $\%$ \\
\hline Adequada & 34 & 56,7 \\
Inadequada & 21 & 35,0 \\
Sem Informação & 5 & 8,3 \\
\hline TOTAL & 60 & 100,0 \\
\hline
\end{tabular}

Fonte: SÃO PAULO (Município). Secretaria Municipal da Saúde (1993). 
Tabela 39. Classificação dos locais segundo o teor de flúor nas águas de abastecimento público. São Paulo, SP, Brasil, 1993 (janeiro a outubro).

\begin{tabular}{ccc}
\hline CONDIÇÃO DO LOCAL & $\mathrm{N}$ & $\%$ \\
\hline Adequada & 52 & 83,9 \\
Inadequada & - & - \\
Sem Informação & 10 & 16,1 \\
\hline TOTAL & 62 & 100,0
\end{tabular}

Fonte: SÃO PAULO (Município). Secretaria Municipal da Saúde (1994).

Tabela 40. Classificação dos locais segundo o teor de flúor nas águas de abastecimento público. São Paulo, SP, Brasil, 1994.

\begin{tabular}{ccc}
\hline CONDIÇÃO DO LOCAL & $\mathrm{N}$ & $\%$ \\
\hline Adequada & 52 & 83,9 \\
Inadequada & 1 & 1,6 \\
Sem Informação & 9 & 14,5 \\
\hline TOTAL & 62 & 100,0 \\
\hline
\end{tabular}

Fonte: SÃO PAULO (Município). Secretaria Municipal da Saúde (1995). 
Tabela 41. Classificação dos locais segundo o teor de flúor nas águas de abastecimento público. São Paulo, SP, Brasil, 1995.

\begin{tabular}{ccc}
\hline CONDIÇÃO DO LOCAL & $\mathrm{N}$ & $\%$ \\
\hline Adequada & 42 & 67,7 \\
Inadequada & - & - \\
Sem Informação & 20 & 32,3 \\
\hline TOTAL & 62 & 100,0
\end{tabular}

Fonte: SÃO PAULO (Município). Secretaria Municipal da Saúde (1996).

Tabela 42. Classificação dos locais segundo o teor de flúor nas águas de abastecimento público. São Paulo, SP, Brasil, 1996.

\begin{tabular}{ccc}
\hline CONDIÇÃO DO LOCAL & $\mathrm{N}$ & $\%$ \\
\hline Adequada & 35 & 56,5 \\
Inadequada & - & - \\
Sem Informação & 27 & 43,5 \\
\hline TOTAL & 62 & 100,0 \\
\hline
\end{tabular}

Fonte: SÃO PAULO (Município). Secretaria Municipal da Saúde (1997). 
Tabela 43. Classificação dos locais segundo o teor de flúor nas águas de abastecimento público. São Paulo, SP, Brasil, 1997.

\begin{tabular}{ccc}
\hline CONDIÇÃO DO LOCAL & $\mathrm{N}$ & $\%$ \\
\hline Adequada & 61 & 96,8 \\
Inadequada & - & - \\
Sem Informação & 2 & 3,2 \\
\hline TOTAL & 63 & 100,0 \\
\hline
\end{tabular}

Fonte: SÃO PAULO (Município). Secretaria Municipal da Saúde (1998).

Tabela 44. Classificação dos locais segundo o teor de flúor nas águas de abastecimento público. São Paulo, SP, Brasil, 1998.

\begin{tabular}{ccc}
\hline CONDIÇÃO DO LOCAL & $\mathrm{N}$ & $\%$ \\
\hline Adequada & 61 & 96,8 \\
Inadequada & - & - \\
Sem Informação & 2 & 3,2 \\
\hline TOTAL & 63 & 100,0 \\
\hline
\end{tabular}

Fonte: SÃO PAULO (Município). Secretaria Municipal da Saúde (1999). 
Tabela 45. Classificação dos locais segundo o teor de flúor nas águas de abastecimento público. São Paulo, SP, Brasil, 1999.

\begin{tabular}{ccc}
\hline CONDIÇÃO DO LOCAL & $\mathrm{N}$ & $\%$ \\
\hline Adequada & 61 & 96,8 \\
Inadequada & - & - \\
Sem Informação & 2 & 3,2 \\
\hline TOTAL & 63 & 100,0 \\
\hline
\end{tabular}

Fonte: SÃO PAULO (Município). Secretaria Municipal da Saúde (2000).

Observa-se (Figura 2) que em 1990 apenas 73,3\% dos locais foram considerados adequados. Essa proporção caiu para 65,0\% em 1991 e ficou ainda pior em 1992, com apenas $56,7 \%$ dos locais sendo considerados adequados. Porcentagem igualmente baixa $(56,5 \%)$ de locais adequados foi registrada em 1996.

A Figura 2 mostra também um significativo crescimento do número de locais sem informação (menos de 9 amostras colhidas no ano): de 6,7\% em 1991 a porcentagem aumentou para 8,3\% em 1992; 16,1\% em 1993, caindo para 14,5\% em 1994. Em 1995 essa porcentagem mais que dobrou, chegando a $32,3 \%$ e, num crescendo expressivo, atingiu $43,5 \%$ em 1996. A partir de 
1997 detecta-se significativa mudança nos números. A porcentagem de locais sem informação caiu para 3,2\%, mantendo-se esta porcentagem nos anos de 1997 e 1998. Os locais adequados corresponderam, nos anos de 1997, 1998 e 1999, segundo os documentos oficiais, a $96,8 \%$.

Figura 2
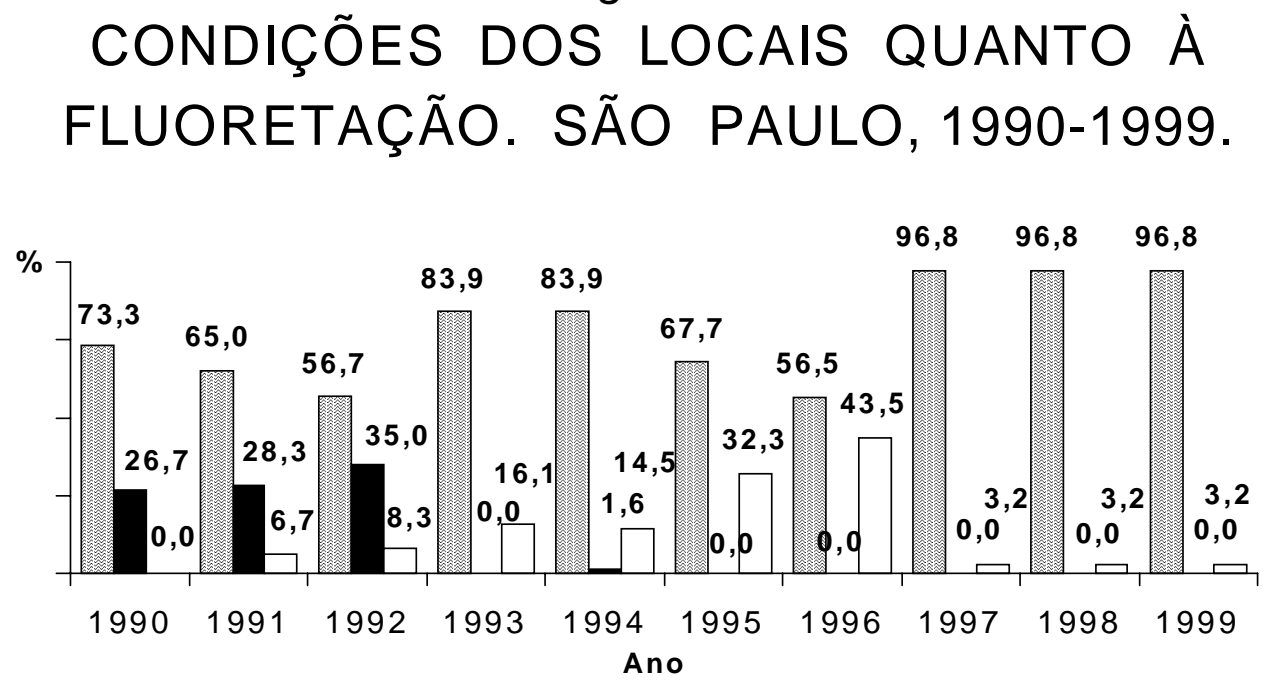

图 ADEQUADO —INADEQUADO $\square$ SEM INFORMAÇÃO

Nas Figuras de número 3 a 65 estão apresentadas as freqüências com que diferentes teores de flúor ocorreram nas águas coletadas nos 63 pontos que integram o sistema de vigilância, no período desta investigação. 
Fig ura 3.

TEORES DE FLÚOR (EM p pm) EM ÁGUAS COLETADAS NO

PAM J. B. MAGALDI. SÃO PAULO, SP, 1990-1999.

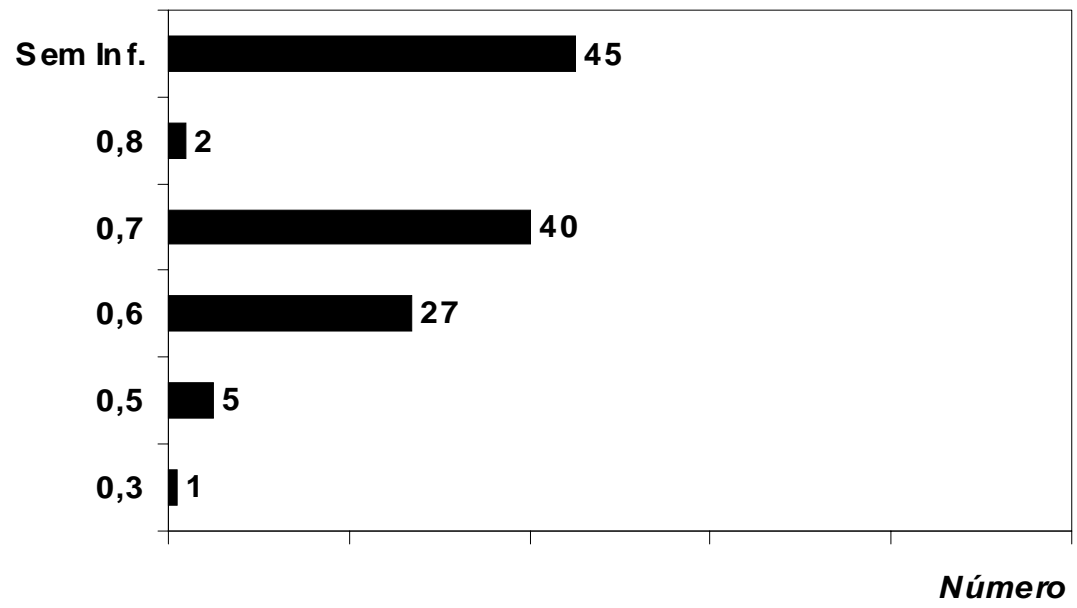

Figura 4.

TEORES DE FLÚOR (EM ppm) EM ÁGUAS COLETADAS NO PAM CAMBUCI. SÃO PAULO, SP, 1990-1999.

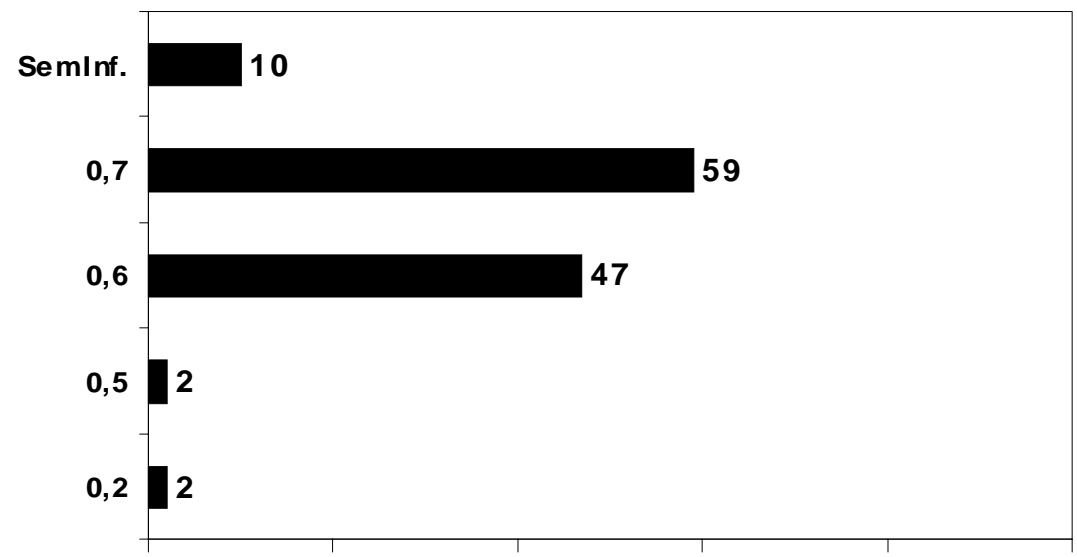

Número 
Figura 5.

TEORES DE FLÚOR (EM ppm) EM ÁGUAS COLETADAS NO HOSPITAL MUNICIPAL MENINO JESUS. SÃO PAULO, SP, 1990-1999.

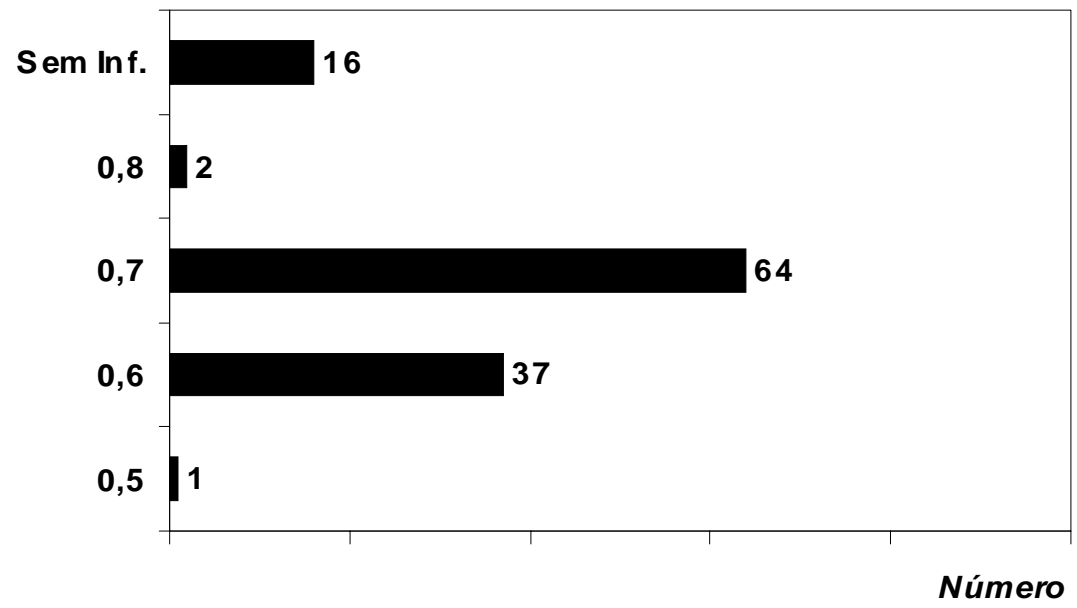

Figura 6.

TEORES DE FLÚOR (EM ppm) EM ÁGUAS COLETADAS NA CLÍNICA HUMATÁ. SÃO PAULO, SP, 1990-1999.

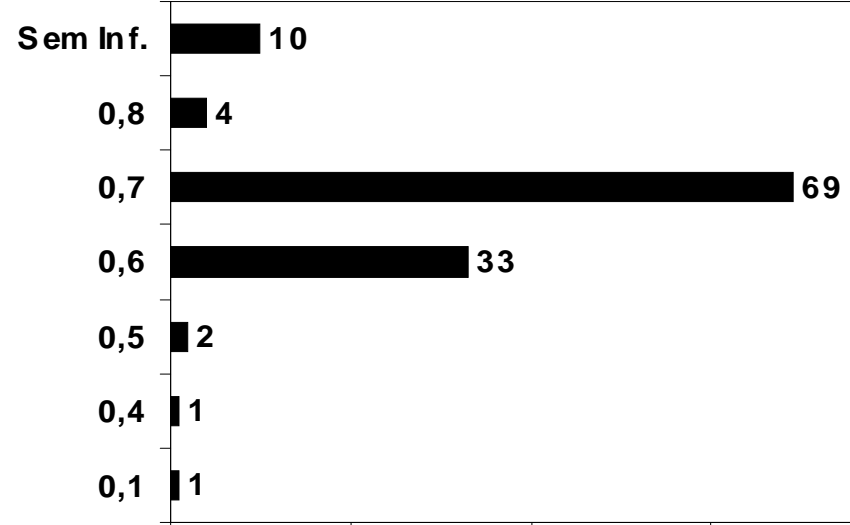

Número 
Figura 7.

TEORES DE FLÚOR (EM ppm) EM ÁGUAS COLETADAS NA EMPG INFANTE D. HENRIQUE. SÃO PAULO, SP, 1990-1999.

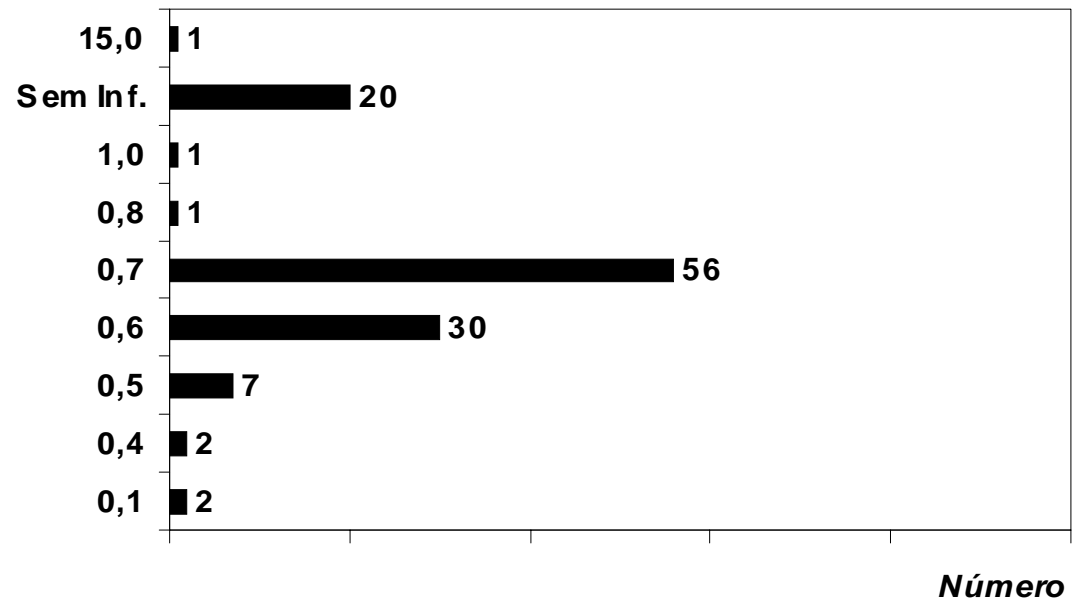

Figura 8.

TEORES DE FLÚOR (EM ppm) EM ÁGUAS COLETADAS NO PS BARRA FUNDA. SÃO PAULO, SP, 1990-1999.

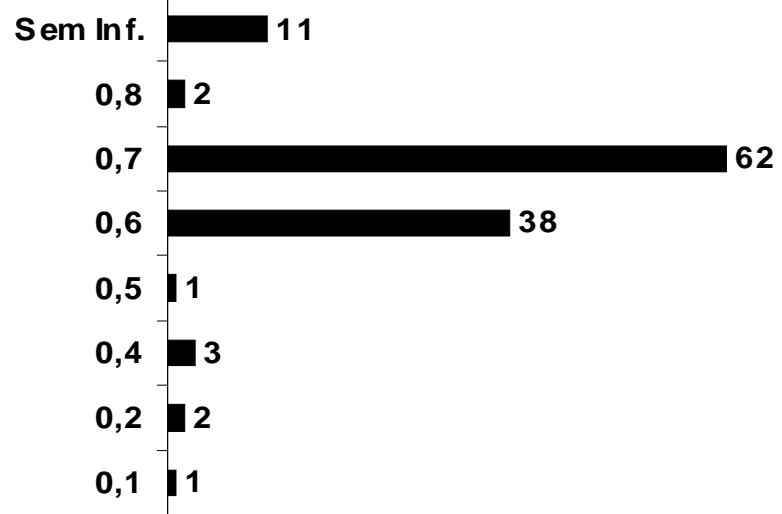

Número 
Figura 9.

TEORES DE FLÚOR (EM ppm) EM ÁGUAS COLETADAS NO PAM VILA ROMANA. SÃO PAULO, SP, 1990-1999.

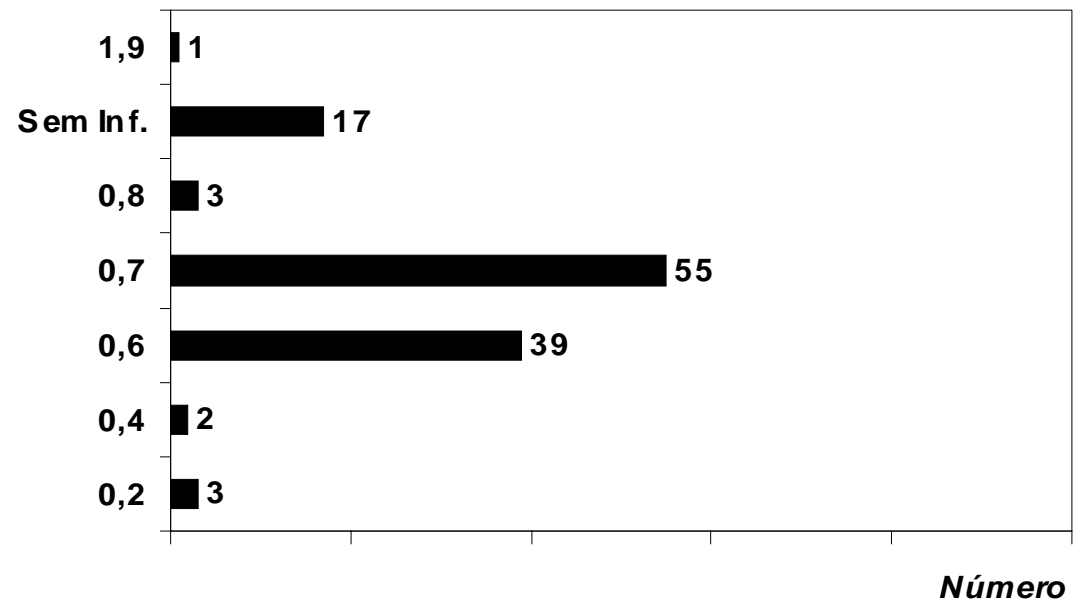

Figura 10.

TEORES DE FLÚOR (EM ppm) EM ÁGUAS COLETADAS NA EMPG DILERMANDO D. SANTOS. SÃO PAULO, SP, 1990-1999.

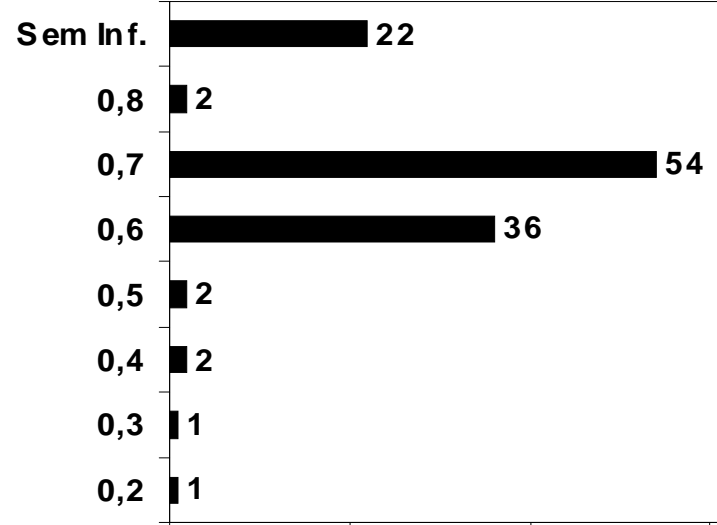

Número 
Figura 11.

TEORES DE FLÚOR (EM ppm) EM ÁGUAS COLETADAS NO

PAM VLA NOVA JAGUARÉ. SÃO PAULO, SP, 1990-1999.

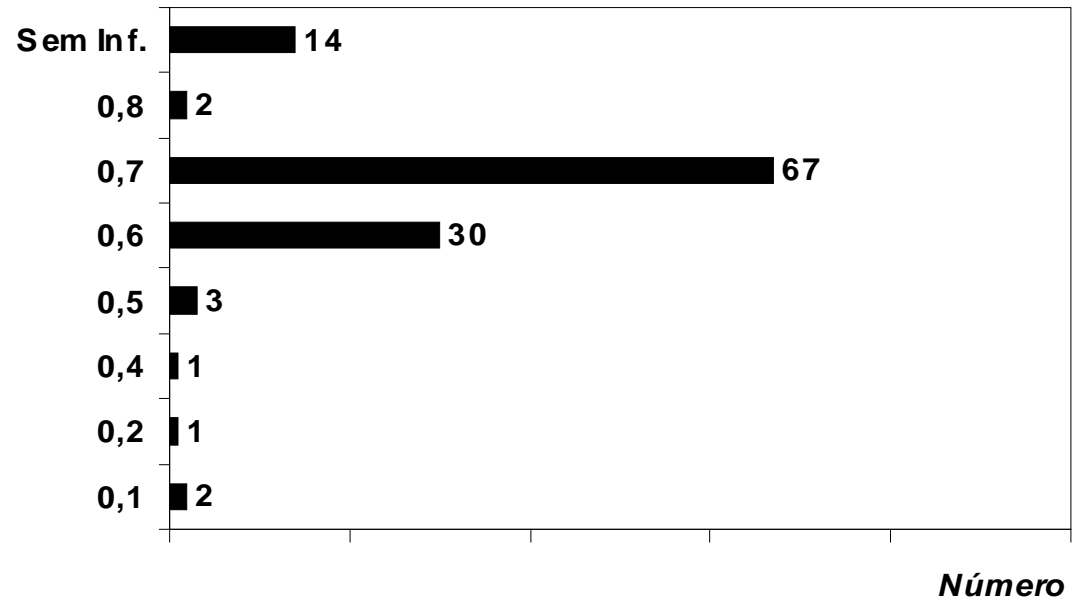

Figura 12.

TEORES DE FLÚOR (EM ppm) EM ÁGUAS COLETADAS NA UBS JARDIM D’ABRIL. SÃO PAULO, SP, 1990-1999.

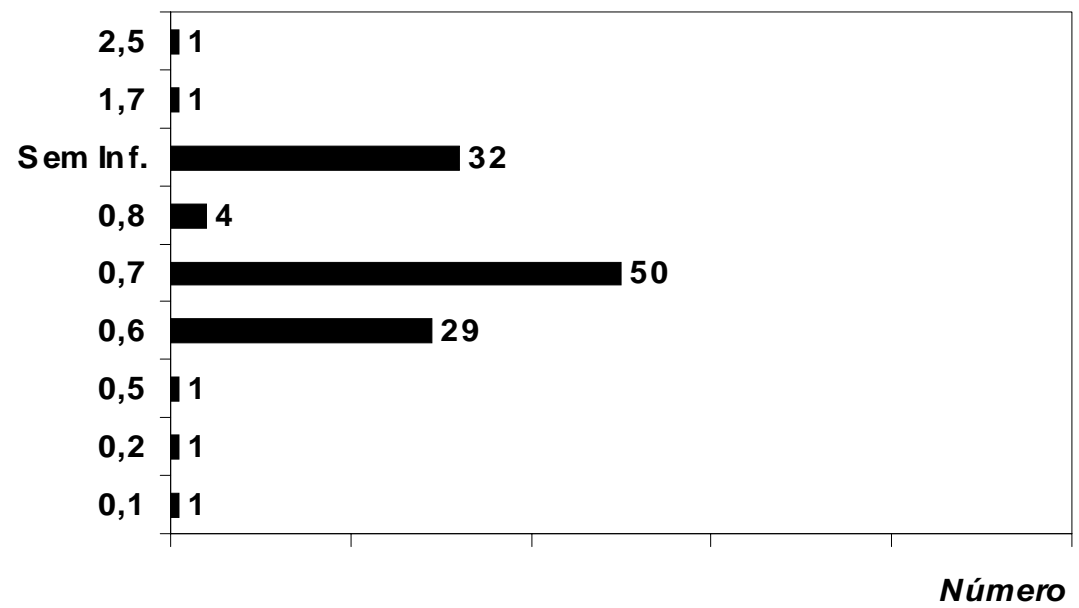


Figura 13.

TEORES DE FLÚOR (EM ppm) EM ÁGUAS COLETADAS NO PAM SÃO JORGE. SÃO PAULO, SP, 1990-199 9.

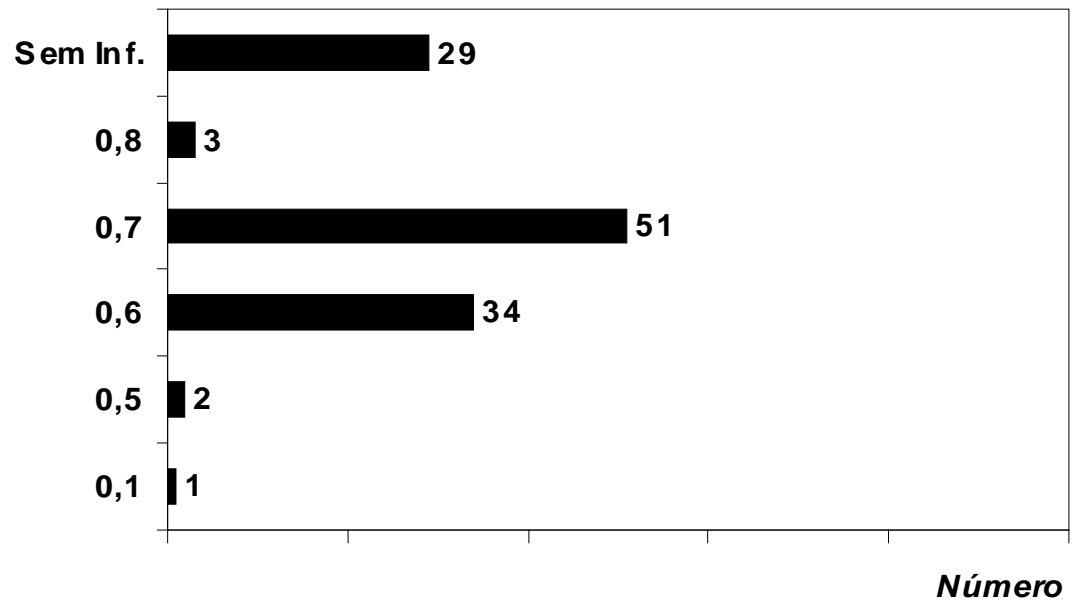

Figura 14.

TEORES DE FLÚOR (EM ppm) EM ÁGUAS COLETADAS NA UBS JARDIM JAQUEUNE. SÃO PAULO, SP, 1990-1999.

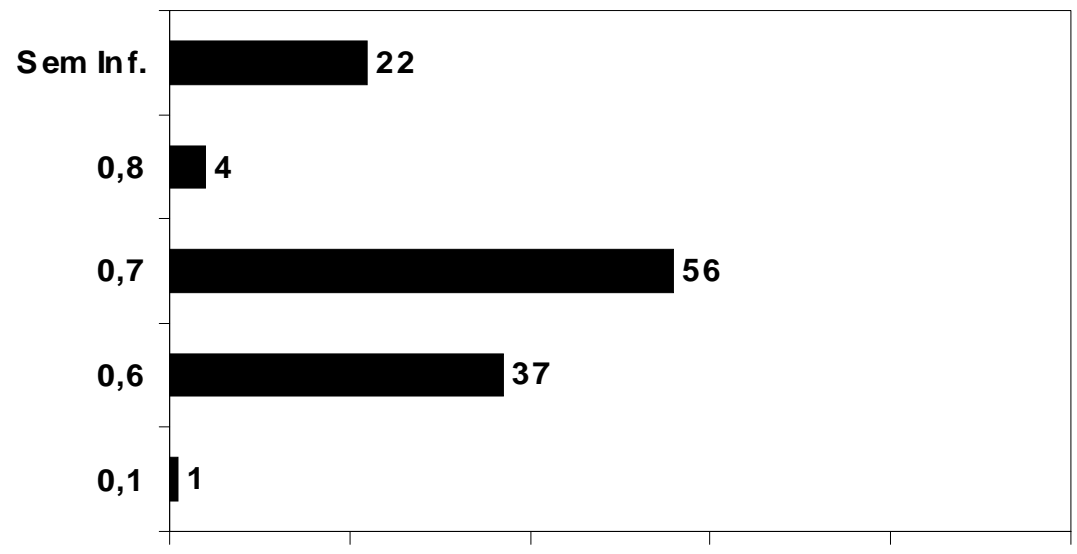

Número 
Figura 15.

TEORES DE FLÚOR (EM ppm) EM ÁGUAS COLETADAS NO

PAM J OAQUIM ROSSINI. SÃO PAULO, SP, 1990-1999.

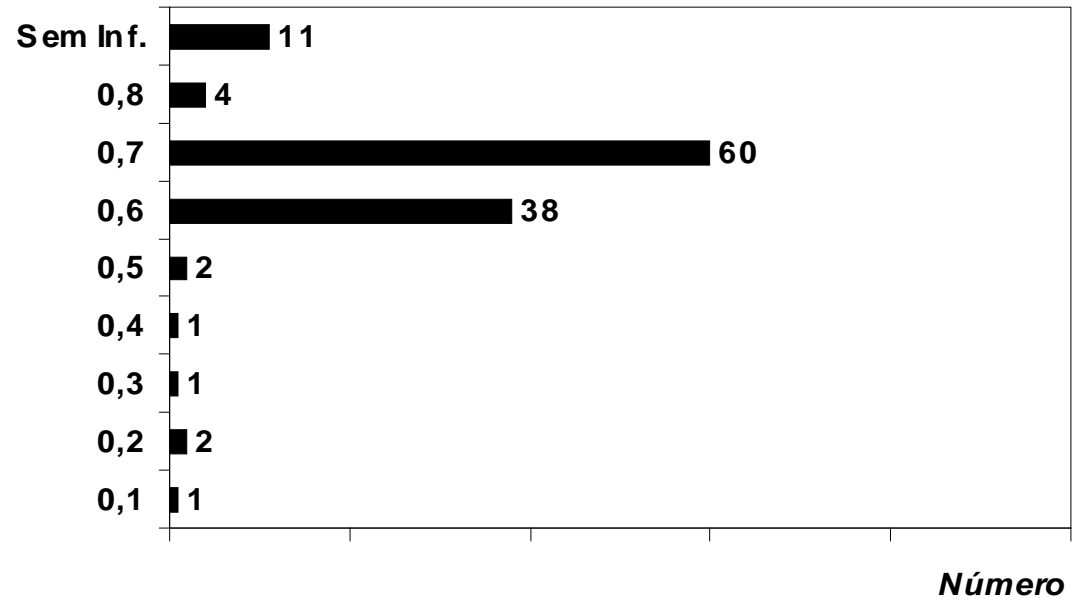

Figura 16.

TEORES DE FLÚOR (EM ppm) EM Á GUAS COLETADAS NO PAM DR. LUIZ E. MAZZONI. SÃO PAULO, SP, 1990-1999.

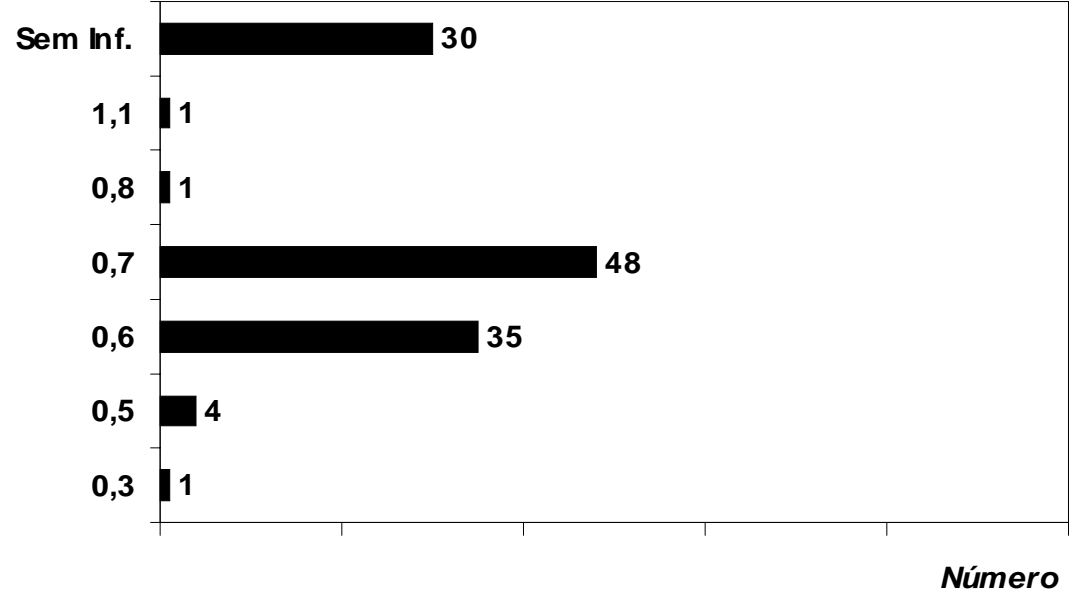


Figura 17.

TEORES DE FLÚOR (EM ppm) EM ÁGUAS COLETADAS NO PAM GERALDO S. FERREIRA. SÃO PAULO, SP, 1990-199 9.

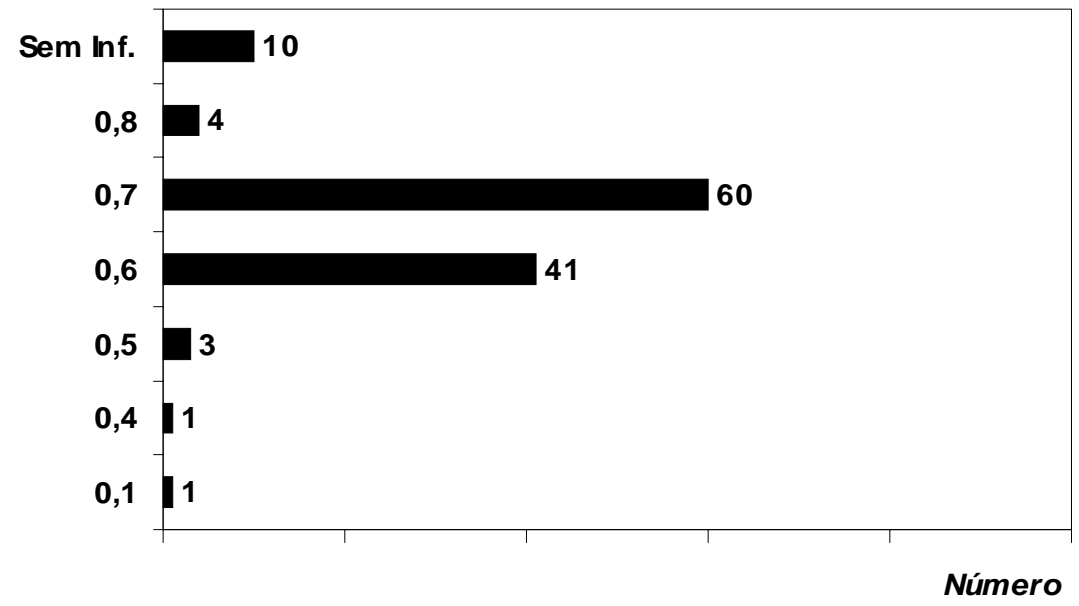

Figura 18.

TEORES DE FLÚOR (EM ppm) EM ÁGUAS COLETADAS NO

PAM TEOTÔNIO VILELA. SÃO PAULO, SP, 1990-1999.

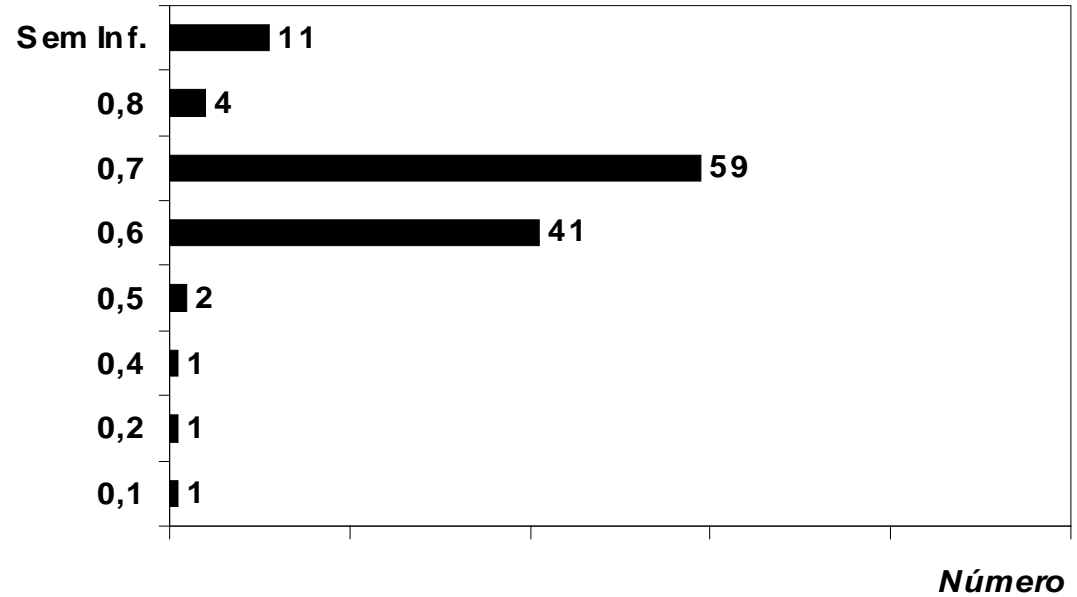


Figura 19.

TEORES DE FLÚOR (EM ppm) EM ÁGUAS COLETADAS NA UBS JARDIM ELBA. SÃO PAULO, SP, 1990-1999.

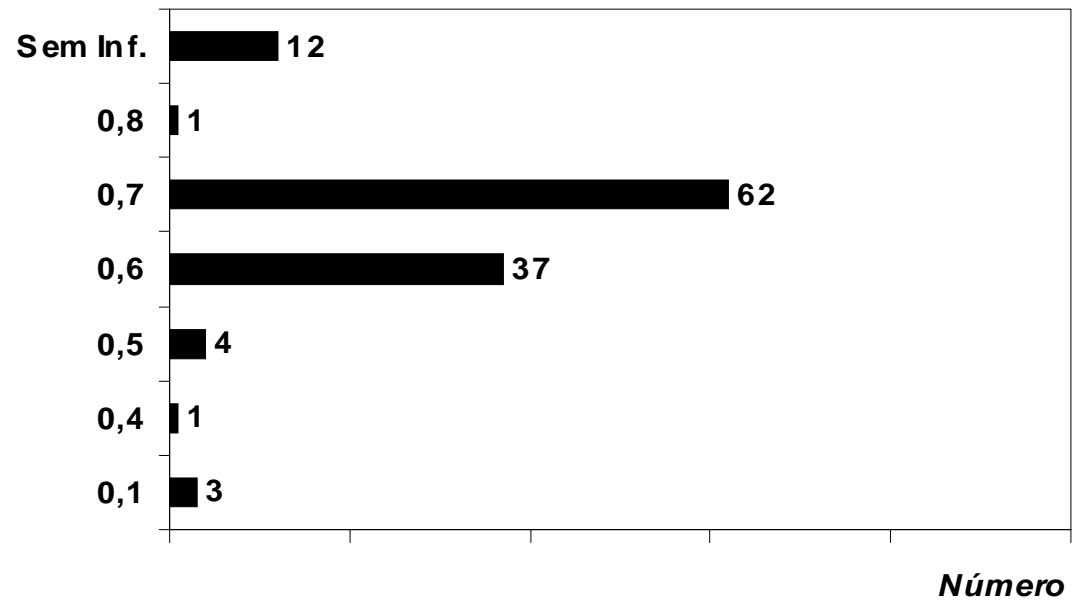

Figura 20.

TEORES DE FLÚOR (EM ppm) EM ÁGUAS COLETADAS NA UBS H. MORBINJR. SÃO PAULO, SP, 1990-1999.

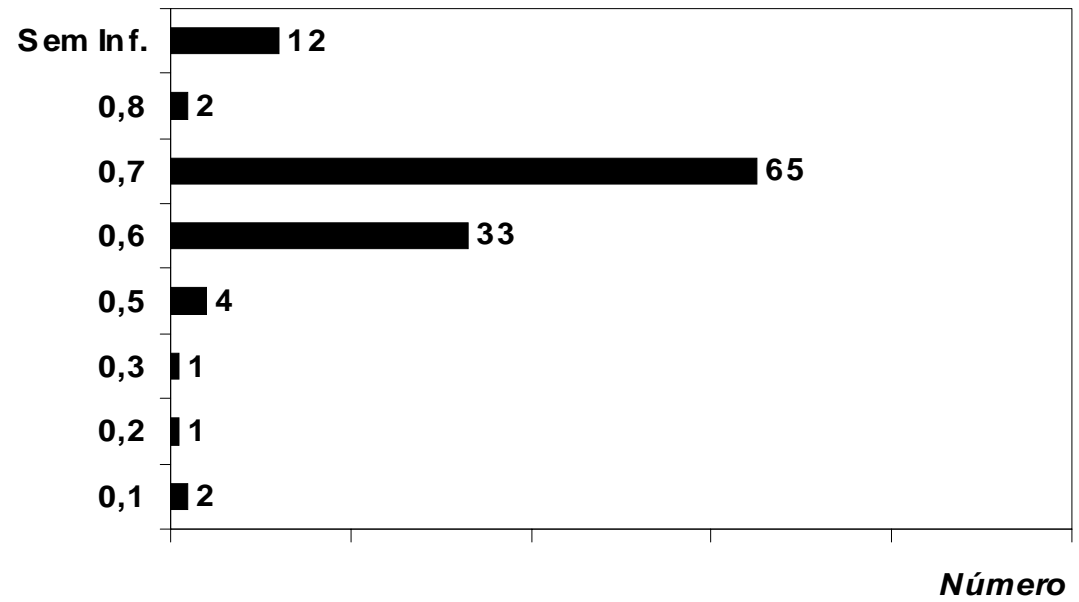


Figura 21.

TEORES DE FLÚOR (EM ppm) EM ÁGUAS COLETADAS NA UBS VILA GUARANI. SÃO PAULO, SP, 1990-1999.

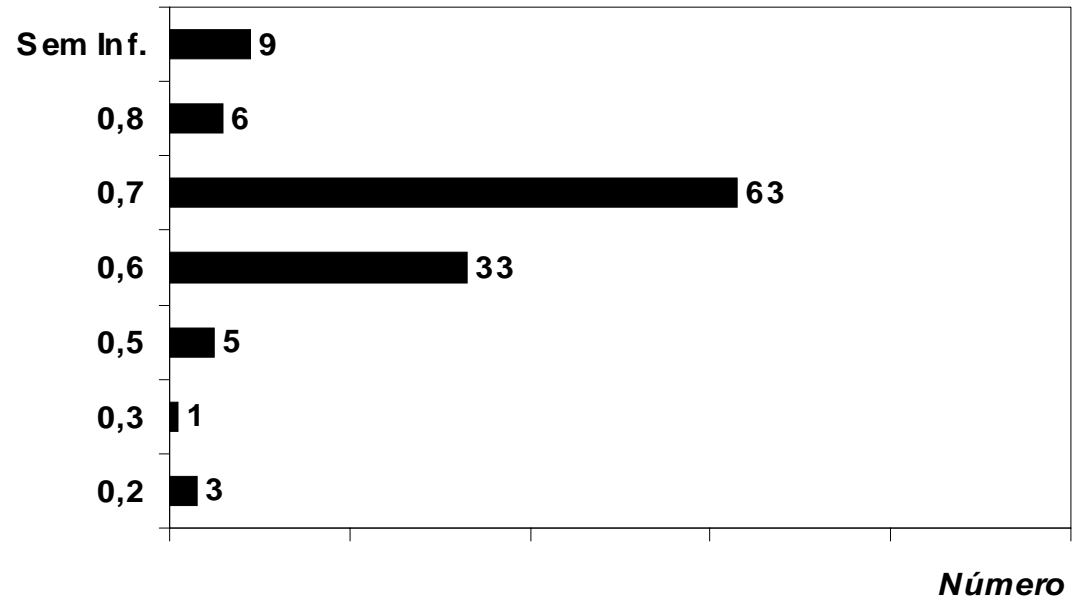

Figura 22.

TEORES DE FLÚOR (EM ppm) EM ÁGUAS COLETADAS NO PAM JARDIM S.FRANCISCO. SÃO PAULO, SP, 1990-199 9.

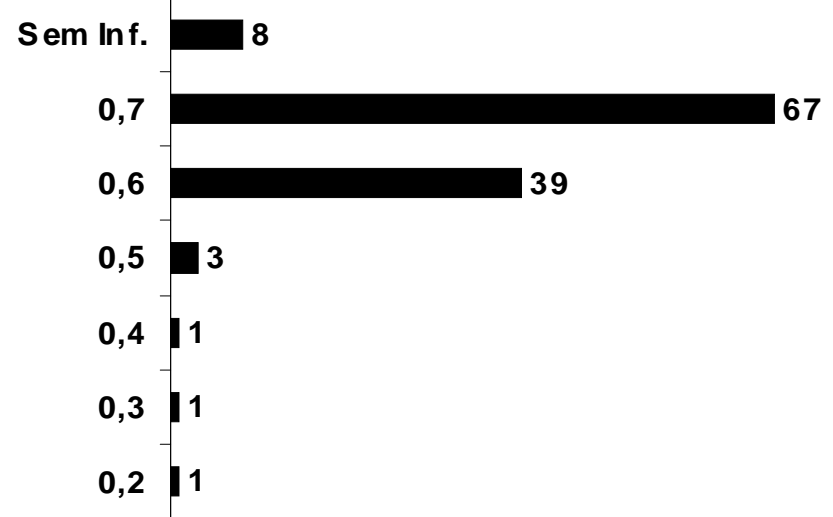

Número 
Figura 23.

TEORES DE FLÚOR (EM ppm) EM ÁGUAS COLETADAS NA UBS SANTA TEREZINHA. SÃO PAULO, SP, 1990-1999.

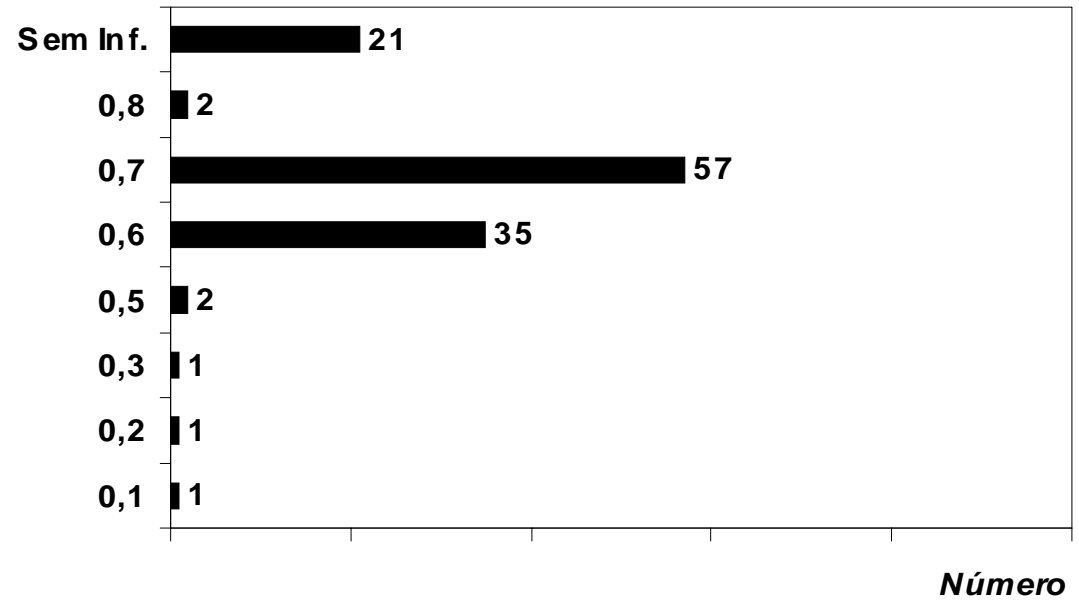

Figura 24.

TEORES DE FLÚOR (EM ppm) EM ÁGUAS COLETADAS NA UBS JARDIM ITAPEMA. SÃO PAULO, SP, 1990-1999.

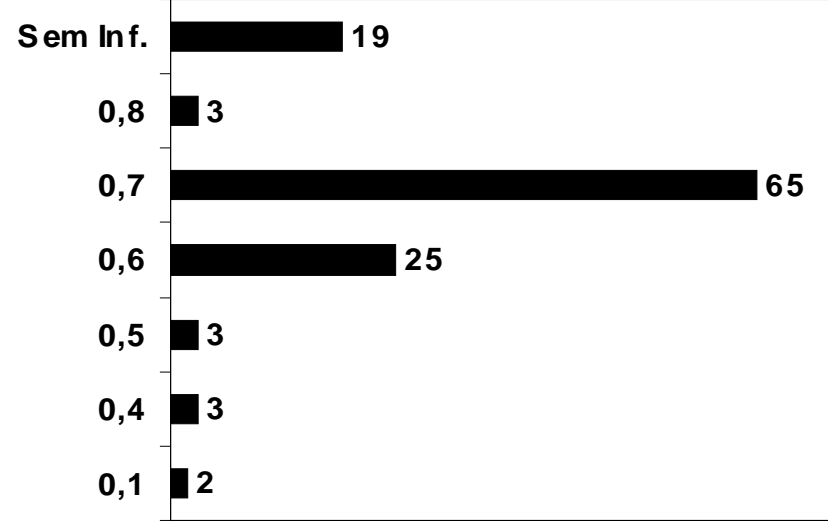

Número 
Figura 25.

TEORES DE FLÚOR (EM ppm) EM ÁGUAS COLETADAS NO

PAM PADRE J. ANCHIETA. SÃO PAULO, SP, 1990-1999.

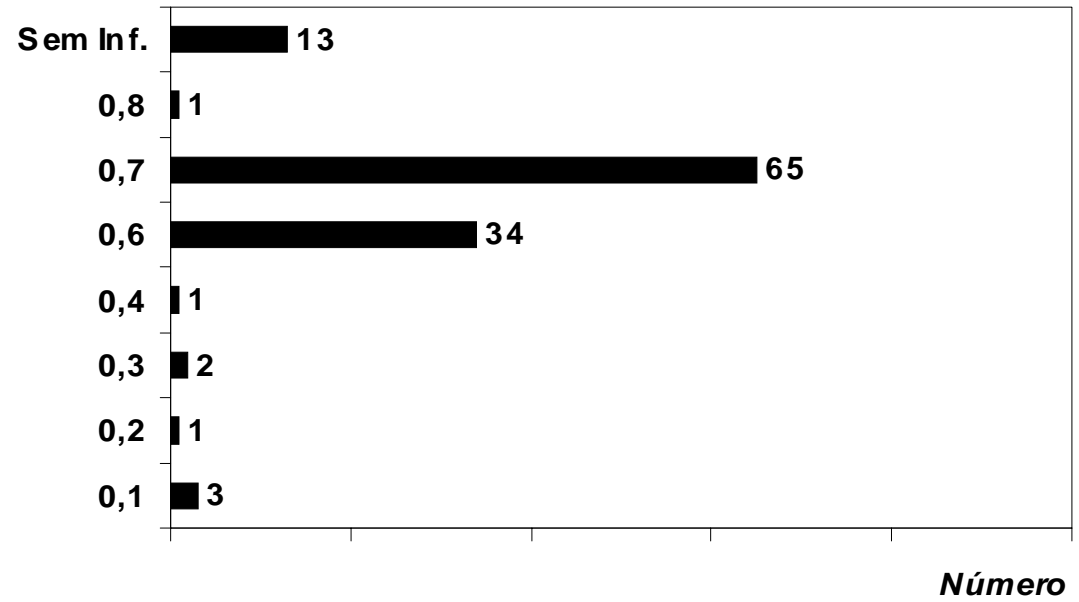

Figura 26.

TEORES DE FLÚOR (EM ppm) EM ÁGUAS COLETADAS NO PAM PADRE MANOEL DA NOBREGA. SÃO PAULO, SP, 1990-1999.

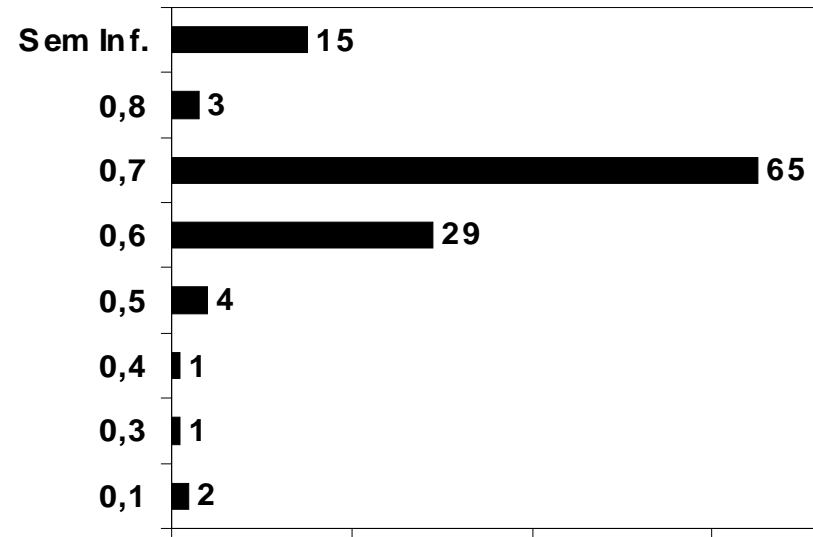

Número 
Figura 27.

TEORES DE FLÚOR (EM ppm) EM ÁGUAS COLETADAS NO PAM CASTRO ALVES. SÃO PAULO, SP, 1990-1999.

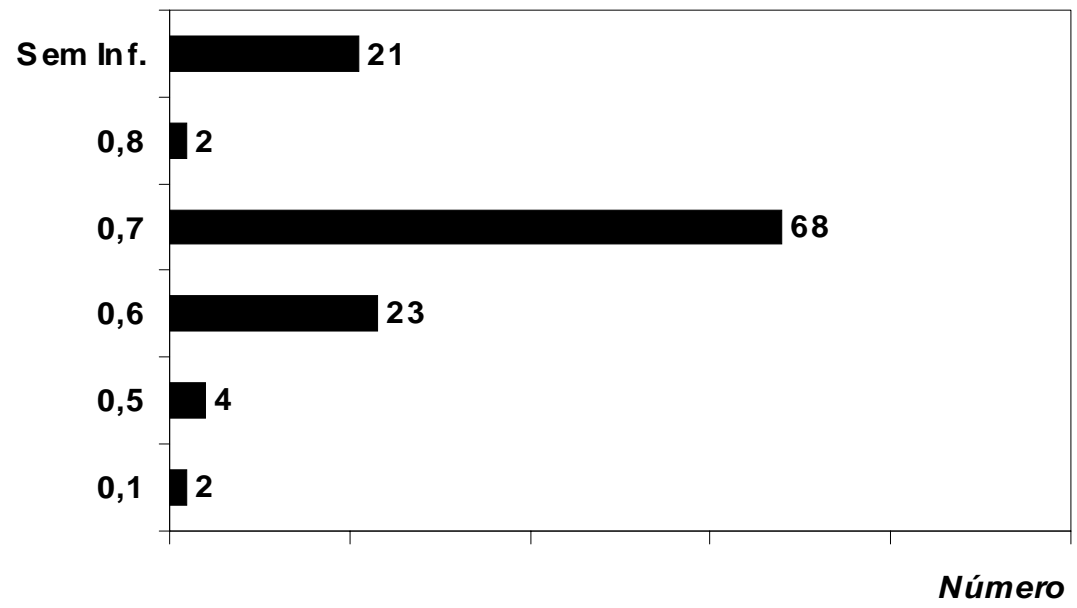

Figura 28.

TEORES DE FLÚOR (EM ppm) EM ÁGUAS COLETADAS NO PAM N.S. DO CARMO. SÃO PAULO, SP, 1990-1999.

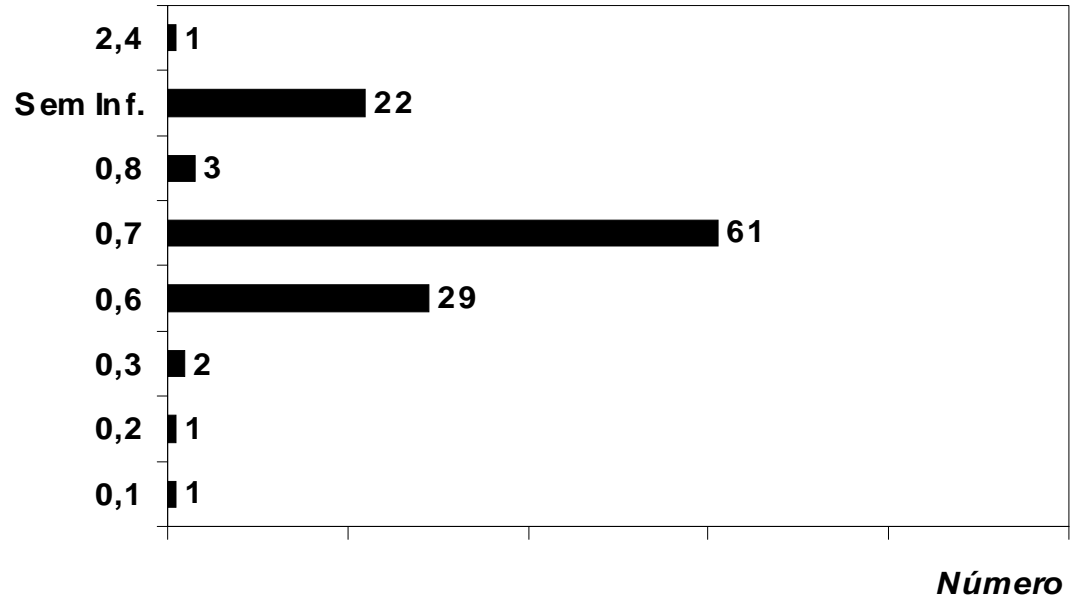


Figura 29.

TEORES DE FLÚOR (EM ppm) EM ÁGUAS COLETADAS NO

PAM CIDADE LÍDER. SÃO PAULO, SP, 1990-1999.

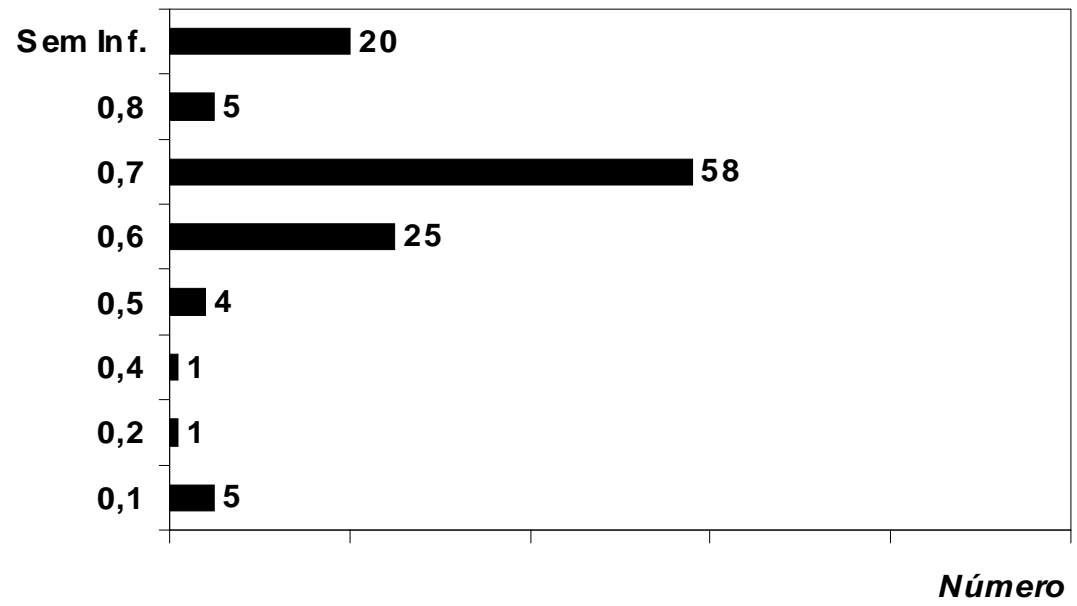

Figura 30.

TEORES DE FLÚOR (EM ppm) EM ÁGUAS COLETADAS NO

PAM JOSÉ BONIFÁCIO II. SÃO PAULO, SP, 1990-1999.

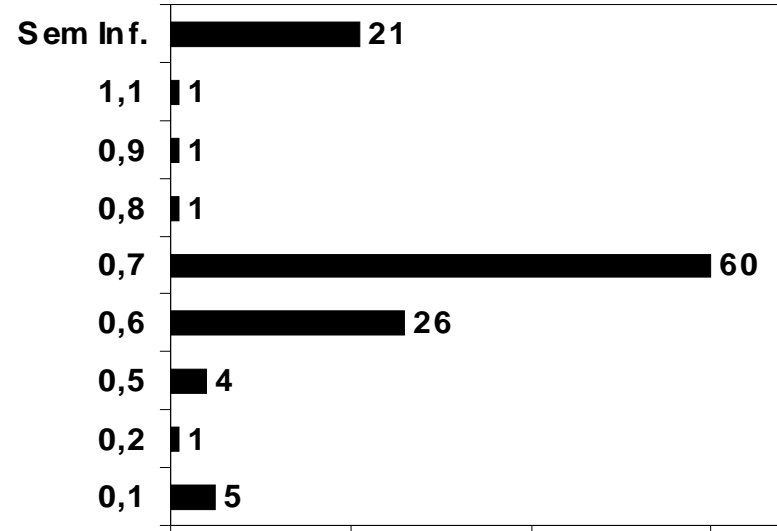

Número 
Figura 31.

TEORES DE FLÚOR (EM ppm) EM ÁGUAS COLETADAS NO

PAM VILA SANTANA. SÃO PAULO, SP, 1990-1999.

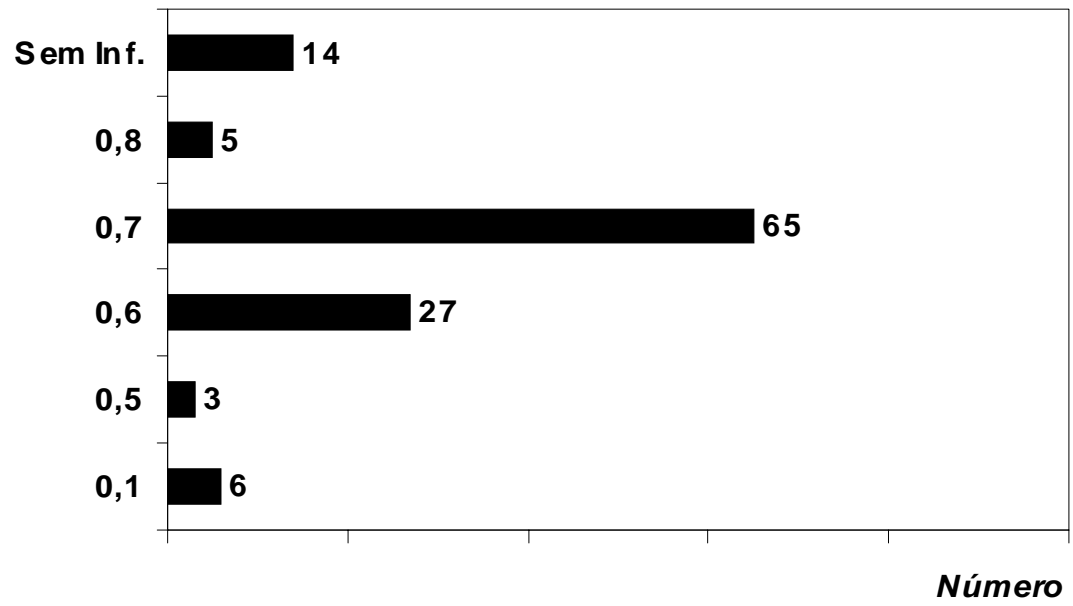

Figura 32.

TEORES DE FLÚOR (EM ppm) EM ÁGUAS COLETADAS NO PAM JARDIM TIETÊ. SÃO PAULO, SP, 1990-1999.

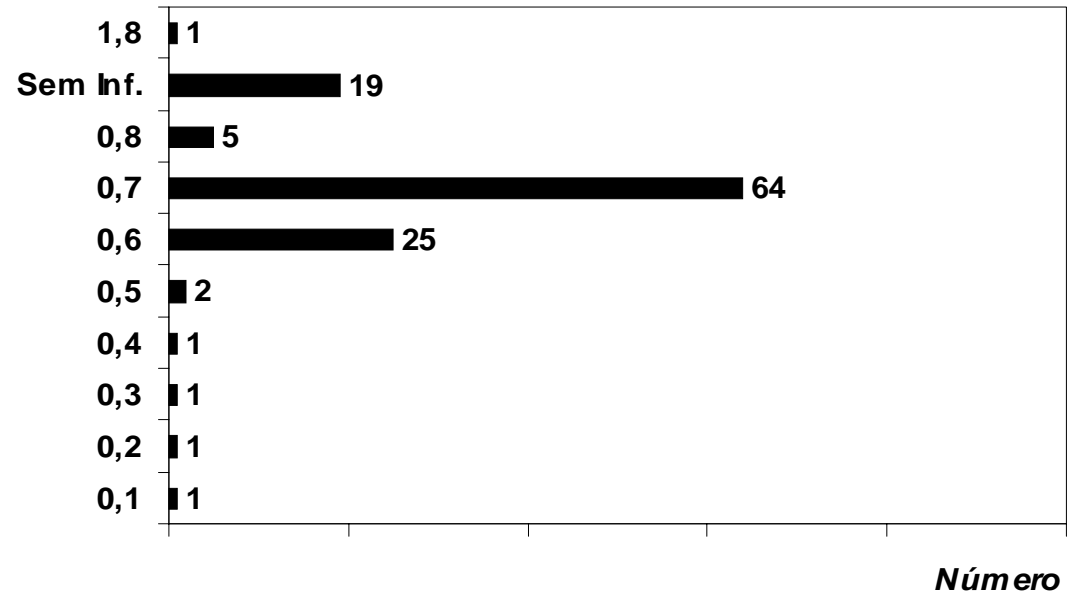


Figura 33.

TEORES DE FLÚOR (EM ppm) EM ÁGUAS COLETADAS NO PAM VILA CISPER. SÃO PAULO, SP, 1990-1999.

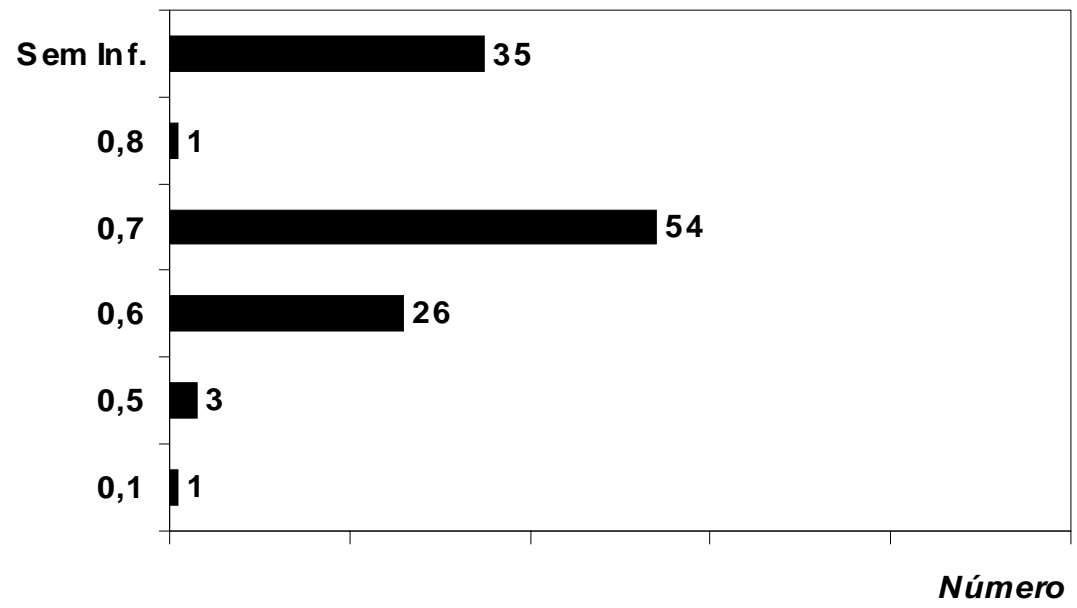

Figura 34.

TEORES DE FLÚOR (EM ppm) EM ÁGUAS COLETADAS NO PAM JARDIM HELENA. SÃO PAULO, SP, 1990-199 9.

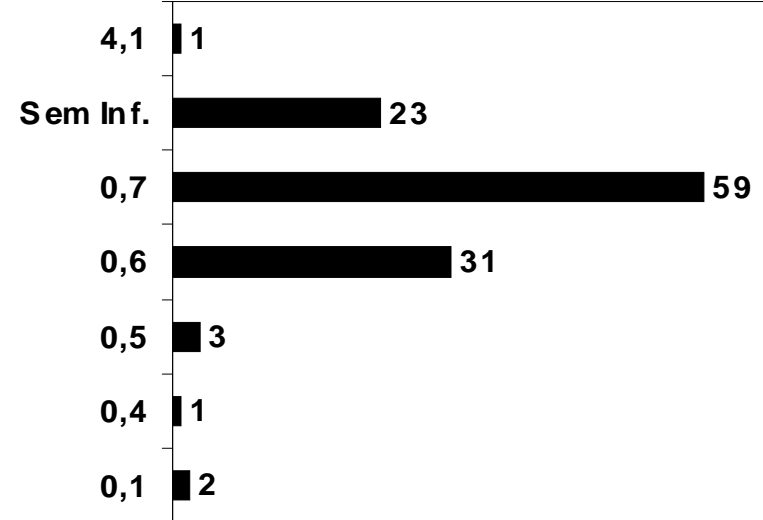

Número 
Figura 35.

TEORES DE FLÚOR (EM ppm) EM ÁGUAS COLETADAS NO

PAM PONTE RASA. SÃO PAULO, SP, 1990-1999.

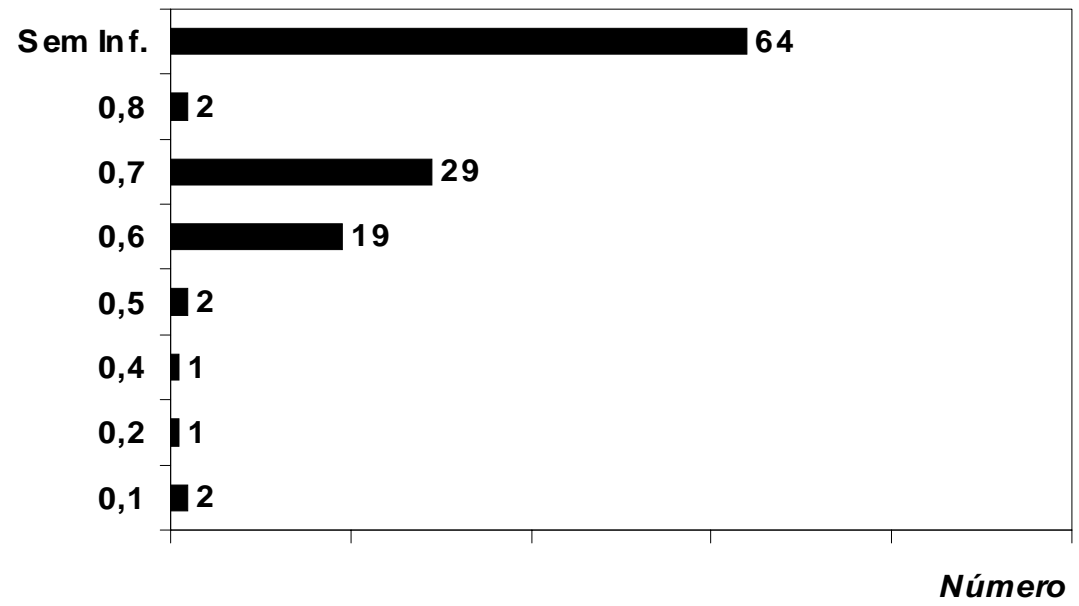

Figura 36.

TEORES DE FLÚOR (EM ppm) EM ÁGUAS COLETADAS NO PAM JARDIM MAIA. SÃO PAULO, SP, 1990-1999.

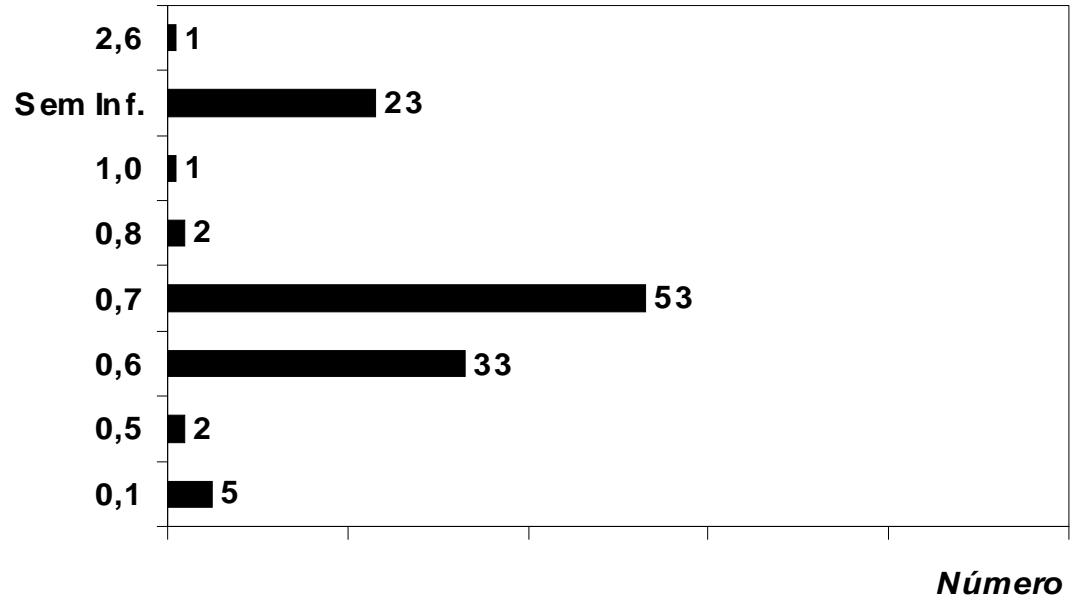


Figura 37.

TEORES DE FLÚOR (EM ppm) EM ÁGUAS COLETADAS NA UBS VILA RAMOS. SÃO PAULO, SP, 1990-1999.

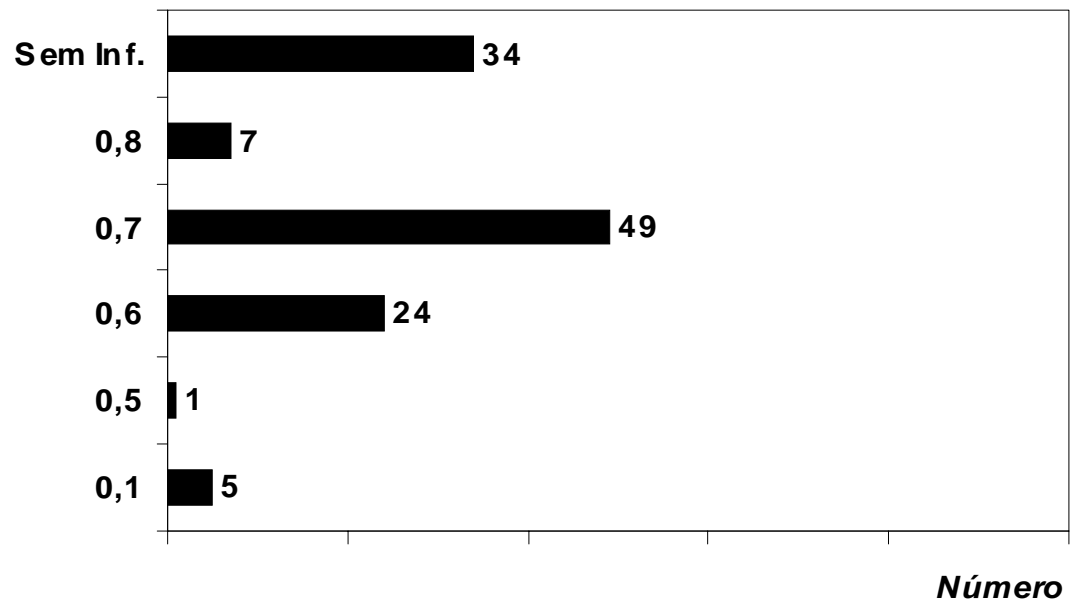

Figura 38.

TEORES DE FLÚOR (EM ppm) EM ÁGUAS COLETADAS NA UBS VILA JACUII. SÃO PAULO, SP, 1990-199 9.

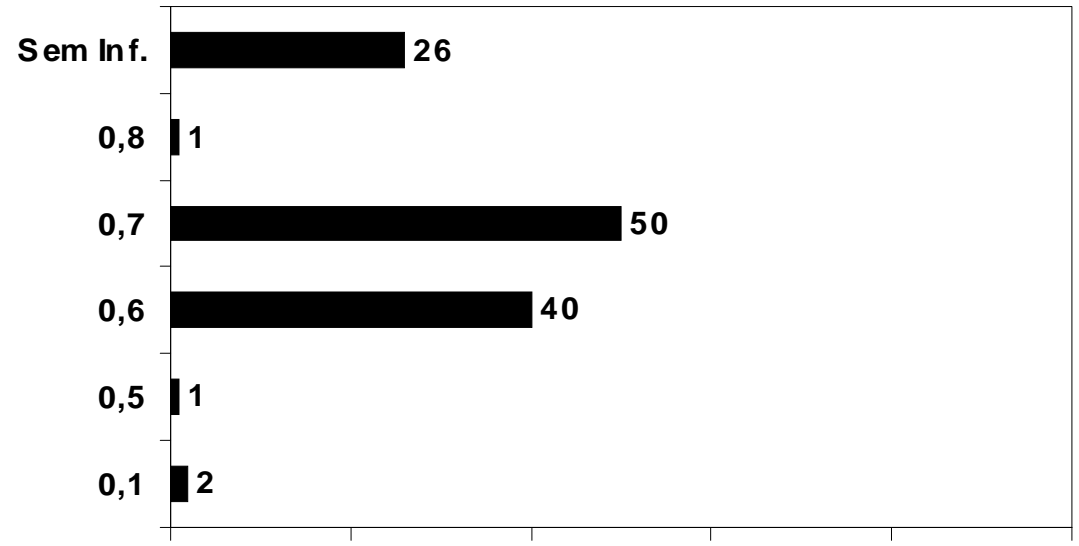

Número 
Figura 39.

TEORES DE FLÚOR (EM ppm) EM ÁGUAS COLETADAS NO PAM PARQUE NOVO MUNDO. SÃO PAULO, SP, 1990-1999.

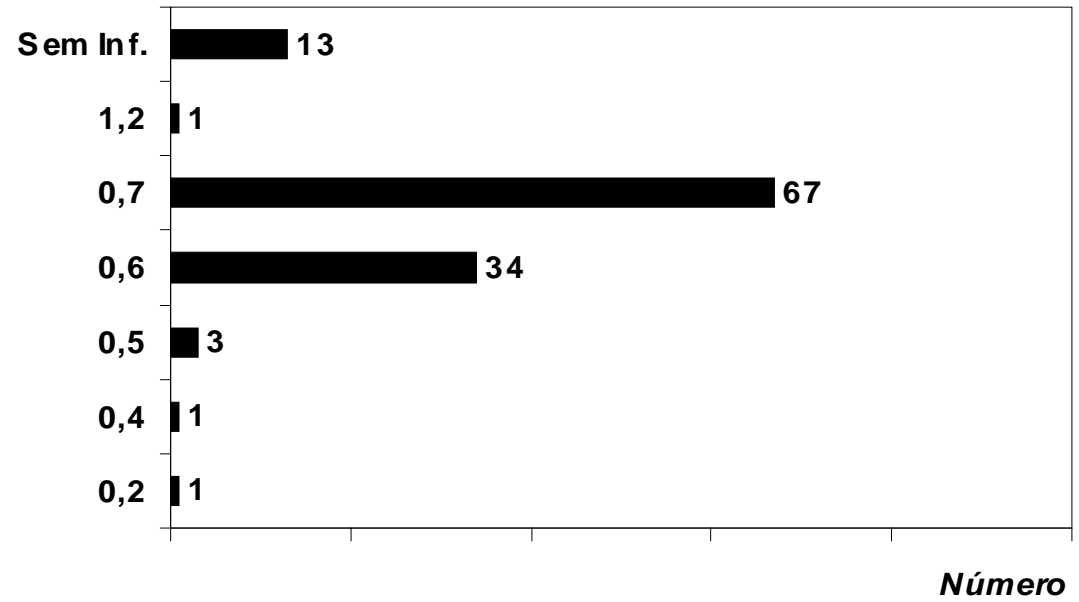

Figura 40.

TEORES DE FLÚOR (EM ppm) EM ÁGUAS COLETADAS NO VILA NOVA GALVÃO. SÃO PAULO, SP, 1990-199 9.

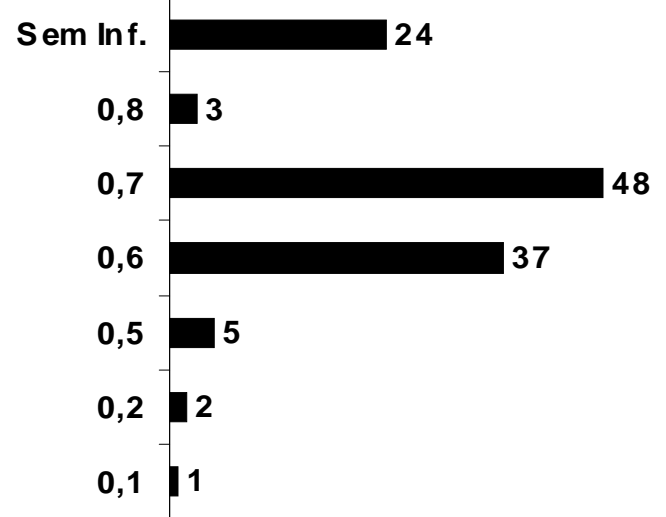

Número 
Figura 41.

TEORES DE FLÚOR (EM p pm) EM ÁGUAS COLETADAS NO

PAM JOAQUIM A. EIRADO. SÃO PAULO, SP, 1990-1999.

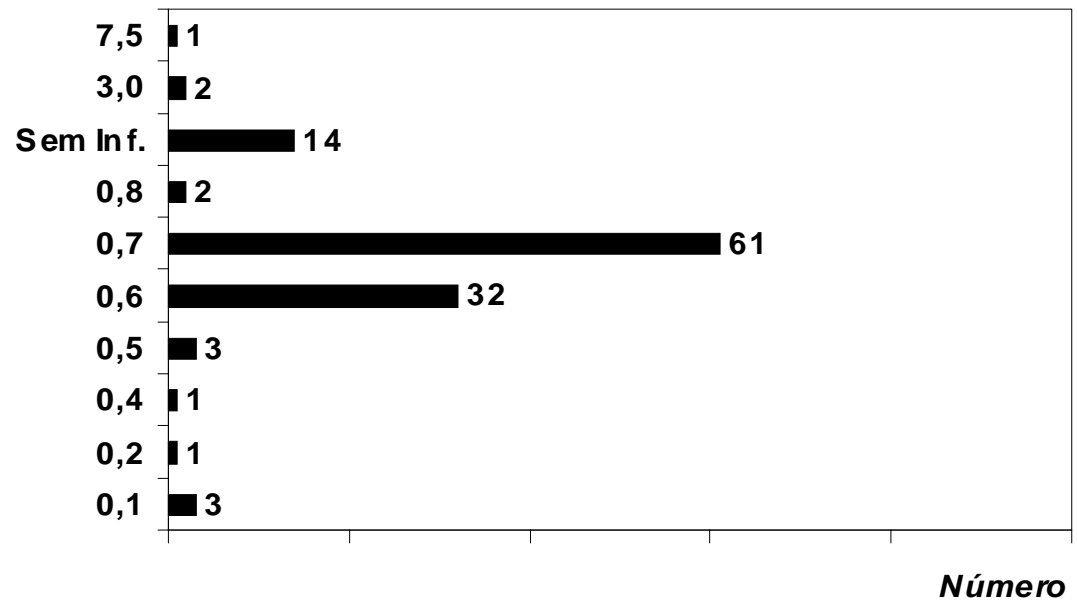

Figura 42.

TEORES DE FLÚOR (EM ppm) EM ÁGUAS COLETADAS NO JARDIM CAROMBÉ. SÃO PAULO, SP, 1990-1999.

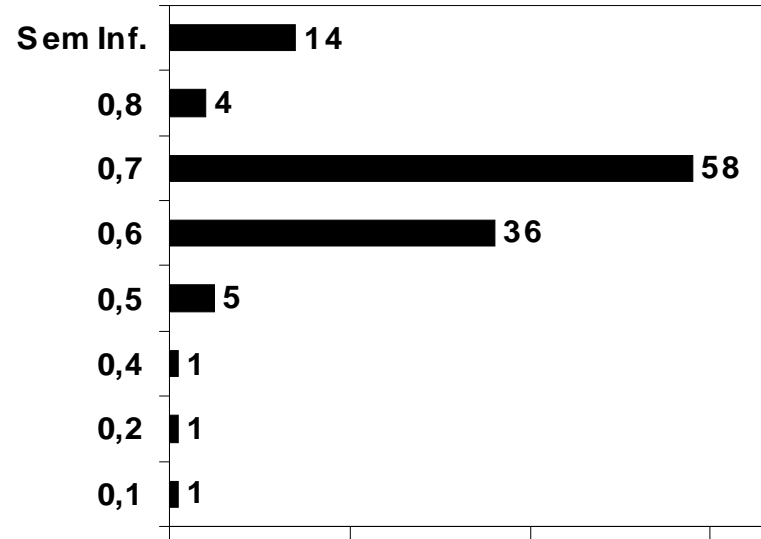

Número 
Figura 43.

TEORES DE FLÚOR (EM ppm) EM ÁGUAS COLETADAS NO PAM FREGUESIA DO Ó. SÃO PAULO, SP, 1990-1999.

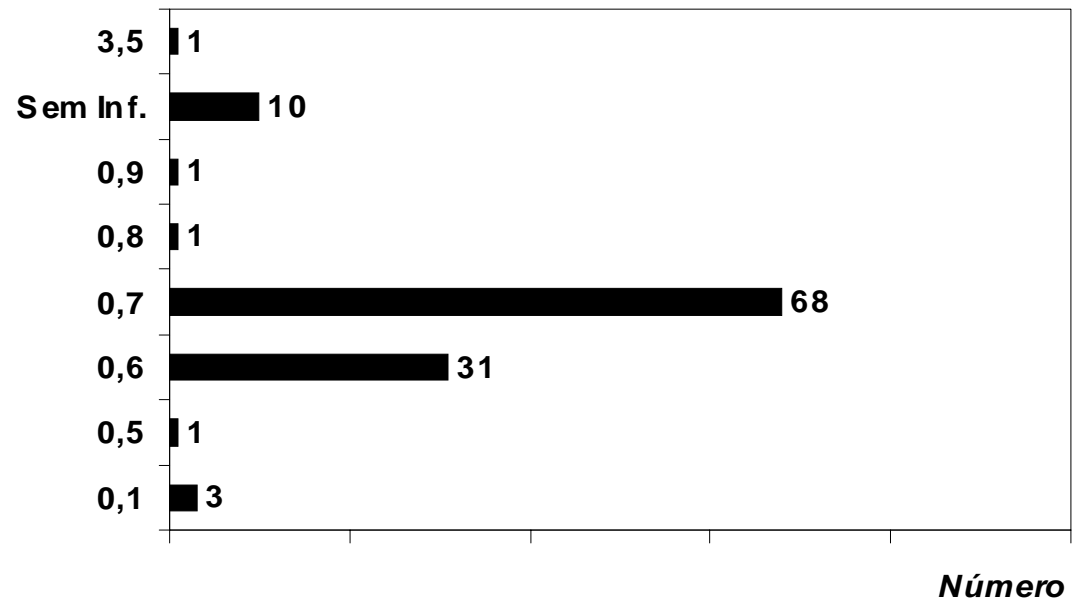

Figura 44.

TEORES DE FLÚOR (EM ppm) EM ÁGUAS COLETADAS NO PAM D. MARIQUINHA SCIACIA. SÃO PAULO, SP, 1990-1999.

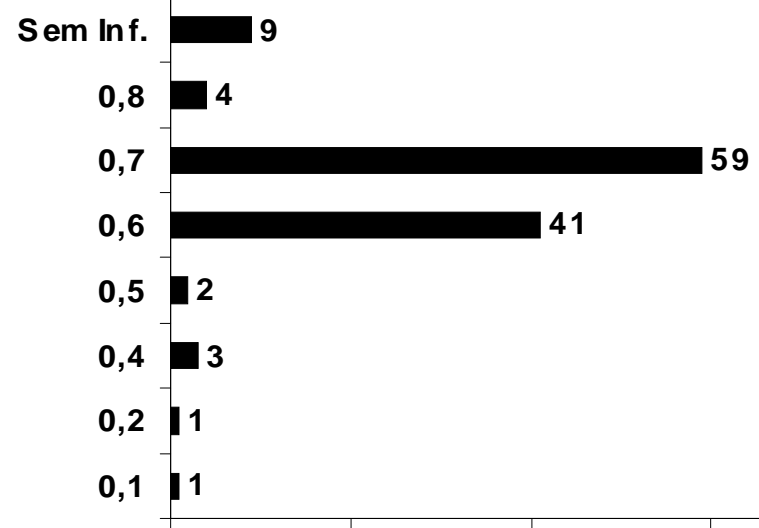

Número 
Figura 45.

TEORES DE FLÚOR (EM ppm) EM ÁGUAS COLETADAS NO

PS PERUS. SÃO PAULO, SP, 1990-1999.

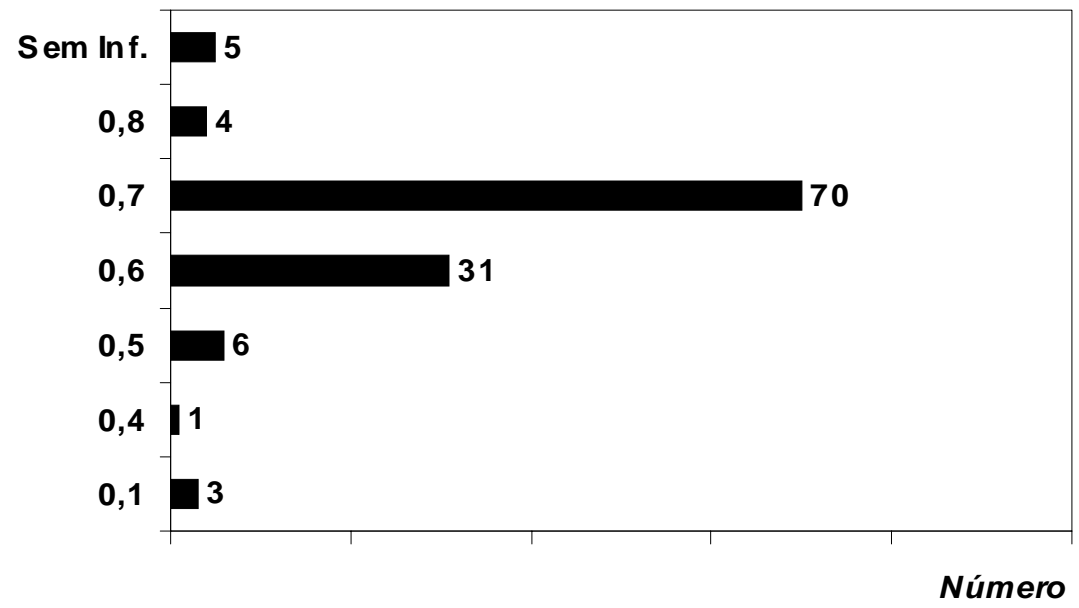

Figura 46.

TEORES DE FLÚOR (EM ppm) EM ÁGUAS COLETADAS NO PAM EĹSIO TEIXEIRA LEITE. SÃO PAULO, SP, 1990-1999.

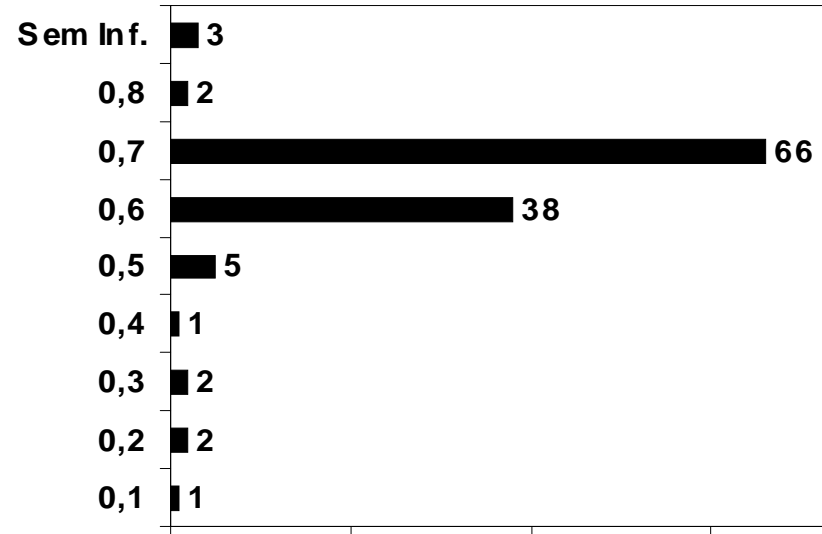

Número 
Figura 47.

TEORES DE FLÚOR (EM ppm) EM ÁGUAS COLETADAS NA UBS JARDI M IPANEMA. SÃO PAULO, SP, 1990-1999.

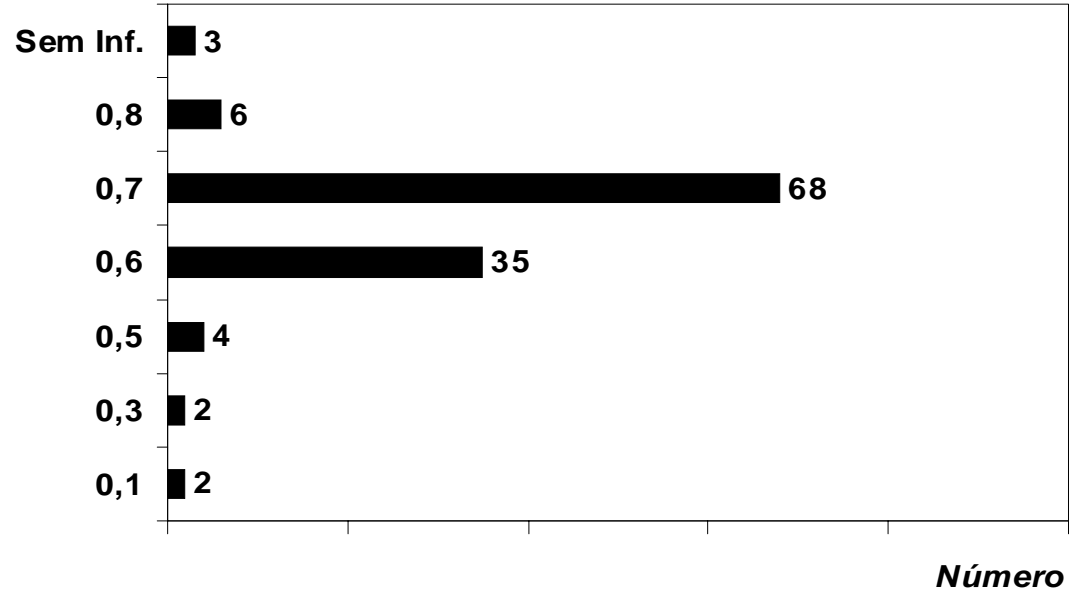

Figura 48.

TEORES DE FLÚOR (EM ppm) EM ÁGUAS COLET ADAS NO PAM VILA JAGUARA. SÃO PAULO, SP, 1990-1999.

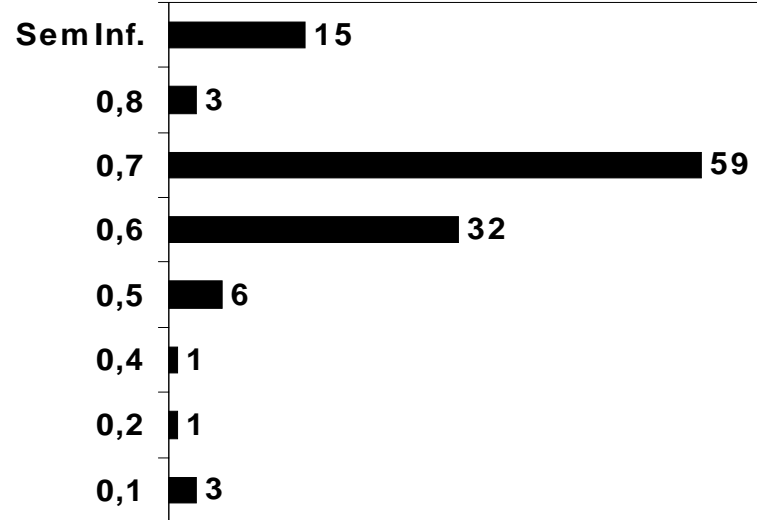

Número 
Figura 49.

TEORES DE FLÚOR (EM ppm) EM ÁGUAS COLETADAS NO PAM MOINHO VELHO. SÃO PAULO, SP, 1990-1999.

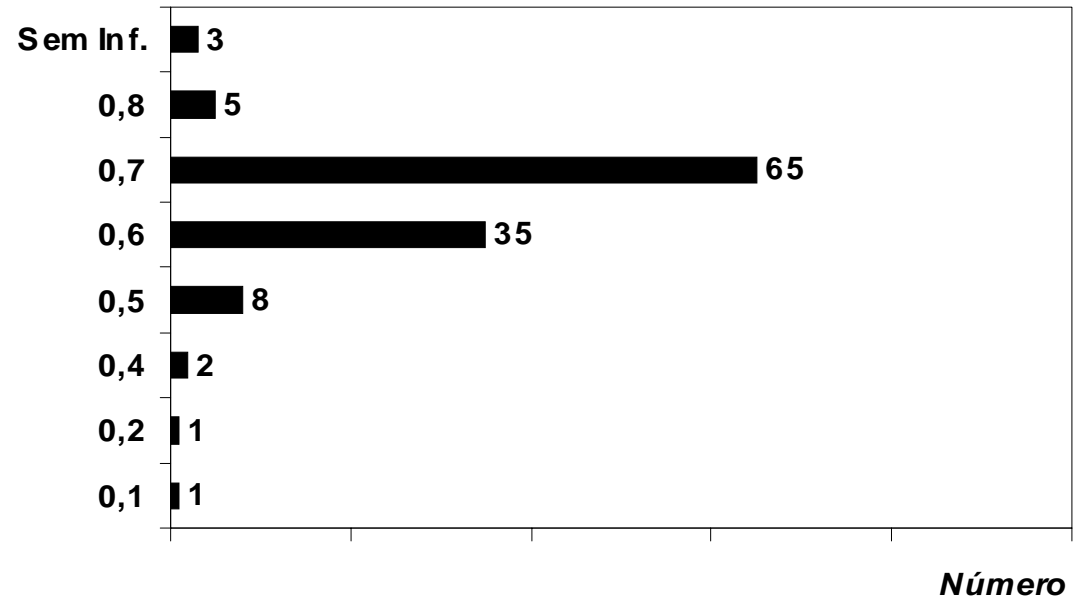

Figura 50.

TEORES DE FLÚOR (EM ppm) EM ÁGUAS COLETADAS NO PAM JARDIM CIDADE PIRITUBA. SÃO PAULO, SP, 1990-1999.

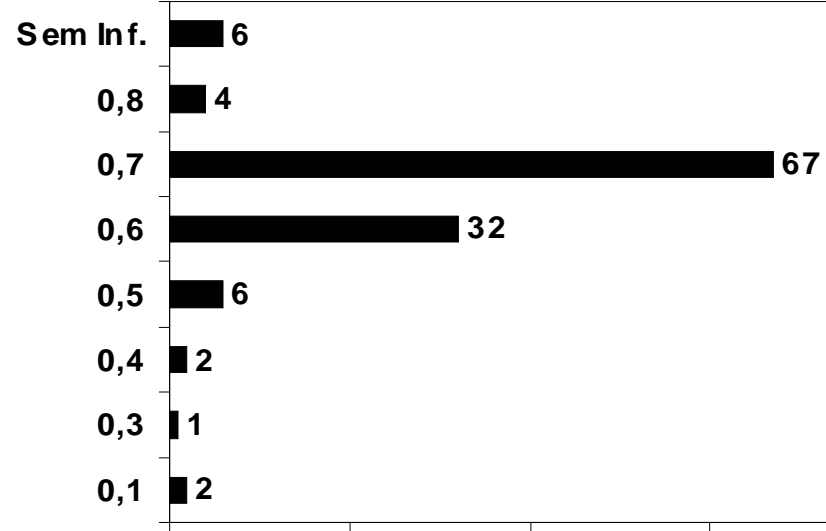

Número 
Figura 51.

TEORES DE FLÚOR (EM ppm) EM ÁGUAS COLETADAS NA UBS PARELHEIROS. SÃO PAULO, SP, 1990-1999.

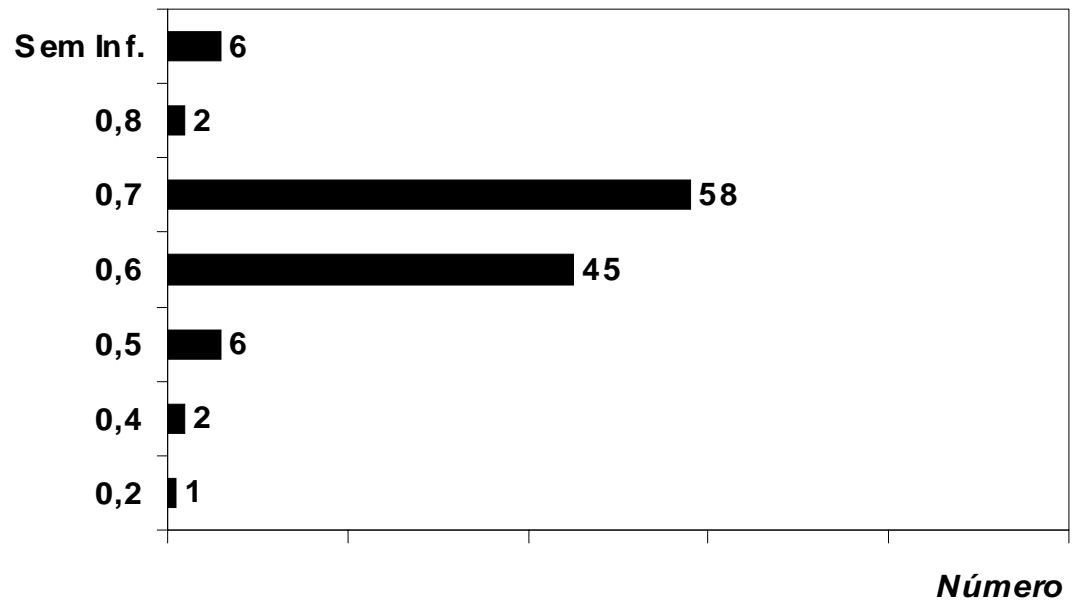

Figura 52.

TEORES DE FLÚOR (EM ppm) EM ÁGUAS COLETADAS NO PAM CHÁCARA SANTO ANTONIO. SÃO PAULO, SP, 1990-1999.

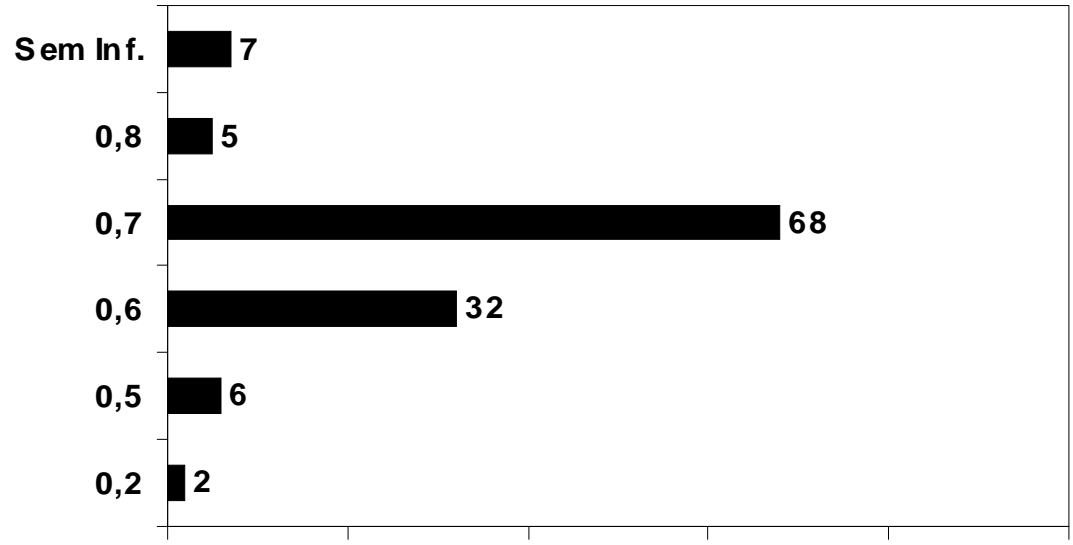

Número 
Figura 53.

TEORES DE FLÚOR (EM ppm) EM ÁGUAS COLETADAS NO PAM VILA GUACURI. SÃO PAULO, SP, 1990-1999.

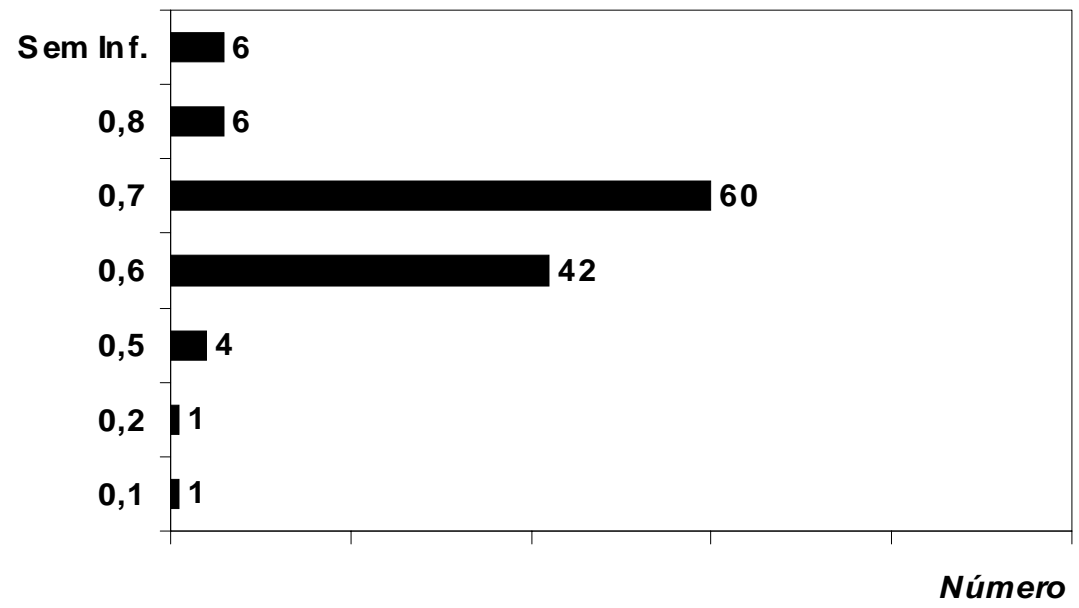

Figura 54.

TEORES DE FLÚOR (EM ppm) EM ÁGUAS COLETADAS NO PAM VELEIROS. SÃO PAULO, SP, 1990-1999.

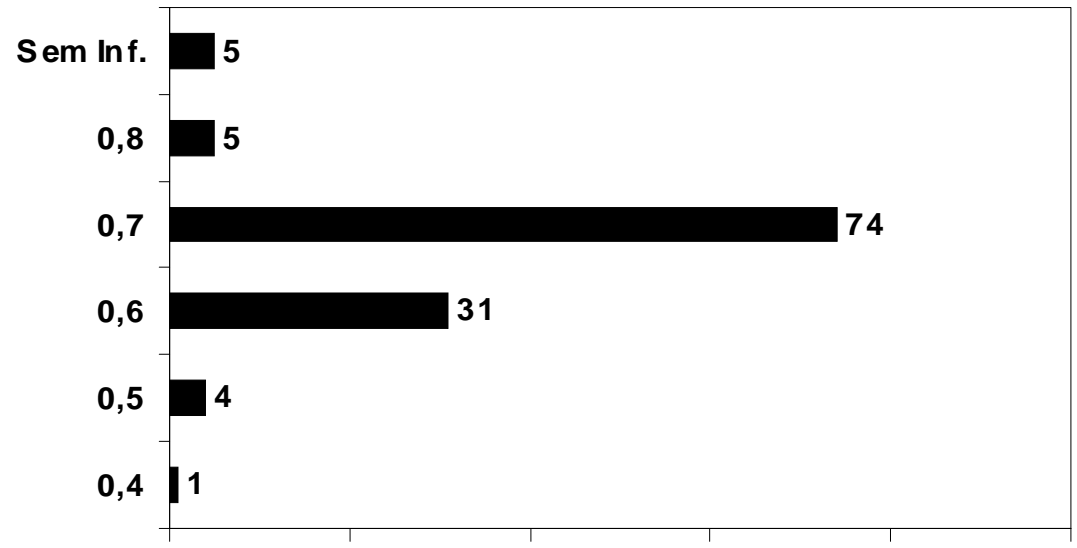

Número 
Figura 55.

TEORES DE FLÚOR (EM ppm) EM ÁGUAS COLETADAS NO PAM JARDIM ELIANA. SÃO PAULO, SP, 1990-1999.

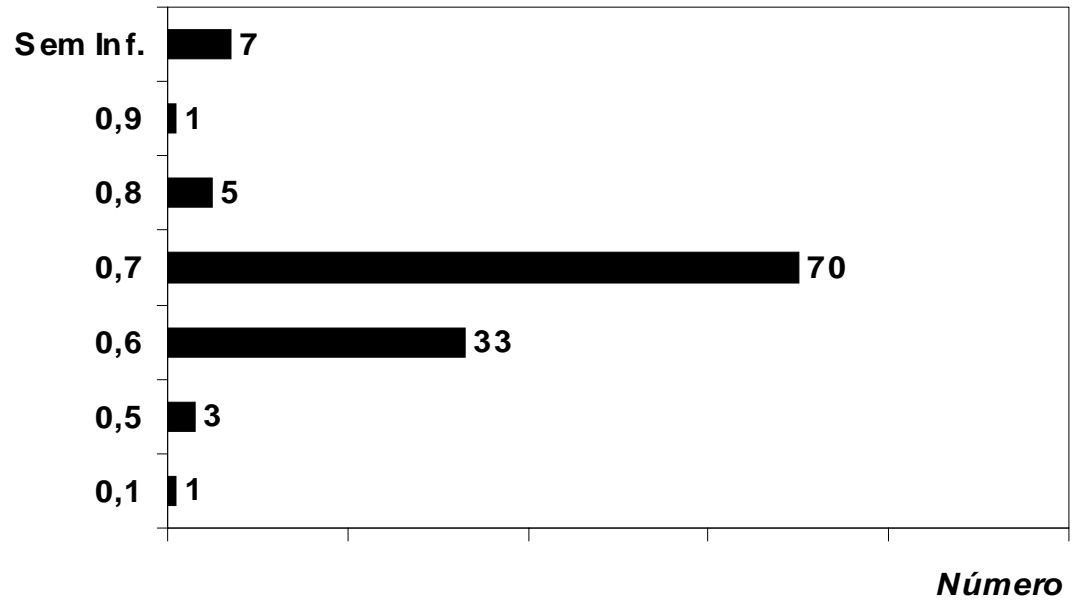

Figura 56.

TEORES DE FLÚOR (EM ppm) EM ÁGUAS COLETADAS NO PAM JARDIM MIRNA. SÃO PAULO, SP, 1990-199 9.

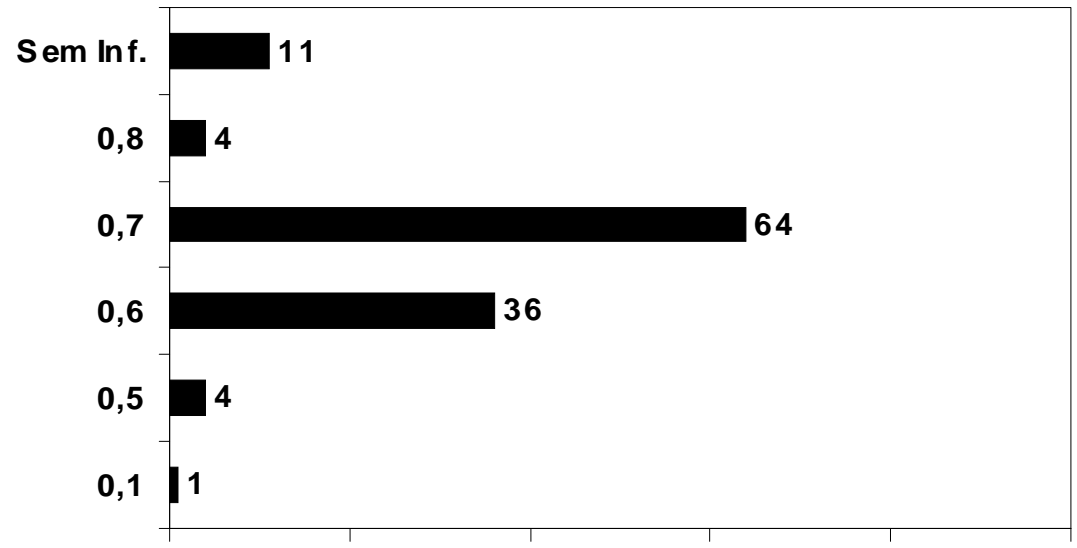

Número 
Figura 57.

TEORES DE FLÚOR (EM ppm) EM ÁGUAS COLETADAS NO

PAM JARDIM SÃO BENTO. SÃO PAULO, SP, 1990-1999.

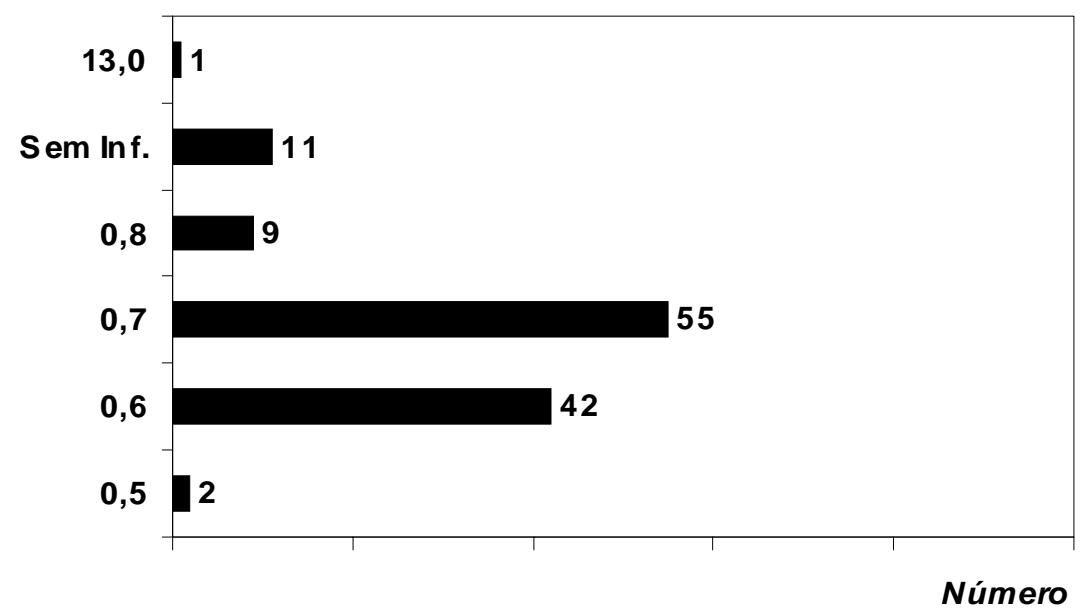

Figura 58.

TEORES DE FLÚOR (EM ppm) EM ÁGUAS COLETADAS NA UBS JARDIM MARCELO. SÃO PAULO, SP, 1990-1999.

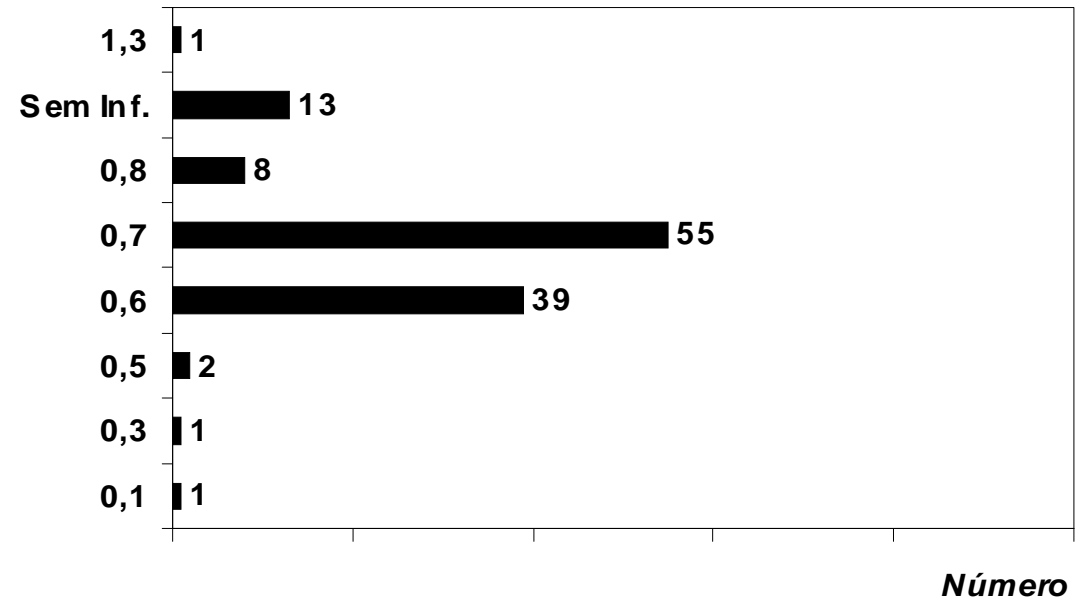


Figura 59.

TEORES DE FLÚOR (EM ppm) EM ÁGUAS COLETADAS NO

PAM CAMPO LIMPO. SÃO PAULO, SP, 1990-1999.

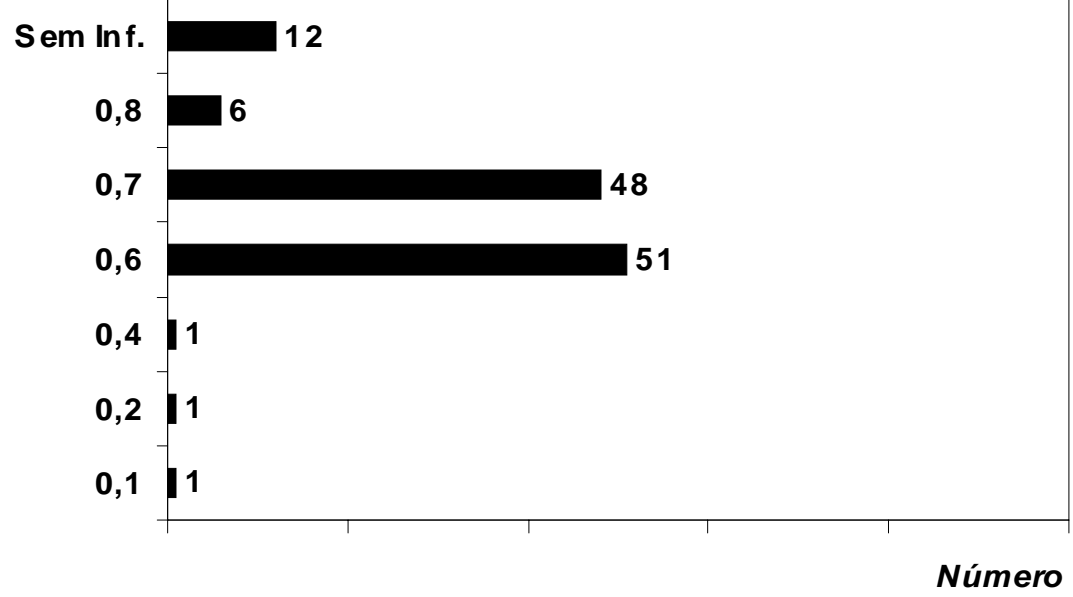

Figura 60.

TEORES DE FLÚOR (EM ppm) EM ÁGUAS COLETADAS NA UBS JARDIM ANGELA. SÃO PAULO, SP, 1990-199 9.

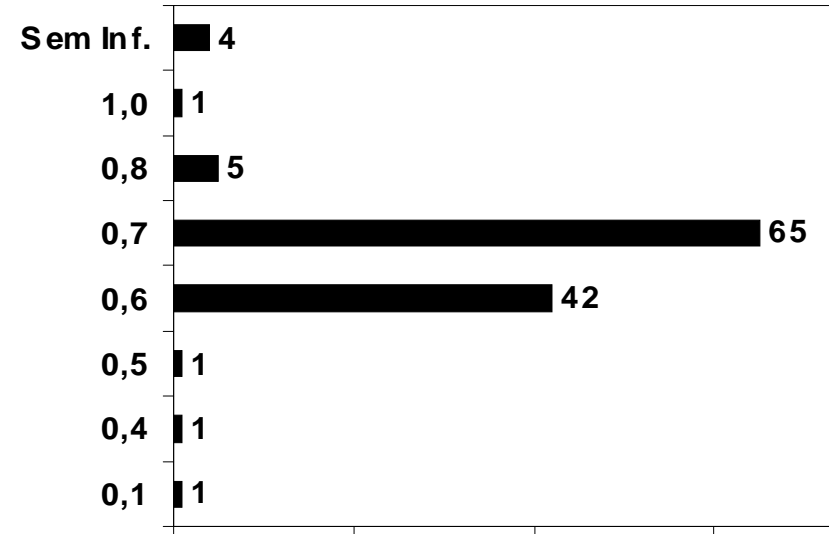

Número 
Figura 61.

TEORES DE FLÚOR (EM ppm) EM ÁGUAS COLETADAS NO

PAM JARDIM TOMÁS. SÃO PAULO, SP, 1990-1999.

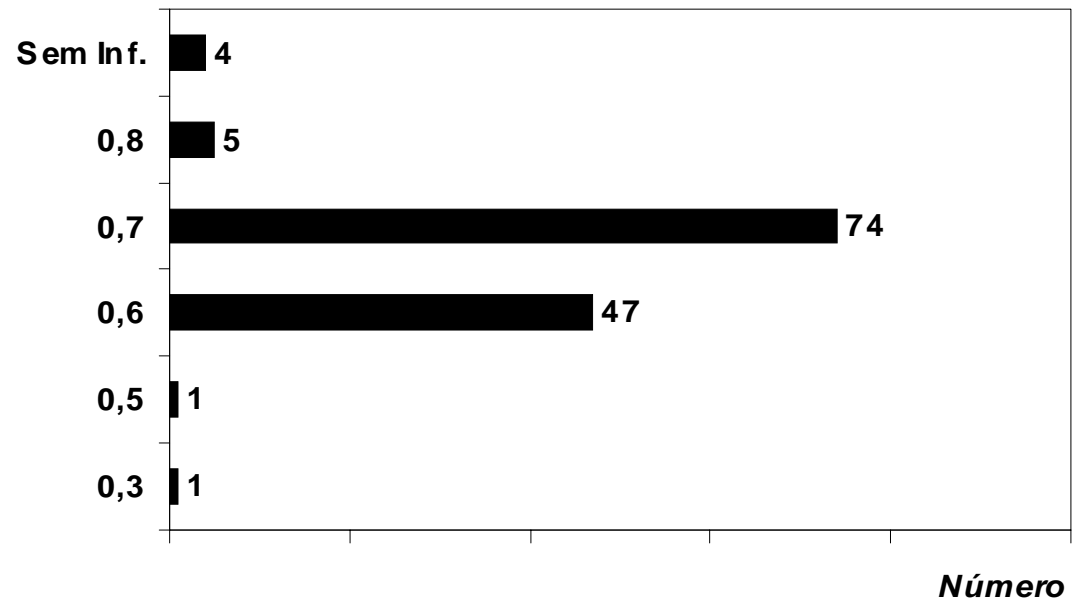

Figura 62.

TEORES DE FLÚOR (EM ppm) EM ÁGUAS COLETADAS NO

PAM JARDIM HERCULANO. SÃO PAULO, SP, 1990-1999.

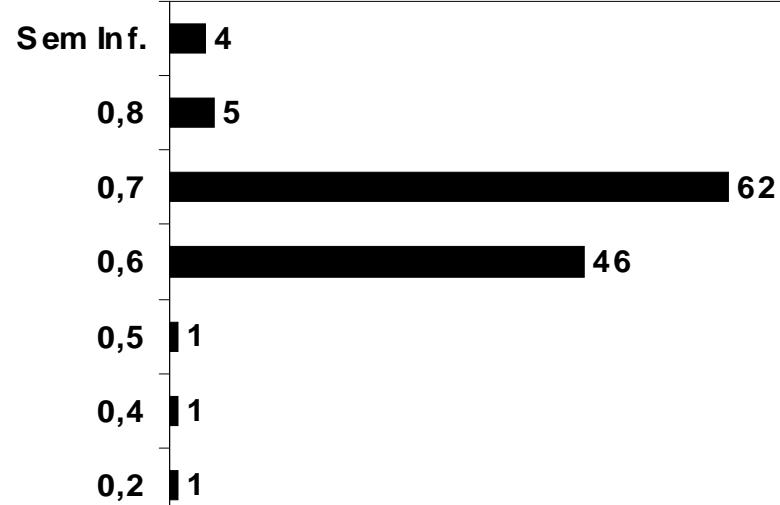

Número 
Figura 63.

TEORES DE FLÚOR (EM ppm) EM ÁGUAS COLETADAS NA UBS PARQUE ANHANGUERA. SÃO PAULO, SP, 1990-1999.

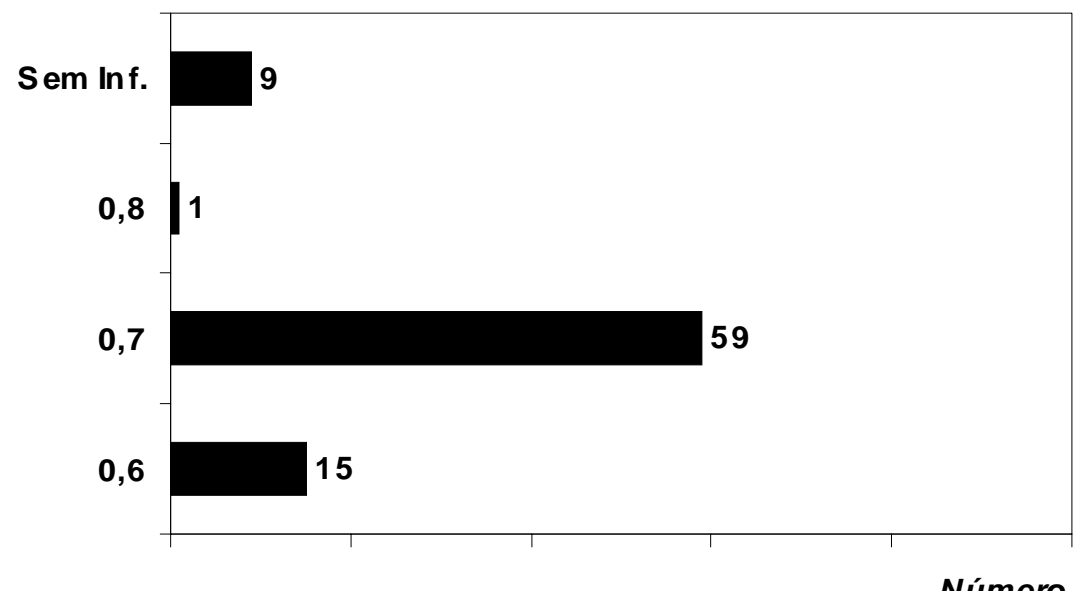

Figura 64.

TEORES DE FLÚOR (EM ppm) EM ÁGUAS COLETADAS NO PASDR. CARLOS MUNIZ. SÃO PAULO, SP, 1990-1999.

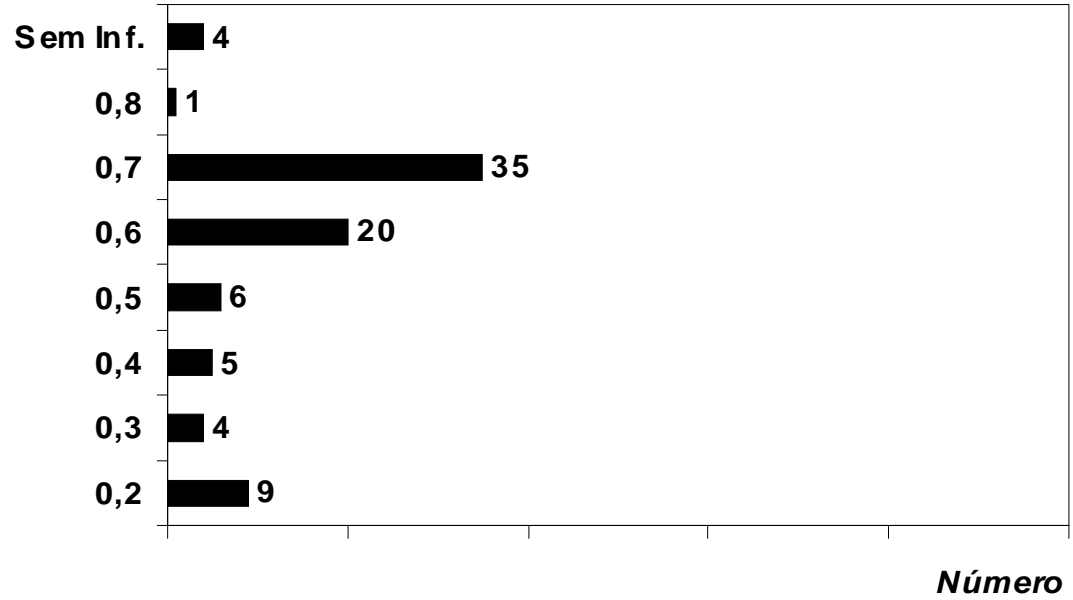


Figura 65.

TEORES DE FLÚOR (EM ppm) EM ÁGUAS COLETADAS NO PAS DR. EMILIO S. OLIVEIRA. SÃO PAULO, SP, 1990-1999.

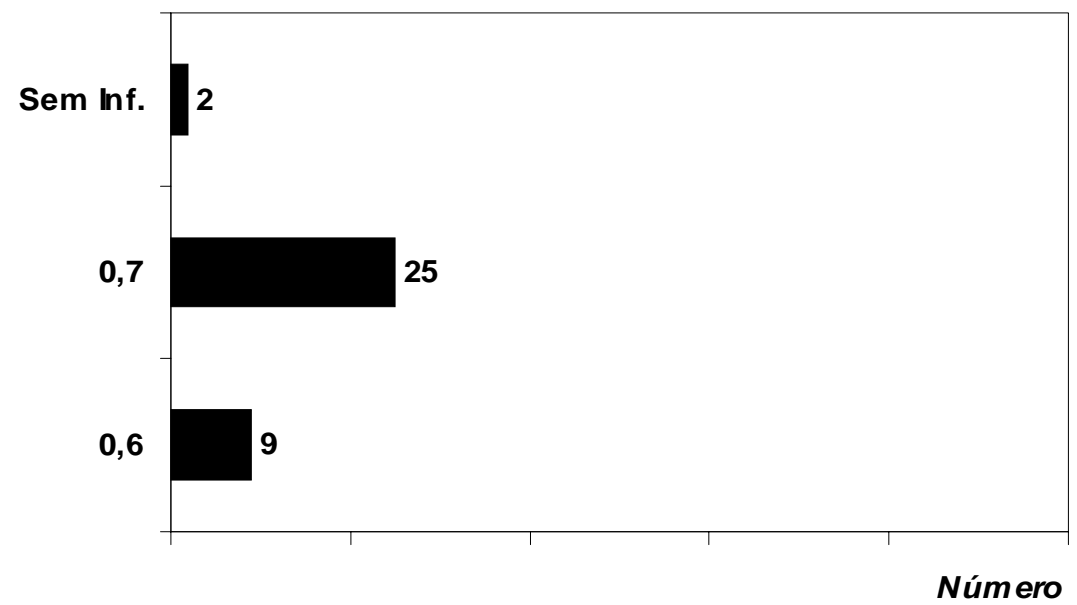

Figura 66.

TEORES DE FLÚOR (em pp m) OBTIDOS MENSALMENTE

EM ÁGUAS DA REGIÃO DO JARDIM D'ABRIL.

SÃO PAULO, SP, 1990-1999

ppm F

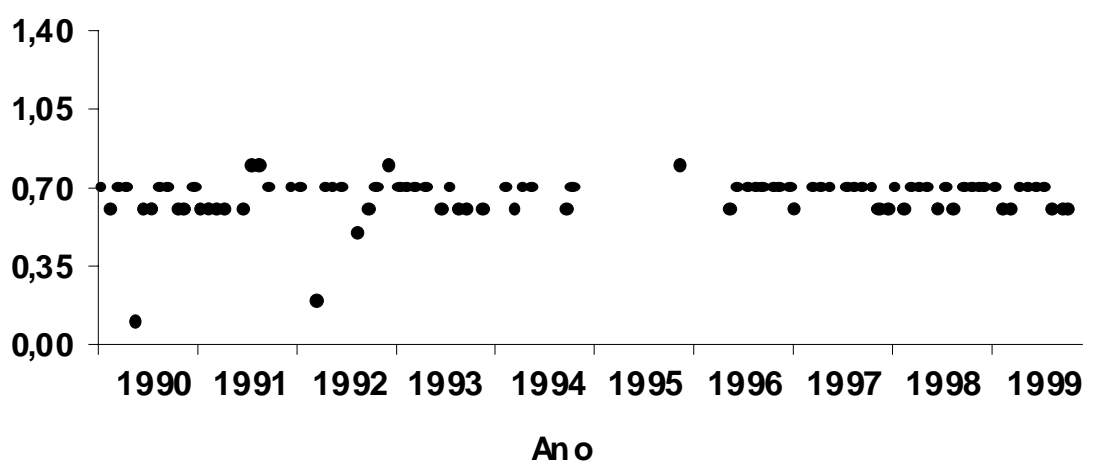


Figura 67.

TEORES DE FLÚOR (em ppm) OBTID OS MENSALMENTE EM ÁGUAS DA REGIÃO DA VILA JACUÍ.

SÃO PAULO, SP, 1990-1999

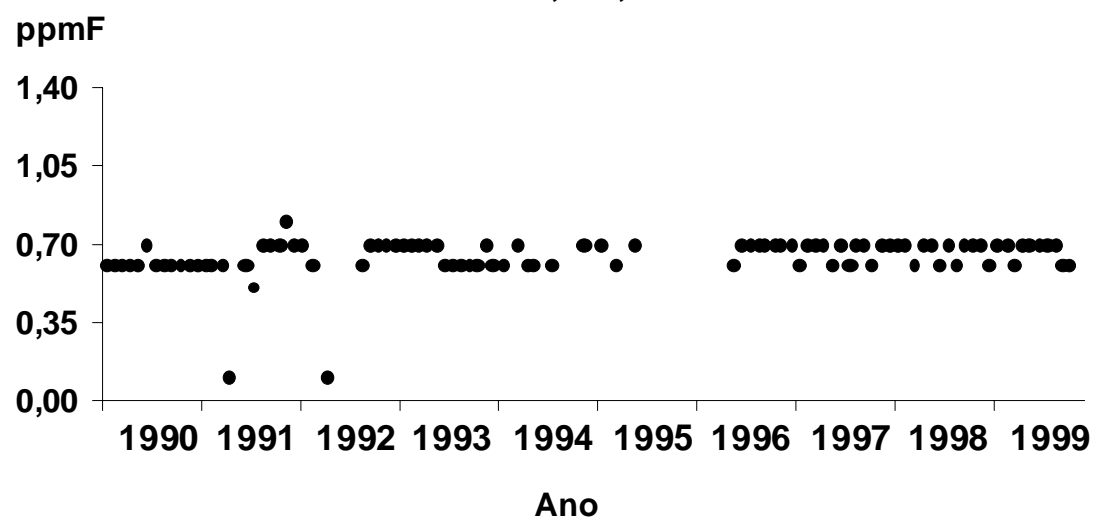

Figura 68.

TEORES DE FLÚOR (em ppm) OBTIDOS MENSALMENTE EM ÁGUAS DA REGIÃO DO JARDIM ANGELA. SÃO PAULO, SP, 1990-1999

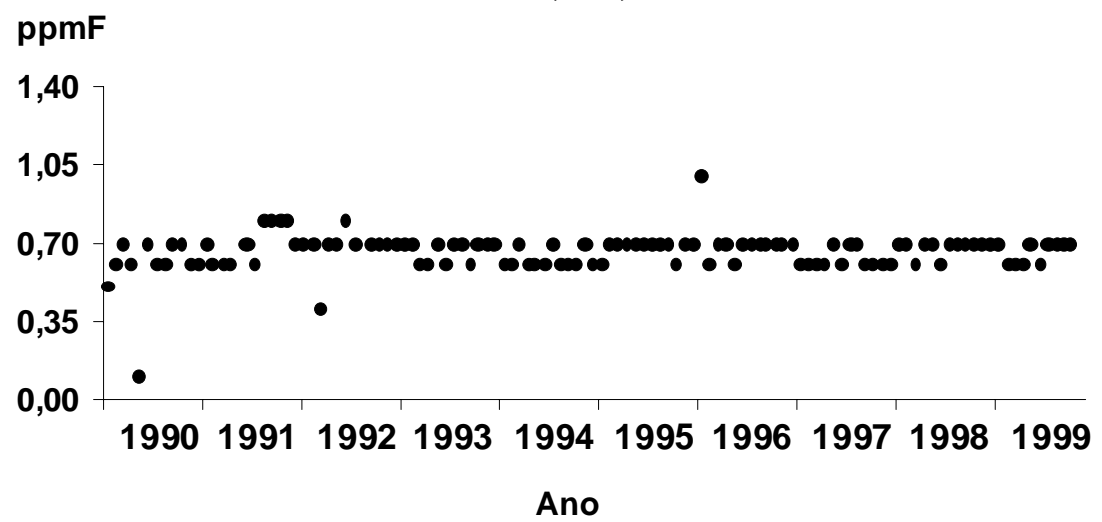


Figura 69.

TEORES DE FLÚOR (em ppm) OBTIDOS MENSALMENTE EM ÁGUAS DA REGIÃO DE PERUS.

SÃO PAULO, SP, 1990-1999

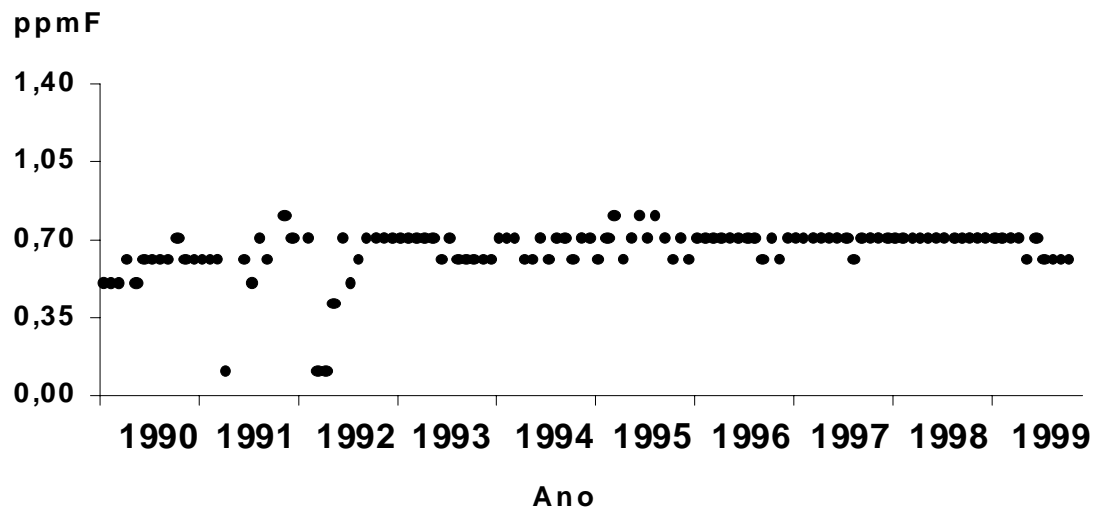

Figura 70.

TEORES DE FLÚOR (em ppm) OBTIDOS MENSALMENTE EM ÁGUAS DA REGIÃO DA FREGUESIA DO Ó.

SÃO PAULO, SP, 1990-1999

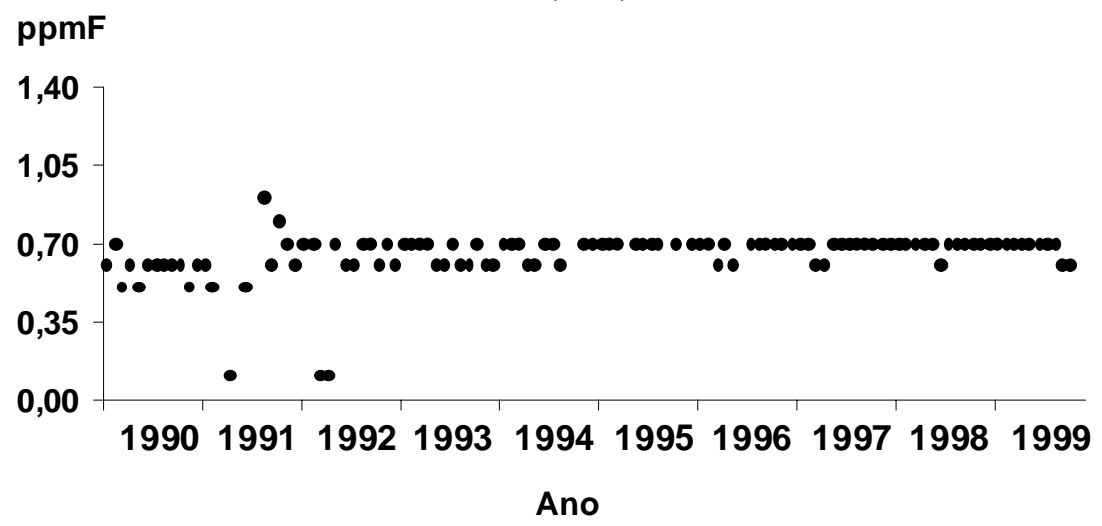


Figura 71.

TEORES DE FLÚOR (em ppm) OBTIDOS MENSALMENTE EM ÁGUAS DA REGIÃO DA BELA VISTA.

SÃO PAULO, SP, 1990-1999

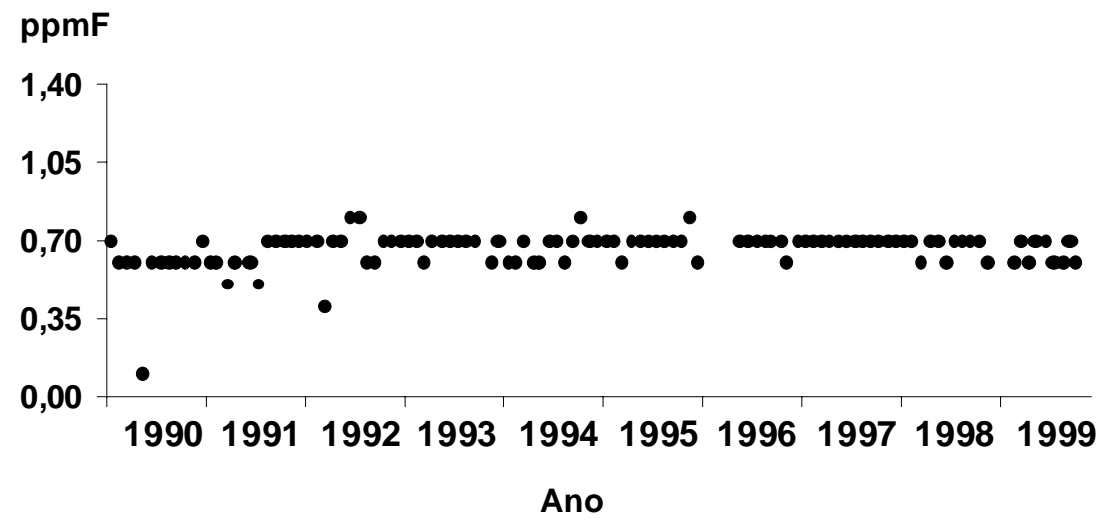




\subsection{Valores Aberrantes}

Dezenas de profissionais de saúde estão envolvidos na operacionalização do sistema de vigilância, tornando-o vulnerável. Para neutralizar ações indevidas, o sistema foi concebido de modo a que os valores de um determinado ponto pudessem ter sua validade aferida pelos resultados obtidos em pelo menos outros dois. Tal delineamento permite mútua aferição de resultados. Dessa forma, admitindo-se variabilidade insignificante nos teores em pontos próximos e com água originada na mesma ETA, valores expressivamente diferentes devem ser desconsiderados para aquele ponto. Neste caso, pode-se adotar como correto para aquele ponto os valores observados nos pontos que o controlam. Assim, detecta-se facilmente ações indevidas e manipulações impertinentes de amostras que levam à obtenção, às vezes, de valores aberrantes. Na Tabela 46 podem ser observadas algumas dessas situações.

Tabela 46. Valores aberrantes de flúor detectados em amostras de água de abastecimento público no município de São Paulo, no período 1990-1999.

\begin{tabular}{ccc}
\hline TEOR & MÊS & LOCAL \\
\hline $15,0 \mathrm{ppm}$ & $10 / 91$ & EMPG Infante Dom Henrique \\
$2,5 \mathrm{ppm}$ & $12 / 95$ & UBS Jardim D'Abril \\
$3,0 \mathrm{ppm}$ & $10 / 95$ & PAM Joaquim Eirado \\
$7,5 \mathrm{ppm}$ & $12 / 95$ & PAM Joaquim Eirado \\
$3,5 \mathrm{ppm}$ & $06 / 95$ & PAM Freguesia do Ó \\
$4,1 \mathrm{ppm}$ & $01 / 96$ & PAM Jardim Helena \\
$13,0 \mathrm{ppm}$ & $04 / 96$ & UBS Jardim São Bento \\
$2,4 \mathrm{ppm}$ & $08 / 97$ & UBS Nossa Senhora do Carmo \\
\hline
\end{tabular}




\section{DISCUSSÃO}

A grande variabilidade nos teores de flúor observada nas águas de São Paulo no início dos anos 90 comprova a relevância do heterocontrole para a manutenção de padrões adequados e para assegurar a qualidade da fluoretação.

Essa variabilidade foi também detectada por BARROS e col. (1990) ao analisar dados relativos ao teor de flúor nas águas da cidade de Porto Alegre, RS, abrangendo um período de 13 anos. Foram detectadas "descontinuidades periódicas" e a quantidade de flúor variou "de 0,39 a 3,10 ppm de flúor" (teor ótimo na cidade igual a 0,8 ppm F, no verão, e 1,0 ppm F no inverno).

Os primeiros resultados obtidos pelo sistema permitem compreender porque, na I Conferência Municipal de Saúde Bucal de São Paulo, realizada em 07/08/1993, os delegados aprovaram que houvesse "controle e fiscalização por órgão competente (...) com a publicação trimestral dos relatórios no Diário Oficial do Município, grande imprensa e outros órgãos de divulgação de fácil acesso à população, garantindo-se recursos para tanto e sob supervisão da SMS." (SÃO PAULO 1993).

Tal recomendação encontrou eco na Câmara Municipal de São Paulo: em 1994 foi aprovada a Lei oㅜ 11.488, de 11/03/1994, determinando que a Prefeitura deveria manter "programa permanente de vigilância sanitária visando a medição e controle dos níveis de flúor existente nas águas destinadas ao abastecimento da rede pública." 
Os resultados obtidos no município com o controle da fluoretação vêm exercendo importante influência, tanto no âmbito estadual, quanto em outras regiões. Em São Paulo, a Secretaria de Estado da Saúde aprovou, em 1995, a Resolução SS-250, de 15/08/1995, estabelecendo que "o teor de concentração ideal do íon fluoreto na água destinada ao consumo humano é 0,7 mg/l' e que serão considerados "dentro do padrão de potabilidade" as águas que apresentarem de 0,6 a 0,8 mg F/l. No artigo 2o da mencionada Resolução afirma-se, entretanto, que serão consideradas fora do padrão de potabilidade as águas que "apresentarem teores de íon fluoreto inferiores a 0,6 mg/l e superiores a $1,0 \mathrm{mg} / \mathrm{l}$ '.

Sistemas de vigilância, baseados no heterocontrole, foram montados e vêm sendo mantidos em diferentes lugares, destacando-se entre outros Santos (MANFREDINI 1993), Curitiba (DANTAS 1996), Fortaleza (LUZ e col. 1998), Salvador (SILVA e CARDOSO 1998) e em diversos municípios do Rio Grande do Sul, incluindo Porto Alegre (RIO GRANDE DO SUL 1999), e do Estado de São Paulo (CALVO 1996).

Tal esforço, para implantar sistemas de vigilância da fluoretação em diferentes municípios, foi estimulado pelos participantes do VIII ENATESPO (Encontro Nacional de Administradores e Técnicos do Serviço Público Odontológico), realizado em São Paulo de 21 a 25 de outubro de 1991. No documento final daquele evento consta, significativamente:

"Não renunciar à luta pelo provimento de água de abastecimento público de boa qualidade, clorada e fluoretada para todos os brasileiros. Desenvolver sistemas de vigilância sanitária sobre a fluoretação de 
águas de abastecimento público, em todos os municípios, requisito este imprescindível na defesa da fluoretação e da saúde bucal coletiva. E que se cumpra a Lei 6050/74."

Na II Conferência Estadual de Saúde Bucal (São Paulo, 27-29/8/1993) foi aprovada a necessidade de:

"haver controle e vigilância por órgão competente distinto da empresa responsável pela fluoretação (heterocontrole); devendo a instância responsável pelo heterocontrole tornar público, através dos meios de comunicação, boletins periódicos com os resultados obtidos. Nesse sentido (...) expressam o apoio irrestrito à luta dos cidadãos brasileiros para a conquista e garantia do acesso à água tratada de boa qualidade, clorada e fluoretada."

Em pesquisa conduzida pela Companhia Estadual de Tecnologia e Saneamento Básico (CETESB), sobre concentração de flúor na água de abastecimento público de 22 cidades do Estado de São Paulo, constatou-se que $14(63,64 \%)$ apresentavam os valores abaixo do teor ótimo recomendado. (CETESB apud VASCONCELLOS 1982).

Num estudo transversal realizado em 1995 em 25 municípios do Estado de São Paulo, com o objetivo de verificar os teores de flúor nas águas, foram colhidas, em cada localidade, amostras de água em 3 pontos do território. Em 11 municípios o teor de flúor na água estava abaixo de 0,6 ppm. Em 10 o teor foi considerado adequado e em 4 municípios estava acima de 0,8 ppm (CHAIM e col. 1995). 
Analisando a quantidade de flúor em águas colhidas em 60 pontos da cidade do Rio de Janeiro, MODESTO e col. (1999) observaram, em estudo transversal, que todas as amostras continham menos de 0,7 ppm, teor considerado ótimo para o local. Apenas 3 (5\%) das 60 amostras apresentaram teor de flúor superior a 0,5 ppm. A média foi 0,22 ppm, quantidade sem significado para a prevenção da cárie dentária.

Tais estudos evidenciam situações similares às observadas nos primeiros anos do sistema na capital paulista, reiterando a importância da sua existência. Aliás cabe ressaltar, quanto a isso, que o sistema paulistano iniciou operações justamente quando havia tendência de perda de qualidade da fluoretação (MANFREDINI 1991), o que fica evidente com o declínio de locais adequados: de 73,3\% em 1990 para $56,7 \%$ em 1992. O sistema detectou este fato e as providências foram tomadas, contribuindo para melhorar a qualidade da fluoretação.

Nas Figuras 66 a 71, apresenta-se graficamente a evolução dos valores observados nas amostras, mensalmente, no período 1990-1999, respectivamente nas regiões do Jardim d'Abril, Vila Jacuí, Jardim Angela, Perus, Freguesia do Ó e Bela Vista. Embora sejam áreas geográficas selecionadas de diferentes regiões do município de São Paulo apresentadas apenas para ilustrar a dinâmica da fluoretação, sem qualquer pretensão de representatividade do município como um todo - , percebe-se nitidamente os problemas detectados na fluoretação das águas nos primeiros anos de operações do sistema de vigilância, e a tendência de estabilização das 
amostras em torno dos valores aceitáveis e do teor ótimo $(0,7 \mathrm{ppm})$, a partir de 1994.

Os problemas detectados no ano de 1990 (Tabela 14) foram detectados pelo sistema de vigilância e a Secretaria Municipal de Saúde de São Paulo comunicou a SABESP. Entretanto, as deficiências na fluoretação persistiram em 1991 (Tabela 15) e nos primeiros meses de 1992 (Tabela 16). Como os problemas não se resolviam, o fato gerou atritos entre a Prefeitura de São Paulo e a SABESP, empresa concessionária do serviço de abastecimento público de água na Capital paulista, chegando à imprensa. Em matéria intitulada "Água vai continuar sem flúor, admite Sabesp", com o subtítulo " $A$ curto prazo, a empresa não tem como fluoretar a água que distribui para 20 milhões de pessoas, por falta do produto no mercado", o jornal O Estado de S.Paulo publicou em 4/09/1992:

"A Companhia de Saneamento Básico do Estado de São Paulo (Sabesp) admite não ter meios a curto prazo de cumprir as leis federal e estadual que mandam que a água distribuída à população tenha flúor para prevenir cáries. (...) O ácido fluorsilícico [composto utilizado em São Paulo para fluoretar a água] é um subproduto da fabricação de fertilizantes. Como houve uma redução na produção de fertilizantes, diminuiu também a do ácido, informou [a assessoria de imprensa da Sabesp]. (...) Não foi possível também importar o produto dos Estados Unidos. Para o transporte são necessários navios especiais e as compras devem ser regulares. (...) Há outro empecilho: 'Há o problema de tancagem, pois, além de o aluguel ser muito caro, são raros os locais 
para armazenar adequadamente o produto.' (...) De dezembro a maio, entressafra agrícola, há ainda uma redução de $50 \%$ na produção de fertilizantes, o que acaba prejudicando a fabricação do ácido. Por isso, o fornecimento à Sabesp tem sido irregular, com os fornecedores entregando um terço da quantidade pedida. Segundo a própria Sabesp, os 20 milhões de pessoas de 300 municípios paulistas abastecidos pela empresa estão recebendo água com doses de flúor que variam de 0,2 a 0,5 miligrama por litro - a quantidade legal é de 0,7 miligrama. 'Nas quantidades menores que 0,5 miligrama por litro a ação do flúor é praticamente nula', informa o professor Roberto Augusto Castellanos, da Faculdade de Saúde Pública da USP. (...) ‘O mais grave é que a Sabesp vem negligenciando há pelo menos dois anos e meio o abastecimento de água com flúor na cidade de São Paulo', acusou o dentista Douglas Schneider, do Departamento [sic] de Saúde Bucal da Secretaria Municipal de Saúde. (...) Este ano, a situação se agravou: a subdosagem [sic] de flúor vem ocorrendo desde março, quando os técnicos da Secretaria da Saúde detectaram que 82,3\% das amostras estavam abaixo do recomendado, oscilando entre 0,5 e $0,1 \mathrm{mg}$ de flúor por litro de água. A situação pior é nos bairros de Santana, Tucuruvi, Freguesia do Ó e Brasilândia. O bairro do Butantã é o melhor, onde o índice [sic] de fluoretação oscila entre 0,8 e 0,6 mg. 'A Sabesp acha um absurdo essa acusação, porque a empresa não tem o menor controle sobre a produção de fertilizantes', disse [a assessoria de imprensa da 
Sabesp], ao comentar a acusação do Departamento de Saúde Bucal do município." (OESP 1992)

A montagem de sistemas de heterocontrole podem contribuir, efetivamente, para melhorar a qualidade da fluoretação. MANFREDINI (1995) refere que no Município de Santos, após ter sido obtido, num primeiro momento (maio a julho de 1990), 60,9\% de amostras aceitáveis, a porcentagem aumentou para $68,1 \%$ de amostras aceitáveis em 1991, e 94,4\% em 1992.

Entretanto, no município de São Paulo, apesar do êxito e eficácia do sistema de vigilância nos primeiros anos de operações, a qualidade do próprio sistema foi comprometida no período de 1993 a 1996, com o aumento do número de locais sem informação: a porcentagem de locais nessa condição elevou-se de 11,3\% em 1993 para 43,5\% em 1996 (Figura 2), quase chegando ao ponto de comprometer irremediavelmente o sistema, com a iminente perda da série histórica para vários dos 63 pontos que o constituem.

Em relação à perda de informação ("sem informação") para as amostras, o mês crítico foi maio. No período 1990-1999, não foram coletadas, no mês de maio, 139 (22,53\%) das 617 possíveis amostras (Tabela 28). O segundo pior mês, quanto à perda de possíveis amostras foi dezembro, com 120 perdas, correspondendo a 19,45\% (Tabela 35).

O ano crítico foi 1993, com a perda de $202(27,16 \%)$ das 744 amostras que poderiam ter sido coletadas naquele ano (Tabela 17). O segundo pior ano, 
neste aspecto, foi 1996, com a perda de $174(23,40 \%)$ das 744 possíveis amostras (Tabela 20).

Este fato coincide cronologicamente com a decisão política de privatizar a gestão da saúde no município, com a implantação do denominado Plano de Atendimento à Saúde - PAS (SÁ e col. 1997; COHN e ELIAS, 1999).

A implantação do PAS desestruturou a rede de unidades básicas de saúde no município (SÁ e col. 1997), justamente a base operacional do sistema de vigilância da fluoretação.

Os dados indicam significativas descontinuidades na coleta de amostras em muitos locais a partir de 1993. Os números (Tabelas 21, 22 e 23) sugerem também que houve retomada e valorização do sistema de heterocontrole a partir de 1997. Mesmo assim, as descontinuidades prosseguiram em alguns locais sendo que, na unidade de saúde Ponte Rasa, nenhuma amostra foi colhida no período 1996-1999. A Figura 35 expressa gráfica e numericamente o significado dessas perdas para o conjunto das informações relativas aquele local, no período 1990-1999.

Apesar da recuperação do sistema de vigilância a partir de 1997, tais fatos contribuíram para comprometer sua credibilidade.

Mesmo que os dados indiquem que o sistema de vigilância está controlando a fluoretação (apenas 3,2\% dos locais sem informação no período 1997-1999) (Figura 2), é inegável que o mau desempenho no período 19931996 projeta efeitos para o período posterior (1997-1999), uma vez que não há menção, nos relatórios, de qualquer fato explicativo do mau desempenho. 
Aliás, não há explicações nem para a deterioração do sistema nem para a súbita melhora do seu desempenho.

Os relatórios não têm informado, também, sobre como tem sido feito (admitindo-se que vem sendo feito) o controle das medidas (erros intraexaminadores e interexaminadores). Tendo havido perda de credibilidade, é lícito admitir que a partir de 1995 - quando não se obteve informações para cerca de um terço dos locais - até 1999, o sistema pode não ter sido capaz de detectar eventuais problemas com a fluoretação das águas no município de São Paulo. 


\section{CONSIDERAÇÕES FINAIS}

O fato de as amostras aceitáveis terem sido em porcentagens sempre iguais ou superiores a $80 \%$ é altamente sugestivo de que a população do município de São Paulo esteve efetivamente exposta à ação preventiva do flúor, no período 1990-1999. Em 93\% das amostras examinadas o teor esteve em níveis considerados ótimos. Informações sobre a epidemiologia da cárie dentária entre escolares paulistanos também indicam exposição ao flúor. Observa-se, entretanto, que a porcentagem de locais adequados variou entre $56 \%$ a $96 \%$ e que, no período entre 1993 e 1996, a porcentagem de locais para os quais não se obteve informações aumentou de $11 \%$ para $43 \%$. Podese então concluir que embora seja admissível que, no período 1990-1999, a população tenha sido exposta a níveis adequados de flúor nas águas de abastecimento público, a elevada porcentagem de locais sem informação entre 1993 e 1996 e a ausência de explicações para as alterações relevantes no desempenho do sistema de vigilância, tanto para pior quanto para melhor, ameaçam-Ihe a credibilidade para atestar, de modo cabal, o benefício da fluoretação.

Outro aspecto a considerar é a conveniência de se fixar, através de norma legal, a obrigatoriedade de a empresa de saneamento encaminhar, mensalmente, um relatório das medidas diárias de controle operacional da fluoretação naquele mês, ao órgão municipal incumbido da vigilância sanitária. Tais medidas deveriam incluir, além do valor relativo ao teor médio diário de flúor na água, também os valores mínimo e máximo detectados diariamente em cada ETA. Desta forma, dispondo também dessas informações, relativas 
ao controle operacional, e combinando-as com as obtidas através do sistema de heterocontrole, seria possível melhorar a qualidade do controle da fluoretação das águas e fazer com que o Estado, através do Poder Público Municipal, exerça efetivamente as competências que, nesta área, atribuem-lhe tanto o texto constitucional quanto a lei orgânica da saúde. 


\section{REFERÊNCIAS BIBLIOGRÁFICAS}

1. Amaral FP. A falácia da eficiência do flúor no combate às cáries. Pau Brasil 1985; 1 (6): 79-85.

2. Amaral FP. Por que 'enriquecer' a água com flúor? In: Discriminação e mistificação em alimentos. São Paulo: Alfa-Omega; 1986.

3. [Anvisa] Agência Nacional de Vigilância Sanitária. História da vigilância sanitária no Brasil. Disponível no URL: <http://www.anvisa.gov.br/inst/historia.htm>. Capturado em 11 jan. 2001.

4. Araujo TL. Dosagem do flúor nas águas de abastecimento de São Paulo. Revista da Faculdade de Medicina Veterinária 1942; 2: 19-21.

5. Austrália. National Health and Medical Research Council. The effectiveness of water fluoridation. Canberra: Australian Government Publishing Service; 1991.

6. Barros ERC, Scapini C, Tovo MF. Resultados da fluoretação da água em localidade que sofreu descontinuidades de dosagens. RGO 1993; 41 (5): 303-8.

7. Barros ERC, Tovo MF, Scapini C. Análise crítica da fluoretação de águas. RGO 1990; 38 (4): 247-54.

8. Bastos JRM, Lopes ES, Freitas SFT. Panorama mundial após 50 anos de uso do flúor. RGO 1993; 41 (5): 309-11.

9. Brasil. Coleção das Leis de 1974: Lei Federal no 6.050, de 24/05/1974. Brasília: Departamento de Imprensa Nacional; 1974. [Vol. III: p.107. Atos do Poder Legislativo. Leis de Abril a Junho]. 
10. Brasil. Coleção das Leis de 1975: Decreto no 76.872, de 22/12/1975.

Brasília: Departamento de Imprensa Nacional; 1976. [Vol. VIII: p.687-8. Atos do Poder Executivo. Decretos de Outubro a Dezembro].

11. Brasil. Congresso Nacional. Lei Federal no 8.080, de 19/09/1990. Diário Oficial da União 20 set. 1990, p.18055.

12. Brasil. Congresso Nacional. Lei Federal nำ 8.142, de 28/12/1990. Diário Oficial da União 31 dez. 1990, p.25694.

13. Brasil. Congresso Nacional. Lei Federal n 9.782, de 26/01/1999. Diário Oficial da União 11 fev. 1999, p.1-6.

14. Brasil. Constituição da República. Brasília: Senado Federal; 1988.

15. Brasil. Ministério da Saúde. Conselho Nacional de Saúde. Resolução no 142, de 17/11/1994. Diário Oficial da União 28 nov. 1994, p.17994.

16. Brasil. Ministério da Saúde. Gabinete do Ministro. Portaria nº 36, de 19/01/1990. Diário Oficial da União 23 jan. 1990, p.16514.

17. Buendia OC. Situação atual da fluoretação de águas de abastecimento público no Estado de São Paulo. Revista de Saúde Pública 1983; 17: 22632.

18. Burt B. Cost-effectiveness of caries prevention in dental public health. Journal of Public Health Dentistry 1989; 49: 250-344.

19. Calvo MCM. Situação da fluoretação de águas de abastecimento público no Estado de São Paulo - Brasil. São Paulo; 1996. [Dissertação de Mestrado - Faculdade de Saúde Pública, Universidade de São Paulo]. 
20. Campos MAP. Águas de abastecimento da cidade de São Paulo e seu teor de flúor. Anais da Faculdade de Farmácia e Odontologia da Universidade de São Paulo 1948/1949; 7: 209-27.

21. Capella LF, Carcereri, DL, Paiva SM e col. Ocorrência de fluorose dentária endêmica. RGO 1989; 37(5): 371-5.

22. [CDC] Centers for Disease Control and Prevention. Achievements in public health, 1900-1999: Fluoridation of drinking water to prevent dental caries. Morbidity and Mortality Weekly Reports 1999; 48 (41): 933-40.

23. $[C D C]$ Centers for Disease Control and Prevention. Engineering and administrative recommendations for water fluoridation, 1995. Morbidity and Mortality Weekly Reports 1995; 44 (RR-13): 1-40.

24. Chaib AS. Flúor, o grande engodo. Shoping News 12 mar. 1987; p.82.

25. Chaim LAF. Acadêmicos de Araras constatam irregularidades nas águas de abastecimento público. APCD Jornal 1995; dez., p.16.

26. Chaves MM, Frankel JM, Mello C. Fluoração de águas de abastecimento público para prevenção parcial da cárie dentária. Revista da APCD 1953; 7 (2): 27-33.

27. Chedid SJ. Avaliação da quantidade de dentifrício fluoretado ou $\mathrm{NaF}$ a 0,02\% no desenvolvimento de cárie em dentes decíduos - estudo in vitro utilizando modelo de ciclagens de pH. São Paulo; 1999. [Tese de Doutorado - Faculdade de Odontologia, Universidade de São Paulo]. 28. Cohn A, Elias PEM (org.). O público e o privado na saúde: o PAS em São Paulo. São Paulo: Cortez-CEDEC; 1999. 
29. Cohn A, Elias PEM, Jacobi P. Participação popular e gestão de serviços de saúde: um olhar sobre a experiência do município de São Paulo. Saúde em Debate 1993; 38: 90-3.

30. Conferência Municipal de Saúde Bucal de São Paulo, 1a . São Paulo, 1993. Relatório Final. Diário Oficial do Município de São Paulo 14 set. 1993; 38 (172): 21-2.

31. Conferência Nacional de Saúde Bucal, 1ạ. Brasília, 1986. Relatório Final. Brasília: UnB; 1986.

32. Costa EA. Vigilância sanitária: proteção e defesa da saúde. São Paulo: Hucitec-Sobravime; 1999

33. [CROSP] Conselho Regional de Odontologia de São Paulo. Fluoretação das águas da Região Metropolitana. CROSP Informativo mar 1985; 10 (23): 1 e 13.

34. Cury JA. Fluoretação da água: benefícios, riscos e sugestões. Revista Odontológica do Brasil Central 1992; 2 (5): 32-3.

35. [Dae] Água com flúor chega a 13 milhões de pessoas. Revista DAE 1985; 45 (143): 329-30.

36. Dantas NL, Domingues JEG. Sistema de vigilância dos teores de flúor na água de abastecimento público de Curitiba. Divulgação em Saúde para Debate 1996; 13: 70-82.

37. Dotta RH. Programas Sanebase e Pró-Limp: atuação da Secretaria de Obras e do Meio Ambiente no saneamento básico. Revista DAE 1985; 45 (142): 275-81. 
38. Eduardo MBP, Miranda ICS. Vigilância sanitária. São Paulo: IDS; 1998.

39. [Enatespo] Encontro Nacional de Administradores e Técnicos do Serviço Público Odontológico, 8o. São Paulo, 1991. Documento final. São Paulo: SMS/SP-SES/SP; 1991.

40. Ferreira HCG, Gomes AMM, Silva KRCS, Rodrigues CRMD, Gomes AA. Avaliação do teor de flúor na água de abastecimento público do Município de Vitória-ES. Revista da APCD 1999; 53 (6): 455-9.

41. Forni TIB. Caracterização de levantamentos epidemiológicos de fluorose dentária no Estado de São Paulo. São Paulo; 2000 [Dissertação de Mestrado - Faculdade de Saúde Pública, Universidade de São Paulo].

42. [FSP] Folha de S.Paulo. 'Exilados do PAS' querem recompensas. Folha de S. Paulo 10 dez. 2000a; 80 (26184): C6 [caderno Cotidiano].

43. [FSP] Folha de S.Paulo. Rumo ao caos. Folha de S. Paulo 6 dez. 2000b; 80 (26180): A2 [editorial].

44. Gallagan DJ, Vermillion JR. Determining optimum fluorides concentrations. Public Health Reports 1957; 72 (6): 491-3.

45. Gandra YR. Contribuição para o conhecimento do teor de flúor de água do Estado de São Paulo — significação sanitária do problema. Arquivos da Faculdade de Higiene e Saúde Pública da Universidade de São Paulo 1950, 4 (2): 135-83. [Tese de Livre Docência - Faculdade de Higiene e Saúde Pública, Universidade de São Paulo]. 
46. Jordan W. The Austin school health study: dental health. American Journal of Public Health 1962; 52: 301-7.

47. Künzel W. Effect of an interruption in water fluoridation on the caries prevalence of the primary and secondary dentition. Caries Research 1980; 14: 304-10.

48. Lemke CW, Doherty JM, Arra MC. Controlled fluoridation: the dental effects of discontinuation in Antigo, Wisconsin. Journal of the American Dental Association 1970; 80: 782-6.

49. Lichtig J. Especialista condena flúor no abastecimento de água. Folha de S.Paulo 10 mai. 1987; p.A23 [Entrevista - Caderno Cidades].

50. Lima YBO. Dose de risco de fluorose dental a que são submetidas crianças em região de água fluoretada: avaliação do efeito da temperatura ambiental e da exposição a dentifrícios fluoretados. Piracicaba; 2000. [Dissertação de Mestrado - Faculdade de Odontologia de Piracicaba, Universidade Estadual de Campinas].

51. Long JG, Stowe E. Monitoring fluoride in Vermont's drinking water. Journal of Public Health Dentistry 1973; 33: 13-22.

52. Luz AS, Nuto SAS, Vieira APGF. Vigilância sanitária da fluoretação das águas de abastecimento público no município de Fortaleza, Ceará. In: Forte BP, Guedes MVC. Conhecimento e poder em saúde: cultura acadêmica da prática clínica e social aplicada. Fortaleza: PG-DEN-UFC; 1998. p.19-30.

53. Maier FJ. Fluoruración del agua potable. Mexico: Limusa-Wiley; 1971.

54. Manfredini MA. Por que controlar o flúor na água. Diário Popular 20 jan. $1991 ;$ p.6. 
55. Manfredini MA. Vigilância da fluoretação em Santos. Santos: SEHIG; 1995 [relatório técnico].

56. Manfredini MA. Vigilância dos níveis de flúor na água. D.O. Urgente [Diário Oficial do Município de Santos] 26 mar. 1993; p.2.

57. Ministério da Saúde. DATASUS 1991. Disponível no URL:

$<$ http//www.datasus.gov.br> [Informações de Saúde/Abastecimento de água]. Capturado em 3 mai. 2000.

58. Modesto A, Tanaka FHR, Freitas AD, Cury JA. Avaliação da concentração de fluoreto na água de abastecimento público do Município do Rio de Janeiro. Revista Brasileira de Odontologia 1999; 56 (5): 217-21.

59. Montoro AF. Programa de governo. São Paulo: PMDB; 1982.

60. Murray JJ. O uso correto de fluoretos na saúde pública. São Paulo: OMS-Ed.Santos; 1992.

61. Narvai PC, Castellanos RA, Frazão P. Prevalência de cárie em dentes permanentes de escolares do Município de São Paulo, SP, 1970-1996. Revista de Saúde Pública 2000, 34 (2): 196-200.

62. Narvai PC. Cárie dentária e flúor: uma relação do século XX. Ciência e Saúde Coletiva 2000; 5 (2): 381-92.

63. Narvai PC. Cárie dentária: cai prevalência em São Paulo. Jornal da USP 915 dez. 1996a; 374: 2. [Reproduzido no APCD Jornal dez. 1996; (31) 476: 15].

64. Narvai PC. Dentifrícios: vigilância sanitária no Brasil. Boletim SOBRAVIME 1996b; 22: 12. 
65. Narvai PC. Flúor nas águas de São Paulo? Saúde em Debate 1980; 10: 36.

66. Narvai PC. Fluoretação das águas: razões para prosseguir. São Paulo: FUNDAP/SES-SP; 1997.

67. Narvai PC. Parar a fluoretação das águas? Jornal da ASSEMAE nov. 1993; 31: 2 .

68. Narvai PC. Saúde bucal e cidadania. São Paulo: FSP-USP; 1991. 12p. [Apresentado na 1ª Conferência Estadual de Saúde de São Paulo, em 08 de outubro de 1991].

69. Narvai PC. Vigilância sanitária e saúde bucal. São Paulo: FSP-USP; 1998.

70. Nascimento A. Vigilância é tarefa primordial do Estado. Súmula 1998; 68: 1.

71. Neder C. O SUS e o PAS na capital de São Paulo. Ação Coletiva 1998; 1 (3): 11.

72. [OESP] O Estado de S.Paulo. Água vai continuar sem flúor, admite Sabesp. O Estado de S. Paulo 4 set. 1992; p.6 [Caderno Cidades].

73. [OMS] Organización Mundial de la Salud. Fluoruros y salud. Ginebra: OMS; 1972. [Série de Monografias, № 59].

74. [OPS] Organización Panamericana de la Salud. Plan Decenal de Salud para las Américas: Informe final de la III Reunión Especial de Ministros de Salud de las Américas (Santiago, Chile, 2-9 de octubre de 1972). Washington: OPS-OMS; 1973. [Documento Oficial no 118]. 
75. Pinto VG. Revisão sobre o uso e segurança do flúor. RGO 1993; 41 (5): 263-6.

76. Prado IAT, Brevillieri CM, Narvai PC, Schneider DA, Manfredini MA. Estabilidade do flúor em amostras de água. RGO 1992; 40 (3): 197-9.

77. Rio Grande do Sul. Secretaria da Saúde e do Meio Ambiente. Divisão de Vigilância Sanitária. Setor de Vigilância da Qualidade da Água para Consumo Humano. Sistema de vigilância dos teores de flúor nas águas de abastecimento público do Estado do Rio Grande do Sul: Relatório anual do flúor - Ano base 1998. Porto Alegre: SSMA; 1999. [relatório técnico].

78. Roemer R. Water fluoridation: public health responsability and the democratic process. American Journal of Public Health 1965; 55: 1337 41.

79. Sá ENC, Simioni AMC, Ramos CRS e col. Êxodo forçado de servidores da Secretaria Municipal da Saúde de São Paulo em decorrência da implantação do PAS - Plano de Atendimento à Saúde. São Paulo: USPFSP; 1997 [Série Monográfica oㅡ 6 - Eixo Política, Planejamento e Admionistração].

80. Santoro AMCV. Teor de flúor nos chás industrializados no Brasil e seu significado para a saúde bucal. São Paulo; 1997. [Dissertação de Mestrado - Faculdade de Saúde Pública, Universidade de São Paulo].

81. São Paulo (Estado). Assembléia Legislativa. Constituição do Estado de São Paulo de 1989. São Paulo: IMESP; 1999. 
82. São Paulo (Estado). Assembléia Legislativa. Lei Complementar nº 791/95, de 09/03/1995, estabelece o Código de Saúde no Estado. Diário Oficial do Estado de São Paulo 10 mar. 1995; p. 1-5.

83. São Paulo (Estado). Assembléia Legislativa. Lei no 4.687/58, de 18/04/1958. Diário Oficial do Estado de São Paulo 19 abr. 1958; p.56.

84. São Paulo (Estado). Secretaria de Estado da Saúde. Resolução SS-250, de 15/08/1995. Diário Oficial do Estado de São Paulo 16 ago. 1995; seção I, p.11.

85. São Paulo (Estado). Secretaria de Estado da Saúde. Resolução SS-329, de 13/11/1987. Diário Oficial do Estado de São Paulo 14 nov. 1987; seção I, p.12.

86. São Paulo (Estado). Secretaria de Obras e do Meio Ambiente.

Comunicado: 31 outubro de 1985. [Carta aos cirurgiões-dentistas de São Paulo - Anexo 5].

87. São Paulo (Município). Câmara Municipal. Lei Municipal no 11.488 , de 11/03/1994. Diário Oficial do Município de São Paulo 16 mar. 1994; p.7879.

88. São Paulo (Município). Câmara Municipal. Lei Municipal no 12.623, de 06/05/1998. Diário Oficial do Município de São Paulo 13 mai. 1998; p.63.

89. São Paulo (Município). Secretaria da Saúde. Centro de Epidemiologia, Pesquisa e Informação. Sistema Municipal de Vigilância Sanitária da Fluoretação de Águas de Abastecimento Público. Diário Oficial do Município de São Paulo 27 out. 1990; p.15. 
90. São Paulo (Município). Secretaria Municipal da Saúde. Assessoria de Saúde Bucal. Implantação do sistema de vigilância sanitária da fluoretação das águas de abastecimento público no Município de São Paulo. São Paulo: PMSP-SMS; 1989. [relatório técnico].

91. São Paulo (Município). Secretaria Municipal da Saúde. Centro de Epidemiologia, Pesquisa e Informação. Assessoria de Saúde Bucal. Implantação do sistema de vigilância sanitária da fluoretação de águas de abastecimento público no Município de São Paulo: Relatório anual. São Paulo: PMSP-SMS; 1991. [relatório técnico].

92. São Paulo (Município). Secretaria Municipal da Saúde. Centro de Epidemiologia, Pesquisa e Informação. Assessoria de Saúde Bucal. Sistema de vigilância sanitária da fluoretação de águas de abastecimento público no Município de São Paulo: Relatório anual 1991. São Paulo: PMSP-SMS; 1992. [relatório técnico].

93. São Paulo (Município). Secretaria Municipal da Saúde. Centro de Epidemiologia, Pesquisa e Informação. Assessoria de Saúde Bucal. Sistema de vigilância sanitária da fluoretação de águas de abastecimento público no Município de São Paulo: Relatório anual 1992. São Paulo: PMSP-SMS; 1992. [relatório técnico].

94. São Paulo (Município). Secretaria Municipal da Saúde. Centro para Organização da Atenção à Saúde. Centro de Epidemiologia, Pesquisa e Informação. Sistema Municipal de Vigilância Sanitária da Fluoretação de Águas de Abastecimento Público. Relatório Semestral (Jan./Jun. 1993). Diário Oficial do Município de São Paulo 14 set. 1993; p.22-3. 
95. São Paulo (Município). Secretaria Municipal da Saúde. Centro para Organização da Atenção à Saúde. Centro de Epidemiologia, Pesquisa e Informação. Sistema Municipal de Vigilância Sanitária da Fluoretação de Águas de Abastecimento Público. Relatório Quadrimestral (Jul./Out. 1993).

Diário Oficial do Município de São Paulo 8 jan. 1994; p.14.

96. São Paulo (Município). Secretaria Municipal da Saúde. Centro para Organização da Atenção à Saúde. Coordenadoria de Saúde Bucal. Sistema de vigilância sanitária da fluoretação de águas de abastecimento público no Município de São Paulo: Relatório anual 1994. São Paulo: PMSP-SMS; s.d.p. [relatório técnico].

97. São Paulo (Município). Secretaria Municipal da Saúde. Centro para Organização da Atenção à Saúde. Coordenadoria de Saúde Bucal. Sistema de vigilância sanitária da fluoretação de águas de abastecimento público no Município de São Paulo: Relatório anual 1995. São Paulo: PMSP-SMS; s.d.p. [relatório técnico].

98. São Paulo (Município). Secretaria Municipal da Saúde. Centro para Organização da Atenção à Saúde. Coordenadoria de Saúde Bucal. Sistema de vigilância sanitária da fluoretação de águas de abastecimento público no Município de São Paulo: Relatório anual 1996. São Paulo: PMSP-SMS; s.d.p. [relatório técnico].

99. São Paulo (Município). Secretaria Municipal da Saúde. Centro para Organização da Atenção à Saúde. Coordenadoria de Saúde Bucal. Sistema de vigilância sanitária da fluoretação de águas de 
abastecimento público no Município de São Paulo: Relatório anual 1997. São Paulo: PMSP-SMS; 1998. [relatório técnico].

100. São Paulo (Município). Secretaria Municipal da Saúde. Centro para Organização da Atenção à Saúde. Coordenadoria de Saúde Bucal.

Sistema de vigilância sanitária da fluoretação de águas de abastecimento público no Município de São Paulo: Relatório anual 1998. São Paulo: PMSP-SMS; 1999. [relatório técnico].

101. São Paulo (Município). Secretaria Municipal da Saúde. Centro para Organização da Atenção à Saúde. Coordenadoria de Saúde Bucal. Sistema de vigilância sanitária da fluoretação de águas de abastecimento público no Município de São Paulo: Relatório anual 1999. São Paulo: PMSP-SMS; 2000. [relatório técnico].

102. Schneider Filho DA, Prado IT, Narvai PC, Barbosa SR. Fluoretação da água: como fazer a vigilância? Cadernos de Saúde Bucal 2. Rio de Janeiro: Cedros; 1992.

103. Shannon IL. The problem of maintaining the fluoride level in fluoridating the water supply. Texas Dental Journal 1980; 98: 6-8.

104. Silva CAL, Cardoso ACC. Experiência de vigilância da fluoretação de águas para consumo humano baseado no heterocontrole. In: Congresso Brasileiro de Epidemiologia-EPIRIO-98, 4, Rio de Janeiro. Livro de resumos. Rio de Janeiro: ABRASCO; 1998. p.443 [resumo no 0940].

105. [Sindsep] Polêmica em debate sobre o PAS. Jornal do Sindsep jan. $2001 ;$ p.6. 
106. Telesi Junior E. Reflexões sobre a política de saúde do Município de São Paulo (1989-1992). São Paulo; 1998. [Tese de Doutorado — Faculdade de Saúde Pública, Universidade de São Paulo].

107. Uchôa HW, Saliba NA. Prevalência de fluorose dental na cidade de Pereira Barreto. Boletim do Serviço Odontologia Sanitária 1970; 6 (3):11-6.

108. Vasconcellos MCC. Prevalência de cárie dentária em escolares de 7 a 12 anos de idade, na cidade de Araraquara, SP (Brasil), 1979. Revista de Saúde Pública 1982; 16: 317-28.

109. Viegas AR, Viegas $Y$, Fernandez RAC, Rosa AGF. Fluoretação da água de abastecimento público. Revista da APCD 1987; 41 (4): 202-4.

110. Viegas AR. Manual de odontologia sanitária: aspectos preventivos da cárie dentária. São Paulo: Massao Ohno-USP; 1961

111. [WHO] World Health Organization. Fluorides and oral health. Geneva: WHO; 1994. [Technical Report Series, 846].

112. [WHO] World Health Organization. Fluorine and fluorides. Geneva: WHO; 1984. [Environmental Health Criteria, 36]. 